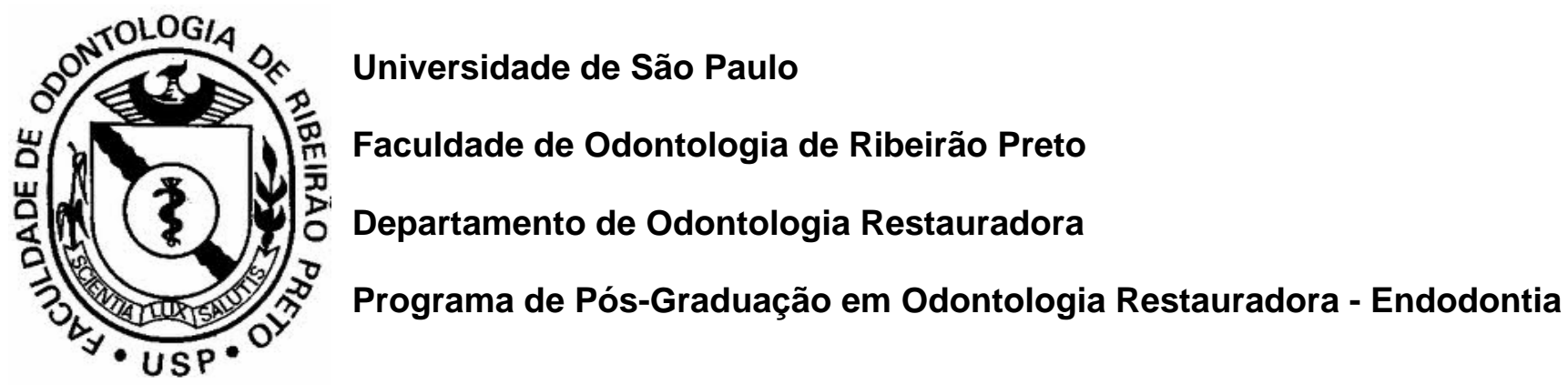

\title{
Avaliação da quantidade de formaldeído liberado por alguns cimentos endodônticos
}

Jose Estevam Vieira Ozorio

Tese de Doutorado apresentada à Faculdade de Odontologia de Ribeirão Preto da Universidade de São Paulo para a obtenção do grau de Doutor em Ciências - Programa Odontologia Restauradora Área de concentração: Odontologia Restauradora (Opção Endodontia). 



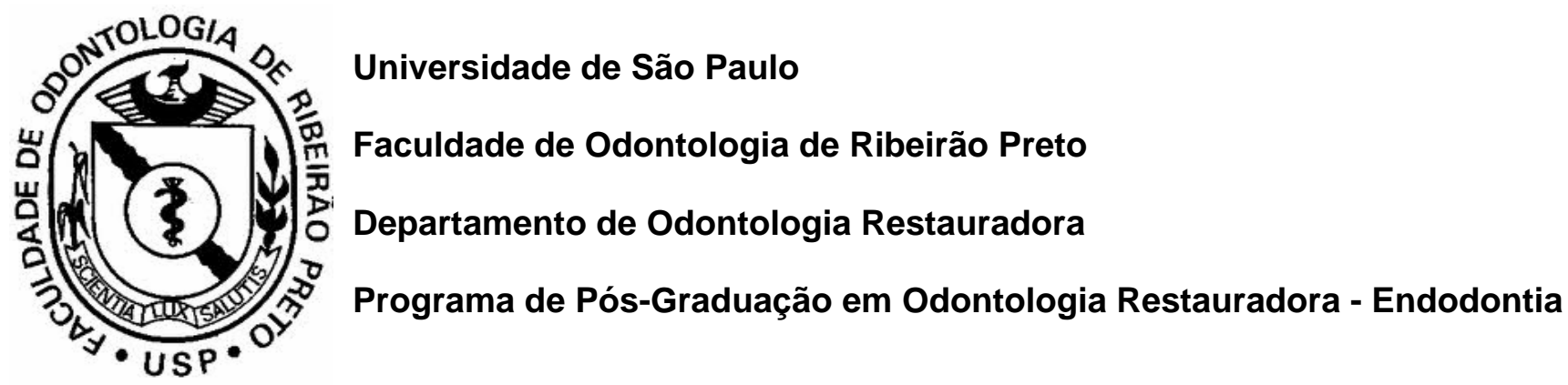

\section{Avaliação da quantidade de formaldeído liberado por alguns cimentos endodônticos}

Jose Estevam Vieira Ozorio

Tese de Doutorado apresentada à Faculdade de Odontologia de Ribeirão Preto da Universidade de São Paulo para a obtenção do grau de Doutor em Ciências - Programa Odontologia Restauradora Área de concentração: Odontologia Restauradora (Opção Endodontia).

Orientador: Prof. Dr. Ricardo Gariba Silva 
Autorizo a reprodução e divulgação total ou parcial deste trabalho, por qualquer meio convencional ou eletrônico, para fins de estudo e pesquisa, desde que citada à fonte.

Assinatura do autor:

Data: / 2010.

\section{FICHA CATALOGRÁFICA}

Ozorio, Jose Estevam Vieira

Avaliação da quantidade de formaldeído liberado por alguns cimentos endodônticos. Ribeirão Preto, 2012.

157p.: il.; $30 \mathrm{~cm}$.

Tese de Doutorado, apresentada à Faculdade de Odontologia de Ribeirão Preto da Universidade de São Paulo (FORP-USP). Área de concentração: Odontologia

Restauradora, subárea Endodontia.

Orientador: Prof. Dr. Ricardo Gariba Silva

1. Formaldeído. 2. Cimentos endodônticos. 3. Espectrofotometria. 

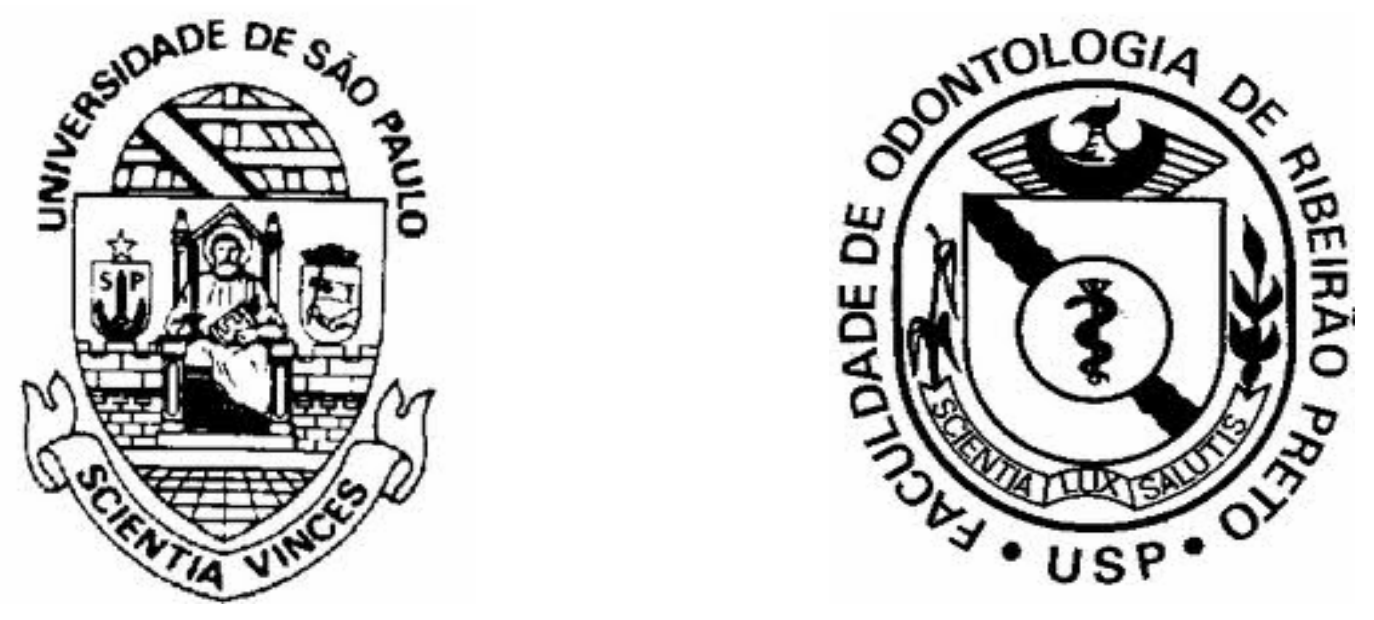

Este trabalho de pesquisa foi realizado no Laboratório de Pesquisa em Endodontia do Departamento de Odontologia Restauradora e no Laboratório de Gerenciamento de Resíduos Odontológicos (LAGRO) da Faculdade de Odontologia de Ribeirão Preto da Universidade de São Paulo. 



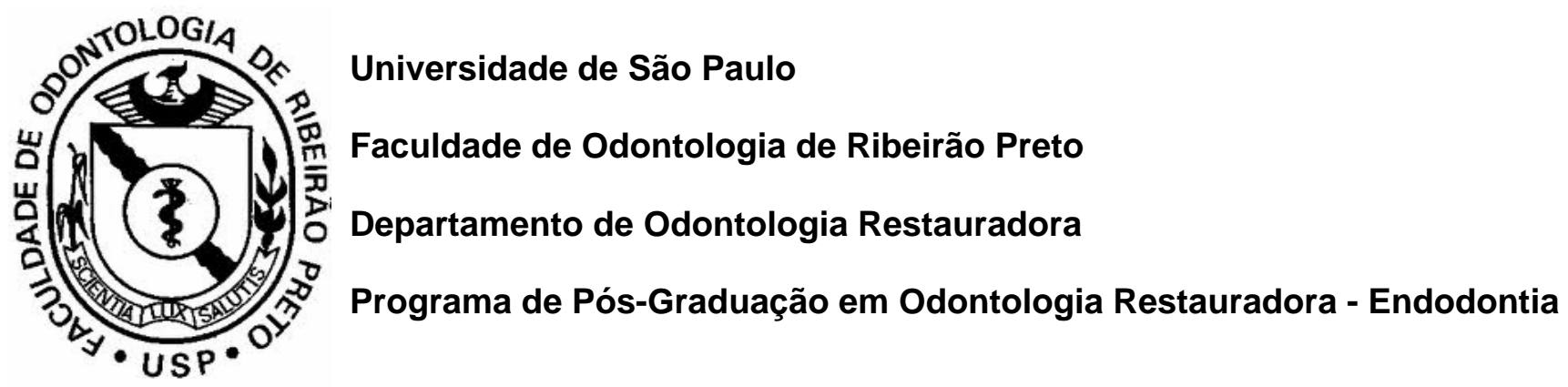

Folha de Aprovação

Membros da Comissão Julgadora da Tese de Doutorado de Jose Estevam Vieira Ozorio, apresentada ao Departamento de Odontologia Restauradora - Endodontia, da Faculdade de Odontologia de Ribeirão Preto, Universidade de São Paulo, I

Comissão Julgadora:

Prof. Dr. Ricardo Gariba Silva (Orientador)

(Nome / Instituição)

(Nome / Instituição)

(Nome / Instituição) 

..."Em determinados momentos a ciência se apresenta pela observação da exatidão de uma verificação experimental. $O$ experimento se traduz pela inteligência do homem que nasce nas faculdades e origina a descoberta para assimilar a verdade"...

Rita de Cássia Rezende 


Dedico este trabalho...

Em especial a minha mãe Angelita Vieira Ribeiro Ozorio, pelas orações, pelo amor que sempre me dedicou abdicando de seus próprios interesses, pelo incentivo na conquista dos meus objetivos, e por todo investimento que se fez necessário para minha formação.

Ao meu irmão Carlos Vicente Vieira Ribeiro Ozorio (in memorian), que sempre esteve comigo, caminhou ao meu lado, me protegendo e me dando coragem para todas as minhas conquistas. 

Agradecimentos 

A Deus pela fiel presença em minha vida, por ter me concedido forças para jamais fraquejar, sem que eu precisasse pedir, saúde para continuar a luta com garra através de seus préstimos no auxílio das minhas escolhas por uma futuro promissor, permanecendo sempre comigo em todos os momentos difíceis.

Ao meu orientador Prof. Dr. Ricardo Gariba Silva, por me dar a direção mediante o ordenamento dos estudos durante o período de construção deste trabalho alicerçados nos moldes da ciência, aliados as suas admiráveis experiências profissionais, bem como pessoais, abraçando-me plenamente de forma paternal, me incentivando todo o tempo para que o desejo pessoal da construção desta obra pudesse se concretizar, além de compartilhar das dificuldades apresentadas no decorrer desta conquista.

Ao Prof. Dr. Jesus Djalma Pécora, por me conceder a oportunidade de caminhar ao seu lado e desfrutar de todo aprendizado da arte de viver mediante seus ensinamentos, pelo incentivo à pesquisa científica na ousadia de dar mais um direcionamento ao mundo, pelas experiências de vida que agregadas deram origem a tamanha sapiência fazendo com que a junção desses valores somasse riquezas ao meu saber, e atuassem de forma integral proporcionando a diferença na criação do presente projeto, e principalmente pela sua amizade, o que desde já torna este agradecimento especial. 


\section{A Reitora da Universidade de Ribeirão Preto - UNAERP, Elmara Lúcia de}

Oliveira Bonini, pelos préstimos de sua sensibilidade a carreira que escolheu abraçar os quais no primeiro momento foram responsáveis pela base sólida da minha primeira formação, pela possibilidade que me concedeu para alçar vôos maiores, promovendo a maior dignidade no seguimento da busca específica por meio da Pós- Graduação em Endodontia, por seu esforço, incentivo, pela confiança depositada em todos os momentos em que busquei sua compreensão. Dessa forma humildemente agradeço com profunda gratidão seu comprometimento, além das orientações que neste atual momento me renderam condições para que eu pudesse chegar até aqui nesta estrada, e que certamente direta, ou indiretamente somados traduzem um valor inenarrável. Muito Obrigada! 
A Prof. ${ }^{a}$ Dr. ${ }^{a}$ Melissa Andréia Marchesan, pela ajuda, pelo incentivo, por sua amizade, pela confiança, e por participar do meu crescimento profissional, com total entusiasmo.

A Prof. ${ }^{a}$ Dr. ${ }^{a}$ Débora Fernandes Costa Gudes, pela amizade, disponibilidade e empenho na elaboração deste trabalho sem poupar qualquer esforço para o êxito da sua conclusão.

Ao Prof. Dr. Manoel Damião de Sousa Neto, por sua amizade desde a minha formação profissional, incentivo, solidariedade, e camaradagem mediante nossa convivência, onde esta união culminou para facilitar a edificação de todo o caminho até a conquista do presente título.

A Prof. ${ }^{a}$ Dr. ${ }^{a}$ Yara Teresinha Corrêa Silva Sousa, por sua compreensão, dedicação pessoal, e entendimento em todos os momentos decisivos os quais permitiram conceber de maneira nítida a realização deste trabalho.

Aos integrantes do corpo docente do programa de Pós-Graduação em Endodontia da Faculdade de Odontologia de Ribeirão Preto da Universidade São Paulo, Prof. Dr. Luiz Pascoal Vansan, Prof. Dr. Antonio Miranda da Cruz Filho, Prof. Dr. Ricardo Novak Savioli, Prof. $^{a}$ Dr. $^{a}$ Isabel Cristina Froner, pelos ensinamentos transmitidos no período de duração deste programa. 
Ao meu amigo José Antonio Brufato Ferraz, que esteve ao meu lado nas horas que sorrir, nas horas em que me lamentei, e nas horas em que de uma forma ou de outra demonstrei total cansaço e desanimo. Hoje quero parar e agradecer pela amizade sincera, pela confiança paternal, pelo sorriso diário, agradeço de peito aberto, e de alma por me permitir desfrutar da essência do seu ser, porque você fez, faz e sempre fará parte não apenas de mais esta realização, mas da minha vida.

A Ana Lúcia Machado de Oliveira Ferraz, pelo inestimável apoio na preparação e elaboração da capa deste trabalho, e pela disponibilidade sempre manifestada pela amizade.

Ao meu amigo Marco Aurélio Versiani, pela nossa alegre e tranqüila convivência, por sua simplicidade de dentro para fora, pelo mais profundo desempenho do papel de ser pai transferindo à sua descendência lições de dignidade e amor. Dessa forma, quero dizer que a melhor referência em crises é que ter bons contatos se torna essencial nos momentos decisivos, onde os sentimentos não precisam de motivos, nem os desejos de razão.

Aos amigos José Antônio Saad Salomão, Alexandre Bonini, e Danilo Alessandro de Oliveira, pela dedicação a nossa amizade, pelo companheirismo e união de todas as horas. Que eu possa retribuir um-a-um o empenho para que eu pudesse realizar mais este sonho profissional. 
Ao Carlos Renato Florentino Rodrigues, que se revelou mais um dentre tantos amigos pela convivência e solidariedade.

A Dr. ${ }^{a}$ Eni Aparecida Lorencete de Oliveira, pela competência e empenho, com total colaboração para que todos os obstáculos pudessem ser superados tornando a realização deste projeto real.

Aos amigos Prof. José Roberto de Freitas, Benedito Sunder Chest, pela generosidade, paciência, e total entendimento da importância deste trabalho, tendo ambos permitidos meu afastamento temporário do exercício das minhas atividades profissionais, garantindo meu retorno ao final.

A Adriana Angeline Palmeira, coordenadora do gabinete da Reitoria da Universidade de Ribeirão Preto - UNAERP, pela atenção e gentileza no tratar, apresentando-se sempre pronta a contribuir com responsabilidade.

As secretarias Marcela Stella Paiva Lucheta, e Maria da Graça Losi Viana, do gabinete da Reitoria da Universidade de Ribeirão Preto - UNAERP, pelo tratamento cordial que sempre me foi atribuído.

Ao saudoso amigo Luiz Marcondes, por sua generosidade, companheirismo, e parceria.

A amiga Fabíola Domenes Sousa, pela boa vontade, amizade, solidariedade, e exemplo de virtude humana que reflete garra e determinação. 
Ao funcionário Reginaldo Santana da Silva, técnico do laboratório de pesquisa em Endodontia da Faculdade de Odontologia de Ribeirão Preto da Universidade São Paulo, por sua amizade e solicitude nas diversas fases contribuindo de forma incondicional, generosa solidariedade, e desprendimento durante a elaboração deste projeto.

Ao funcionário Carlos Feitosa dos Santos, secretário do programa de PósGraduação em Odontologia Restauradora da Faculdade de Odontologia de Ribeirão Preto da Universidade São Paulo, por sua amizade, participação, e contribuição mediante ajuda pessoal, cumprindo todas as normas e obrigações como limites e respeito.

A funcionária Luiza Godoi Pitol, técnica do laboratório de pesquisa em Endodontia da Faculdade de Odontologia de Ribeirão Preto da Universidade São Paulo, por todo convívio, educação e disponibilidade durante o curso.

As funcionárias do Departamento de Odontologia Restauradora da Faculdade de Odontologia de Ribeirão Preto da Universidade São Paulo, Maria Amália Viesti de Oliveira, Maria Isabel Cezário Francisco Miguel, Rosângela Angelini, pelo convívio diário mediante demonstração de carinho e atenção. 
A Patricia Marchi, técnica do laboratório de pesquisa em Dentística da Faculdade de Odontologia de Ribeirão Preto da Universidade São Paulo, pela contribuição, amizade e convivência durante todo o período do curso.

As funcionárias Isabel Cristina Galino Sola e Regiane Cristina Moi Sacilotto, secretárias do setor de Pós-Graduação da Faculdade de Odontologia de Ribeirão Preto da Universidade São Paulo, pela dedicação e orientações concedidas durante o curso.

A CAPES, Coordenação de Aperfeiçoamento de Pessoal de Nível Superior, pela ajuda monetária oferecida que possibilitou a realização deste curso de PósGraduação.

\section{A Faculdade de Odontologia de Ribeirão Preto da Universidade de São} Paulo, nas pessoas de seus diretores, professores, e funcionários, que sempre se mostraram prontos no apoio necessário para o desenvolvimento das atividades de pesquisa que foram determinantes no desenvolvimento do projeto durante todo o período do curso. 

Resumo 

OZORIO, J. E. V. Avaliação da quantidade de formaldeído liberado por alguns cimentos endodônticos, 2012. - 157p. Tese (Doutorado) - Faculdade de Odontologia de Ribeirão Preto, Universidade de São Paulo, Ribeirão Preto, 2012.

Analisou-se, por meio de espectrofotometria, a liberação de formaldeído de cimentos endodônticos à base de óxido de zinco e eugenol, resinas epóxica e polimetacrilato, hidróxido de cálcio e biocerâmico, estudados em diferentes oportunidades: durante a espatulação; decorrido três vezes o tempo de endurecimento e, por fim, na extração de sua massa endurecida. As amostras foram adquiridas pela coleta do volume da água utilizada em cada período e, determinada a curva de calibração da liberação do formaldeído e análise controle com água, foram submetidas à análise colorimétrica com adição dos reagentes: $5,0 \mathrm{~mL}$ de solução tampão, $0,5 \mathrm{~mL}$ de solução de parafenilenodiamina e $2,5 \mathrm{~mL}$ de peróxido de hidrogênio em balões volumétricos de $50,0 \mathrm{~mL}$ mantendo-os em repouso por 20 minutos. Após, foi realizada leitura em espectrofotômetro duplo feixe nos comprimentos de onda 326 , 334 e $462 \mathrm{~nm}$. Detectou-se formaldeído em todos os cimentos à base de resina epóxica, no EndoREZ® e no Endomèthasone N, quantificado apenas no Sealer 26 (7.40 mg.L-1) e Endomèthasone $\mathrm{N}$ (9.13 mg.L-1) durante a espatulação; no $\mathrm{AH}$ Plus $^{\circledR}$ (4.44 mg.L-1) e no Endomèthasone $\mathrm{N}$ (18.14 mg.L-1) durante o endurecimento, e somente no Endomèthasone $\mathrm{N}$ depois de endurecido (9.43 mg.L1). Concluiu-se que, durante a espatulação, todos os cimentos de resina epóxica liberaram formaldeído, com quantificação apenas para o Sealer 26, o Endomèthasone $\mathrm{N}$ apresentou a maior quantidade, e o Endorez liberou a substância em quantidade insuficiente para quantificação. Após a espatulação, todos os de resina epóxica liberaram formaldeído, com quantificação no AH Plus e o Endomèthasone $\mathrm{N}$ apresentou a maior quantidade da substância, que também foi encontrada no Endorez, sem quantificação. Endurecidos, todos os cimentos de resina epóxica e o Endorez liberaram formaldeído em quantidade insuficiente para quantificação, e o cimento Endomèthasone $\mathrm{N}$ liberou a maior quantidade dessa substância.

Descritores: Cimentos endodônticos, Formaldeído, Espectrofotometria, colorimetria. 

Abstract 

OZORIO, J. E. V. Evaluation of the quantity of formaldehyde released by some endodontic sealers, 2012. - 157p. Tese (Doutorado) - Faculdade de Odontologia de Ribeirão Preto, Universidade de São Paulo, Ribeirão Preto, 2012.

This study evaluated, by means of spectrophotometry, the release of formaldehyde in zinc oxide, epoxy resins and polymethylmethacrylate, calcium hydroxide and bioceramic based endodontic sealers in different situations: during mixing; after 3 time the setting time and, at extraction of its hardened mass. The samples were acquired by means of collection of the volume of water used in each period and after determining the calibration curve of formaldehyde release and analyzing the control with water - were submitted to colorimetric analysis with the addition of the following reagents: $5.0 \mathrm{~mL}$ of buffered solution, $0.5 \mathrm{~mL}$ of paraphenylenediamine and $2.5 \mathrm{~mL}$ of hydrogen peroxide to a $50.0 \mathrm{~mL}$ volumetric flask, which was kept at rest for 20 minutes. Double-beam spectrophotometer readings were performed at 326, 334 and $462 \mathrm{~nm}$ wavelengths. Formaldehyde was detected in all epoxy resin based sealers, in EndoREZ and in Endomèthasone N, quantified only in Sealer 26 (7.40 mg.L-1) and Endomèthasone N (9.13 mg.L-1) during mixing, and in AH Plus (4.44 mg.L-1) and Endomèthasone $\mathrm{N}$ (18.14 mg.L-1) during the setting time, and only in Endomèthasone $\mathrm{N}$ after setting (9.43 mg.L-1). It can be concluded that during mixing all epoxy resin based sealers released formaldehyde, with quantification being possible only for Sealer 26, Endomèthasone $\mathrm{N}$ showed higher quantities, and Endorez released the substance in insufficient quantity for detection. After mixing, all epoxy resin based sealers released formaldehyde, whereas quantification was possible for $\mathrm{AH}$ Plus and Endomèthasone $\mathrm{N}$ presented the highest quantity of the substance, that was also found in Endorez, but could not be quantified. When set, all epoxy resin sealers and Endorez released formaldehyde in insufficient quantity for quantification, and Endomèthasone $\mathrm{N}$ released the greater amount of this substance.

Descriptors: Endodontic sealers, formaldehyde, spectrophotometry, colorimetry. 

Abreviaturas 



\begin{tabular}{|c|c|}
\hline abs & Absorbância \\
\hline $\mathrm{Al}$ & Alumínio \\
\hline BIS-GMA & Bisfenol glicidil metacrilato \\
\hline $\mathrm{Ca}$ & Cálcio \\
\hline $\mathrm{Ca}(\mathrm{OH})_{2}$ & Hidróxido de Cálcio \\
\hline $\mathrm{C}_{6} \mathrm{H}_{8} \mathrm{~N}_{2} \cdot 2 \mathrm{HCl}$ & Diidrocloreto de parafenilenodiamina \\
\hline $\mathrm{cm}$ & Centímetro (s) \\
\hline CRCS & Calcibiotic Root Canal Sealer \\
\hline DNA & Ácido Desoxirribonucléico \\
\hline 4-META & 4-Metacriloxietil trimetilico anidrido \\
\hline EBPADMA & Bisfenol A etoxilado dimetacrilato \\
\hline FA & Formaldeído \\
\hline $\mathrm{F}$ & Flúor \\
\hline G & Grama (s) \\
\hline $\mathrm{HCl}$ & Ácido clorídrico \\
\hline HEMA & 2-Hidroxietil metacrilato \\
\hline HMT & Hexametilenotetramina \\
\hline HPLC & Cromatografia líquida de alta eficiência \\
\hline $\mathrm{H} 2 \mathrm{CO}$ & Formaldeído \\
\hline $\mathrm{H}_{2} \mathrm{O}_{2}$ & Peróxido de hidrogênio \\
\hline IARC & International Agency for Research on Cancer \\
\hline INCA & Instituto Nacional do câncer \\
\hline IUPAC & International Union of Pure and Applied Chemistry \\
\hline L & Litro (s) \\
\hline $\mathrm{L} / \mathrm{h}$ & Litro (s) por hora \\
\hline
\end{tabular}




\begin{tabular}{|c|c|}
\hline MEV & Microscopia eletrônica de varredura \\
\hline $\min$. & Minuto (s) \\
\hline $\mathrm{mol} . \mathrm{L}-1$ & Mol por litro \\
\hline$m g \cdot L-1$ & Miligrama (s) por litro \\
\hline $\mathrm{mg} / \mathrm{L}$ & Miligrama (s) por litro \\
\hline $\mathrm{mL}$ & Mililitro (s) \\
\hline $\mathrm{mm}$ & Milímetro (s) \\
\hline $\mathrm{MPa}$ & Megapascal \\
\hline $\mathrm{NaOH}$ & Hidróxido de sódio \\
\hline $\mathrm{NIOSH}$ & National Institute for Occupational Safety and Health \\
\hline $\mathrm{nm}$ & Nanômetro (s) \\
\hline$\mu \mathrm{L}$ & Microlitro (s) \\
\hline$\mu \mathrm{m}$ & Micrometro \\
\hline OSHA & Occupational Health and Safety Assessment Services \\
\hline P.A. & Pureza analítica \\
\hline $\mathrm{pH}$ & Potencial Hidrogeniônico \\
\hline ppm & Partes por milhão \\
\hline $\mathrm{SnCl}_{2}$ & Cloreto de estanho \\
\hline${ }^{\circ} \mathrm{C}$ & Grau Celsius \\
\hline$\%$ & Por cento \\
\hline$\lambda$ & Comprimento de onda \\
\hline UDMA & Uretano dimetacrilato \\
\hline UV/Vis & Ultra violeta visível \\
\hline $\mathrm{ZnO}$ & Óxido de zinco \\
\hline
\end{tabular}




\section{Lista de Figuras}



Figura 1. (A) Espatulação do cimento em câmara de fibra contendo recipientes; (B) Detalhe do vidro (seta em A) contendo água deionizada

Figura 2. (A) Recipiente plástico com $10 \mathrm{~mL}$ de água deionizada contendo cimento em disco de teflon suspensos; (B) Cimentos em frascos com $10 \mathrm{~mL}$ de água deionizada mantidos em cuba ultrassônica por quinze minutos..

Figura 3. Curva de calibração para formaldeído $(\lambda=326$ e $462 \mathrm{~nm})$

Figura 4. Regressão linear para os comprimentos de onda $(\lambda)$ de $326 \mathrm{~nm}(\mathrm{~A})$ e $462 \mathrm{~nm}(\mathrm{~B})$.

Figura 5. Curva de calibração para formaldeído $(\lambda=334 \mathrm{~nm})$..............................115

Figura 6. Regressão linear para o comprimento de onda indicado

Figura 7. Processo de reação oxidativa catalisada pelo formaldeído: (A) início da reação; (B) após 10 minutos do início da reação; (C) após 20 minutos do início da reação.

Figura 8. Análise espectrofotométrica. (A) Cubeta de quartzo com solução para leitura; (B) Espectrofotômetro UV-VIS duplo feixe com varredura para análise das soluções

Figura 9. Espectrofotometria das soluções testadas para a extração do formaldeído

Figura 10. Espectrograma do cimento endodôntico AH Plus e ampliação apresentando a localização do pico referente ao formaldeído

Figura 11. Espectrograma do cimento endodôntico Sealer 26 nos três momentos analisados

Figura 12. Espectrograma do cimento endodôntico ThermaSeal Plus nos três momentos analisados

Figura 13. Espectrograma do cimento endodôntico MetaSeal nos três momentos analisados

Figura 14. Espectrograma do cimento endodôntico Epiphany nos três momentos analisados

Figura 15. Espectrograma do cimento endodôntico EndoREZ nos três momentos analisados

Figura 16. Espectrograma do cimento endodôntico Apexit Plus nos três momentos analisados

Figura 17. Espectrograma do cimento endodôntico Sealapex nos três momentos analisados 
Figura 18. Espectrograma do cimento endodôntico MTA Fillapex nos três momentos analisados

Figura 19. Espectrograma do cimento endodôntico Endofill nos três momentos analisados.

Figura 20. Espectrograma do cimento endodôntico CRCS nos três momentos analisados.

Figura 21. Espectrograma do cimento endodôntico Pulp Canal Sealer nos três momentos analisados

Figura 22. Espectrograma do cimento endodôntico Endomèthasone $\mathrm{N}$ nos três momentos analisados.

Figura 23. Espectrograma do cimento endodôntico BC Sealer nos três momentos analisados

Figura 24. Aminas utilizadas na cura dos cimentos endodônticos Therma Seal e AH Plus. 


\section{Lista de Tabelas}



Tabela I. Reagentes utilizados no trabalho apresentavam grau de pureza

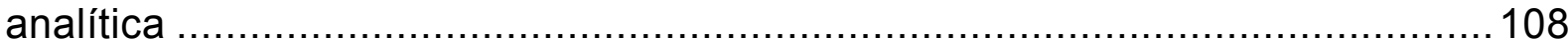

Tabela II. Composição dos cimentos endodônticos …………………………....110

Tabela III. Grupos de cimentos ......................................................................... 121

Tabela IV. Quadro de resumo com o teor de formaldeído encontrado nos cimentos analisados. Dados em mg.L-1 ...........................................................131 

Sumário (2) 

IV - Materiais e Métodos 105

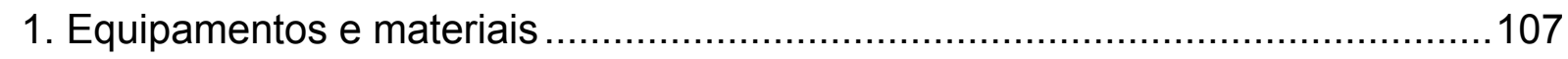

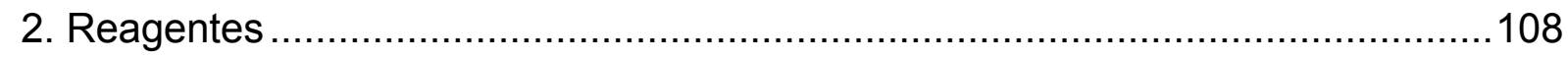

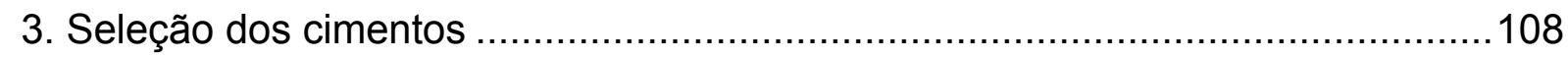

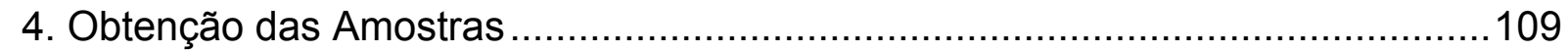

5. Preparo das soluções utilizadas na determinação do formaldeído .....................112

6. Determinação da Curva de Calibração de Formaldeído ....................................113

7. Metodologia Empregada para a Detecção de Formaldeído ..............................115

V - Resultados

1. Capacidade de coleta das amostras de formaldeído no sistema proposto .........121

2. Análises da liberação de formaldeído .....................................................122

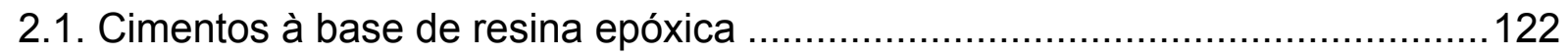

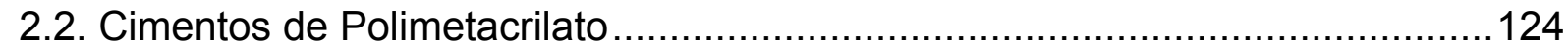

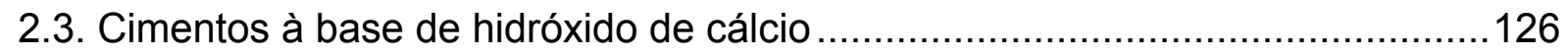

2.4. Cimentos à base de óxido de zinco e eugenol ..........................................128

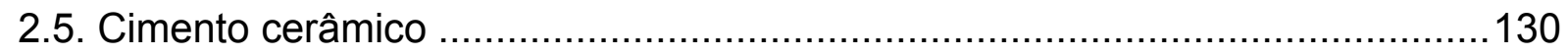

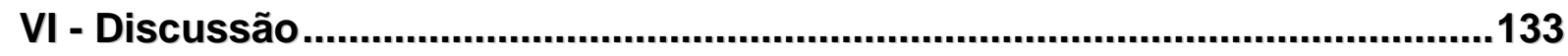

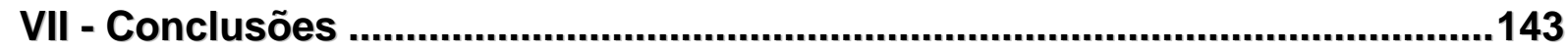

VIII - Referências Bibliográficas...............................................................147 



\section{I - Introdução}



A busca do hermetismo da obturação dos canais radiculares é objetivo perseguido durante a realização do tratamento endodôntico. Obturar um canal radicular significa preenchê-lo em toda a sua extensão com um material inerte e antisséptico, obtendo assim, o preenchimento mais hermético possível daquele espaço, bloqueando a comunicação entre a parte interna e a externa do canal, de modo a não interferir e, se possível, estimular o processo de reparo apical e periapical, que deve ocorrer após a terapia endodôntica radical (ØRSTAVIK et al., 2001; WHITWORTH, 2005; SCHILDER, 2006; ARI et al., 2010).

Rotineiramente, usam-se associações de materiais para a composição da massa obturadora dos canais radiculares, composta basicamente da associação da guta-percha, sob a forma de cones ou plastificada, com um cimento (JAINAEN et al., 2007; SOUZA et al. 2009), que promove a união entre os cones de guta-percha entre si e destes com a dentina, de modo a compor um elenco permanente da configuração interna do sistema de canais radiculares (SCHILDER, 1967; WHITWORTH, 2005 ).

Os cimentos endodônticos, independentemente do tipo, devem preencher determinadas propriedades físico-químicas, que os qualificam para o uso a que se destina, a saber: fácil introdução no canal radicular, selar hermeticamente, não contraírem, impermeáveis à umidade, bacteriostáticos ou impróprios ao crescimento microbiano, radiopacos, não descolorirem a estrutura dentária, estéreis ou passíveis de serem esterilizado, não serem irritantes aos tecidos periapicais e serem de fácil remoção quando se fizer necessário (GROSSMAN, 1988; LEE, 2002; WU et al., 2006; GATEWOOD, 2007; KIM, 2010).

Porém sabe-se que nenhum material obturador, aqui incluídos os cimentos, atende completamente todos os requisitos físico-químicos e biológicos para ser 
52 | Introdução

considerado um material obturador ideal (ØRSTAVIK et al., 2001), o que faz com que se realizem estudos com a finalidade de se encontrarem materiais que vedem o canal radicular da melhor maneira possível (SCHWARTZ, 2006) e atendam aos padrões de obturação, já que a eficácia do tratamento é dependente do selamento tridimensional do canal radicular (PAWIŃSKA et al., 2011).

De acordo com seu principal componente, os cimentos endodônticos são alocados em diferentes grupos, como por exemplo, aqueles que contêm hidróxido de cálcio, resina epóxi, e óxido de zinco e eugenol (BERNÁTH; SZABÓ, 2003; HUANG at al., 2008).

As propriedades físico-químicas dos cimentos endodônticos são estudadas a fim de verificar seus comportamentos no contexto da obturação (BOUILLAGUET et al. 2004, JACK; GOODELL 2008, KOAGEL et al. 2008 ), uma vez que a eluição das suas substâncias ou produtos de degradação ou corrosão pode fazer com que atinjam os tecidos circundantes (ligamento periodontal, osso alveolar) através de numerosas conexões, como, por exemplo, os túbulos dentinários, canais acessórios, canais laterais e forame apical (MJÖR; PINDBORG, 1973; DE DEUS, 1975; DONGARI; LAMBRIANIDIS, 1988; SCHMALZ, et al., 2000; KOCH, 2003), podendo provocar alterações periapicais irritantes ou efeitos adversos (MURPHY, 1988; WALTIMO et al., 2001; GIOVANNI, 2011), o que faz da biocompatibilidade desses materiais uma característica importante.

A biocompatibilidade de um material endodôntico é caracterizada por muitos parâmetros, como citotoxicidade, enotoxicidade, mutagenicidade e carcinogenicidade (AL-HIYASAT, 2010), já que materiais citotóxicos e qualquer material cancerígeno podem causar alterações no DNA, que levam à transformação celular maligna (BERTRAM, 2000). 
Logo, para minimizar a incidência de efeitos colaterais locais e / ou sistêmica, a biocompatibilidade de todos os materiais endodônticos deve ser investigada por meio de testes in vitro e in vivo, determinando se ocorre mutagenicidade, citotoxicidade e efeitos antibacterianos, antes da aplicação clínica (GEURTSEN; LEYHAUSEN, 1997). Os materiais endodônticos com forte atividade antimicrobiana são freqüentemente mutagênicos, principalmente aqueles que liberam formaldeído, em particular aqueles à base de óxido de zinco e eugenol, tais como Endomèthasone e N2 (GEURTSEN; LEYHAUSEN, 1997).

O formaldeído é um dos mais comuns e conhecidos produtos químicos de uso atual. É um aldeído simples de fórmula molecular $\mathrm{H}_{2} \mathrm{CO}$, também é chamado de aldeído fórmico, metanal ou metil aldeído. Pelas regras da IUPAC, deve ser chamado de metanal (PERUZZO; CANTO, 1998). Em solução aquosa é denominado formol ou formalina, comercializado na porcentagem de 37 a $40 \%$ de formaldeído e 10 a $15 \%$ de metanol (PONGSAVEE, 2011). O metanol é adicionado para a estabilização da solução, uma vez que aldeídos em meio aquoso tendem a se polimerizar (VOGEL, 1971, ALLINGER et al., 1978). Como polímero sólido, é denominado paraformaldeído, contendo $91 \%$ a $99 \%$ de formaldeído. Mundialmente produzido e utilizado em inúmeras aplicações que vão de produção de resinas a medicamentos e devido às suas propriedades sensibilizantes e aos seus efeitos irritantes, estudos experimentais em humanos e animais demonstraram que 0 formaldeído inalado provoca genotoxicidade, toxicidade e câncer (COSTA, 2011).

$\mathrm{Na}$ Odontologia, o primeiro relato da utilização do formaldeído para desinfecção de inflamações pulpares foi primeiramente feito por Lepkowski, em 1897. Era uma técnica que causava dor intolerável. Porém não durou até 1904, 
quando Buckley introduziu uma fórmula modificada indicada como antisséptico e mais aceitável clinicamente (VERCO, 1985).

A ação do formaldeído sobre os tecidos periapicais confirmou a ocorrência de efeitos extremamente citotóxicos dessa substância quando presente em cimentos obturadores (FORD, 1985; SPANGBERG et al., 1993; HUANG, 2005; ØRSTAVIK, 2005). A natureza e o grau da reação tecidual estão relacionados com o tipo e a quantidade de cimento, eventual extrusão do material e sua e a condição dos tecidos periodontais (HO et al., 2007; AMILA BRKIĆ, 2009). Há relatos de parestesia do nervo mandibular atribuída à liberação da substância (KOCH et al., 2001) e de ocorrência de reação alérgica (KOCH et al., 2001). BINGHAM et al., E.; Cohrssen, B.; Powell, C.H.; Patty's Toxicology Volumes 1-9 5th ed. John Wiley \& Sons. New York, N.Y. (2001)., p. 5:987

Essa substância pode entrar na circulação sistêmica de pessoas a ela expostas (ZHANG et al., 2010). É altamente reativa, causa irritação dos tecidos e danos em contato, não requer biotransformação e é rapidamente oxidada e incorporada a macromoléculas biológicas sendo excretada pela urina (CONAWAY et al, 1996;. FRANKS, 2005). Os efeitos em humanos, dependendo da concentração do produto químico e o tempo a que fica a pessoa exposta, incluem irritação na região dos olhos, nariz, garganta, pele, dermatite alérgica de contato, alterações histopatológicas da mucosa nasal, asma ocupacional, redução da função pulmonar, resposta imune alterada (IARC, 2006). Há ainda efeitos neurocomportamentais, como cefaléia, tonturas, náuseas, perda de memória e problemas de sono, ocorrem (BINGHAM et al., 2001) danos à mucosa nasal, tais como metaplasia e displasia de células escamosas (ORSIÈRE et al., 2006). 
Existem associações entre a exposição ao formaldeído e o risco ao câncer em vários locais, incluindo cérebro, pulmão e pâncreas (PONGSAVEE, 2011), leucemia predominantemente aguda, leucemia mielóide (GOLDSTEIN, 2010). Isso fez com que a Agência Internacional de Pesquisa ao Câncer (IARC), em 2005, mudasse a classificação do formaldeído do Grupo 2 - provavelmente cancerígeno para os seres humanos - para o Grupo 1 - cancerígenos para seres humanos (IARC 2006).

Todo esse conjunto de aspectos negativos fez com que, em 1998, a American Association of Endodontists não recomendasse o uso do paraformaldeído. Não obstante a sobredita recomendação, a presença de formaldeído foi constatada nos cimentos à base de óxido de zinco e eugenol e nos cimentos resinosos, como os da série AH (AL-HIYASAT et al., 2010).

Espera-se, pois, que novas formulações dos cimentos endodônticos, independente da sua base, apresentem-se desprovidas de substâncias que sejam ameaça para a saúde humana (SPANGBERG et al., 1993; KOCH, 1999; KOCH et al., 2001; KIM, 2010).

Apesar de a literatura relatar trabalhos nesta área de conhecimento, existe grande quantidade de materiais atualmente comercializados e que devem ser testados para avaliar a presença de formaldeído na sua composição, bem como se esse produto químico é liberado em decorrência de eventuais reações químicas que possam ocorrer entre as suas substâncias componentes durante suas espatulações, endurecimento, e até mesmo depois do seu endurecimento final. 
56 | Introdução 
II - Retrospectiva da Literatura 

BAILEY; RANKIN (1971) propuseram método para determinação de formaldeído baseado no efeito dessa substância sobre a oxidação do peróxido de hidrogênio de parafenilenodiamina. Esse efeito foi anteriormente descrito e empregado como um método qualitativo para a detecção de vestígios de formaldeído. O efeito de formaldeído na reação de oxidação é duplo. Primeiro, o produto da reação na presença de formaldeído é um sombrio e complexo. Segundo, a reação acontece em um ritmo muito acelerado. De acordo com os pesquisadores o efeito global é a rápida formação de um produto cuja absorbância reflete a quantidade de formaldeído originalmente presente na mistura. As investigações descritas no trabalho mostraram a reação ser aplicável à determinação quantitativa de formaldeído em baixas concentrações no ar com um grau relativamente elevado de seletividade.

SWEMBERG et al. (1980), induziram por inalação ao vapor de formaldeído nas seguintes ppm $(0,2,6$ ou 15) durante 6 horas ao dia, 5 dias por semana, no período total entre 18 e 24 meses, 240 ratos, sendo 120 do gênero masculino e 120 do gênero feminino. Observou-se o desenvolvimento de carcinoma escamoso em 36 ratos expostos a $15 \mathrm{ppm}$ do vapor de formaldeído, com metástase para ao tecido subcutâneo da pré-maxila. Tumores semelhantes foram observados em ratos expostos ao período de 18 meses em 2, 6 ou 15 ppm de formaldeído. Rinites, displasias epiteliais e metaplasias escamosas ocorreram em todos os ratos expostos ao formaldeído na pesquisa.

PITT FORD (1985) estudo a resposta tecidual em dentes obturados com cimentos que continham formaldeído em sua composição, o N2 e Endomèthasone o cimento Tubliseal foi utilizado como controle. Atuando-se em seis dentes de cada dois cães, estes tiveram suas polpas extirpadas, os canais alargados e irrigados 
com solução salina, logo secos com cones de papel e imediatamente obturados. Dez dentes foram obturados com Endomèthasone, oito com N2 e oito dentes com Tubliseal. Durante tempo de preparação histológica, dois dentes obturados com Endomèthasone e um com N2 foram perdidos. Após análise, observado-se reação periapical inflamatória comum a todos os casos, sendo a mais severa para o Tubliseal e menos severa para Endomèthasone. Em conclusão, o autor relatou que ocorreu anquilose em um dente obturado com Endomèthasone e em todos que foram obturados com N2, não sendo este um material seguro.

MURPHY (1988) afirmou que os objetivos do tratamento de canal são controlar e erradicar a infecção, para preservar a vitalidade dos tecidos periapicais e selar o canal próximo ao ápice do dente, porém mesmo sob condições ideais, os tecidos periapicais pode sofrer alterações após a endodontia. É difícil saber se essas alterações são devidas aos materiais endodônticos empregados, instrumentação durante a preparação do canal, presença residual de organismos a partir de uma polpa infectada, ou uma série de variáveis. O autor relatou que definir um método experimental para a avaliação dos cimentos apresenta uma grande dificuldade por causa da grande variedade de citotoxicidade entre os materiais endodônticos comumente utilizados.

DONGARI (1988) afirmou que os túbulos dentinários são permeáveis e quando expostos podem servir de caminhos transmissíveis entre a polpa e ligamento periodontal. Exposição de dentina radicular pode ocorrer sob seguintes circunstâncias: 1) Em 5 a $10 \%$ de dentes humanos o cemento e esmalte não se juntam. Essa ausência congênita do cemento na junção amelocementária torna cerca de 15.000 túbulos dentinários expostos por $2 \mathrm{~mm}$ na superfície externa da raiz; 2) Ambos cementos, celular e acelular, são tão permeáveis que a difusão de 
corantes a partir da polpa e da superfície externa da raiz é possível. Em algumas áreas do cemento celular os canalículos são contíguos com os túbulos dentinários e assim, o cemento atua como um mediador positivo na comunicação entre os túbulos e o ligamento periodontal; 3) O cemento celular é menos mineralizado que o acelular e pode se formar com fissuras e áreas de hipocalcificação. Esses defeitos estruturais tornam-se mais vulneráveis a irritações externas aumentando a possibilidade de exposição dos túbulos; 4) Lesões traumáticas do cemento tais como fraturas extensas também podem estabelecer comunicação com os túbulos dentinários. Endotoxinas são encontradas dentro dos defeitos originários da perda de integridade entre o cemento e da dentina ao nível da junção cemento-dentinária e foi provado ser mais tóxico do que a endotoxina originária da $\mathrm{E}$. coli. O autor concluiu que a presença de uma endotoxina de alta toxicidade em um local de exposição tubular promover-se-ia o envolvimento pulpar.

KUMPF; DAMEWOOD (1989) realizaram estudo de interação entre formaldeído e água, onde foi utilizada uma variedade de importantes configurações para descrição da interação das substâncias. Os autores incluíram à estas configurações geometrias de estudos relatados anteriormente a fim de permitir comparação crítica aos atuais métodos computacionais utilizados. Os dados obtidos na pesquisa em relação ao potencial de energia de hipersuperfície da água ao formaldeído permitiram aos autores concluírem que ocorre potente interação entre as substâncias.

SPANGBERG et al.(1993) realizam um estudo com o objetivo de verificar a presença de formaldeído no $\mathrm{AH} 26$ e o possível papel do hexametilenotetramina como uma fonte de formaldeído e comparar os resultados de pesquisas similares do N2. Os resultados mostraram que o N2 mostra grande quantidade de moléculas de 
formaldeído na amostra de material recém manipulado durante dois dias. Aos sete dias a concentração baixou para aproximadamente um quinto da concentração inicial. O pó e a resina do AH 26 não contêm formaldeído. Após a manipulação, no entanto, pode ser verificado o aparecimento da substância, durante os dois primeiros dias. A concentração decresce até o sétimo dia. Assim, o autor recomenda que o N2 seja rejeitado como uma escolha de material obturador, não devido aos riscos que pode causar à saúde, mas devido às injúrias causadas pelo formaldeído que ele contém.

NGUYEN (1994) segundo o autor, o cimento N2 pode ser considerado uma pasta. Teve sua composição e o nome modificados várias vezes, podendo ser encontrado na literatura com os seguintes nomes: R-C, RC2B, RET-B. Em 1962 a companhia distribuidora do N2 (AGSA) solicitou à Administração de Drogas e Alimentos a aceitação de um novo N2. O pedido foi negado e a AGSA retirou o pedido em junho de 1967. O Conselho de Terapêutica Dental da Associação Dental Americana também classificou o N2 como inaceitável. A discussão dá-se pela alta concentração de paraformaldeído, considerado uma substância altamente irritante, sendo irritante aos tecidos periapicais. O pó é basicamente óxido de zinco, em quase $70 \%$, mas apresentam em quantidades pequenas, outros componentes como sulfato de bário, tetraóxido de chumbo, paraformaldeído, dióxido de titânio, subnitrato de bismuto, borato de fenil mercúrio, subcarbonato de bismuto, prednisolona e hidrocortisona. O líquido é composto de eugenol e essências de rosa.

CONAWAY et al. (1996) estudou o mecanismo e o risco do folmaldeído por meio da exposição de ratos ao ar contaminado com folmadeído. O mecanismo do 
formaldeído na indução do tumor envolve o formação de ligações cruzadas no DNA e proliferação celular maior secundariamente à citotoxicidade.

GEURTSEN; LEYHAUSEN (1997) investigaram, por meio de revisão de literatura, a respeito da mutagenicidade e genotoxicidade de vários materiais de preenchimento do canal radicular, apoiado em considerações que, além dos benefícios que esses materiais possuem eles também podem proporcionar propriedades indesejáveis podendo representar uma ameaça para a saúde humana. Uma série de relatos mostrou que o paraformaldeído contido em cimentos de óxido de zinco e eugenol, em particular, como Endomethasone e N2, eram antibacterianos. Por outro lado, verificou-se que os materiais endodônticos com forte atividade antimicrobiana eram freqüentemente mutagênicos, ou seja, principalmente aqueles que liberavam formaldeído. Em conclusão os autores afirmam que, os cimentos com baixa biocompatibilidade, como os que liberam formaldeído, não devem ser utilizados, pois, existem alternativas mais seguras.

COHEN et al. (1998) realizaram pesquisa com o objetivo de mensurar a quantidade de formaldeído liberado por três tipos de cimentos endodônticos (AH Plus, EZ-fill e AH 26). A liberação de formaldeído foi analisada, usando HPCL, que pode detectar quantidade igual a 0,25 ppm. O sistema de duas pastas do AH Plus propiciou a menor quantidade de liberação de formaldeído, seguido pelo EZ-Fill. Ambos os cimentos (EZ-Fill e $A H$ 26) são baseados em mistura pó e líquido. Os autores acreditam que a diminuta liberação de formaldeído propiciada pelo AH Plus permite o seu uso como cimento endodôntico.

AMERICAN ASSOCIATION OF ENDODONTISTS (AAE) (1998) posicionou-se em relato que dedicado-se à manutenção da mais alta qualidade de cuidados na prática da endodontia. Como parte do que a dedicação, a AAE apóia ativamente o 
uso de materiais seguros e eficazes em relação ao tratamento do canal radicular. A AAE reconhece que as diferenças legítimas de opinião profissional pode existir como o "mais seguro" ou "mais eficaz" material para um paciente específico ou circunstâncias específicas. Em reconhecimento dessas diferenças legítimas de opinião profissional, a AAE não endossa o uso de materiais específicos. No entanto, a AAE não recomenda o uso de materiais que contém paraformaldeído, devido eles provarem ser tanto inseguros e ineficazes.

KOCH (1999) estudou sobre a liberação de formaldeído de três diferentes cimentos endodônticos: uma resina fenólica, uma resina epóxica e um cimento de óxido de zinco e eugenol contendo paraformaldeído. A presença de formaldeído foi mensurada logo após a manipulação do cimento e após dois tempos de envelhecimento de dois dias e de duas semanas. Também foi avaliado o efeito de diferentes tamanhos das amostras. A análise foi realizada através da reação do formaldeído com acetilacetona e amônia. Os resultados mostraram que é difícil definir um padrão de teste in vitro que possa ser aplicado universalmente para a definitiva determinação de liberação de formaldeído de cimentos endodônticos. O autor também conclui que é difícil uma previsão da liberação de formaldeído in vivo, a partir dos cimentos endodônticos.

LEYHAUSEN et al. (1999) em estudos prévios in vitro e in vivo relataram que o cimento $\mathrm{AH} 26$, à base de resina epóxica pode ser genotóxico e citotóxico. $\mathrm{O}$ estudo determinar os efeitos de citoxicidade e genotoxicidade do cimento AH Plus, por meio de teste de inibição de crescimento com fibroblastos do ligamento periodontal de humanos e teste de vapores alcalinos in vivo. Os testes de Ames foram realizados com extratos de $\mathrm{AH}$ Plus. O material causou ausência ou pequena injúria celular. Além disso, foi verificada ausência de genotoxidade e mutagenicidade 
promovida pelo AH Plus. Os autores orientaram que esses dados devem ser levados em consideração, quando da escolha do cimento endodôntico.

ERSEV et al. (1999) realizaram estudo in vitro com com a finalidade de determinar os efeitos citotóxicos e mutagênicos de cimentos endodônticos nas mais variadas composições químicas. O material manipulado foi deixado, por 24 horas e por uma semana, imersa em meio de cultura de células (teste de citotoxicidade) e em solução fisiológica salina ou dimetil sulfóxido (teste de mutagenicidade). As diferenças entre os valores citotóxicos do cimento endodôntico em células L-929 foram quantificadas colorimetricamente (Teste MTT). Os resultados mostraram que o Tubli Seal, Endométhasone N, CRCS e Ketac Endo não foram mutagênicos no Teste Ames. Misturas de cimento AH 26 sem prata, nos dois tempos testados, foram ligeiramente mutagênicas para as Salmonellas typhimurium TA100. Esses resultados apontam para a possibilidade de que o cimento manipulado $\mathrm{AH} 26$ livre de prata possa conter pequenas quantidades de duas substâncias também consideradas mutagênicas: o Éter Diglicicil Bis-fenol A e o formaldeído.

LEONARDO et al. (1999) investigaram a liberação de formaldeído nos cimentos endodônticos Endométhasone, o AH Plus e o Top Seal. Foi utilizada espectroscopia eletrônica e infravermelho para determinar o conteúdo de formaldeído após o endurecimento do material. Os resultados demonstraram que o Endomèthasone liberou formaldeído em maiores quantidades. Os autores concluíram que o AH Plus e o Top Seal têm composição química similar e liberam formaldeído em concentração mínima.

WILLEMSEN; SIERS (1999) relataram que na odontologia o uso do formaldeído tem sido discutido por anos, e questionaram quais os produtos odontológicos que o contém e a possibilidade que eles possam ter em apresentar 
efeitos sistêmicos. Também relataram as indicações para o uso do produto e as alternativas. Concluíram que boas alternativas para o uso do produto são disponíveis.

HUANG et al. (2000) estudaram cimentos endodônticos AH26 e AHPlus no que tange a liberação/vazamento de lacato desidrogenase (LDH) em hepatócitos de ratos. Os cimentos obturadores foram misturados e dissolvidos em dimetilsulfoxido nas concentrações finais de 0,01, 0,04 \%, e 0,1 \% (peso/vol) com dimetilsulfoxido na concentração de $0,05 \%$. A dose dependente e o tempo denpendente foram mensurados e realizou-se análise da citotoxidade, com ANOVA. Os resultados mostraram que AH26 e AHPlus são tóxicos aos hepatócitos de ratos, com o $\mathrm{AH} 26$ com maior toxicidade que o AHplus. Os autores, ainda concluem, que apesar toxicidade, os cimentos estudados apresentam boas propriedades antimicrobianas.

HAÏKEL et al. (2000) relataram um caso clínico de choque anafilático durante o tratamento endodôntico em paciente de 41 anos de idade cronológica, alérgico ao formaldeído. Nos exames clínicos, foi observado testes cutâneos positivos e elevado nível de imunoblobulina $E$. Os autores salientam que não é frequente tal manifestação durante o procedimento endodôntico, entretanto, enfoca atenção as manifestações patológicas associadas ao formaldeído, bem como sua prevenção na Odontologia.

BERTRAM (2000) em seu trabalho afirmou que mutações espontâneas no DNA podem ocorrer diretamente como conseqüência de erros na sua duplicação ou indiretamente como conseqüência de danos de agentes químicos. A reação química mais freqüente originária do dano no DNA pode ser caracterizada como um ataque eletrofílico em cima de um nucleófilo, em escala mais significante à guanina. Um exemplo de agente químico carcinógeno é a dimetilnitrosamina, solvente químico 
amplamente utilizado. $\mathrm{O}$ autor verificou que as nitrosaminas poderiam ser formadas no ambiente ácido do estômago após a ingestão de aminas primárias ou secundárias utilizadas como agentes de conservação em alimentos e relacionou-as com o aparecimento de câncer gástrico.

$\mathrm{KOCH}$ et al. (2001) analisaram in vitro a liberação de formaldeído de cimentos endodônticos endurecidos. Dez embalagens de AH 26, Amabarut e N2 foram mantidas em ambiente seco, por seis meses. Foi obtida uma quantia de 100 a 200 mg de cada amostra, por meio do desgaste feito com broca esférica. Essa quantidade de material foi armazenada em água destilada. A concentração do formaldeído imersa em água foi aferida por cromatografia de alta tecnologia para exame em líquido. A média de liberação de formaldeído por mg foi de: $6,6( \pm 2,5) \mu \mathrm{g}$

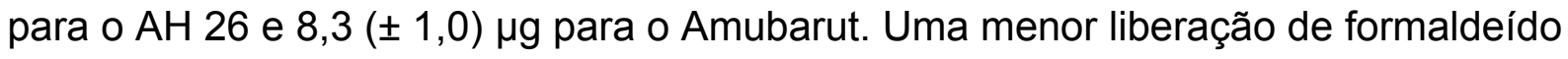
foi detectada nas amostras de N2. Os autores concluíram que a liberação de formaldeído de cimento manipulado é baixa, embora não esteja excluída a possibilidade de uma reação alérgica em pacientes sensíveis.

WALTIMO et al. (2001) compararam três diferentes cimentos utilizados na terapia endodôntica e avaliar o efeito do hidróxido de cálcio incorporado sobre o resultado do tratamento. Os cimentos avaliados foram o Procosol, CRCS e Sealapex. 204 dentes foram submetidos ao tratamento endodôntico padrão e foram obturados com guta-percha variando-se o cimento. Os resultados clínicos e radiológicos foram avaliados anualmente, por quatro anos. Os autores concluíram que dentes obturados com resina de salicilato que contêm $\mathrm{Ca}(\mathrm{OH}) 2$ podem garantir uma recuperação mais rápida da periodontite apical ou trauma operatório, mas os resultados após 3 e 4 anos foram estatisticamente insignificantes daqueles obtidos por cimentos a base de ZOE com ou sem Ca $(\mathrm{OH}) 2$. 
ØRSTAVIK et al. (2001) estudaram a alteração dimensional de 11 cimentos endodônticos: cimentos à base de óxido de zinco e eugenol (ProcoSol, Grossman, Pulp canal Sealer e Tubli-seal), resina epóxica (AH 26, AH 26 silverfree e AH Plus $®$ ), hidróxido de Cálcio (Apexit e Sealapex), ionômero de vidro (Ketac-Endo) e um à base de silicone (Roeko-Seal). Utilizaram-se cilindros de $6 \mathrm{~mm}$ de diâmetro por 12 $\mathrm{mm}$ de altura. Logo, que preenchidos os espécimes estes foram mantidos em $100 \%$ de umidade e temperatura de $37^{\circ} \mathrm{C}$. Os cimentos com tempo de presa inferiores ao período de duas horas foram mantidos na estufa úmida por três vezes o tempo de presa, sendo que os cimentos com tempo de presa superiores a este período ficaram no interior da estufa por, no máximo, 26 horas. Os espécimes, três para cada material, foram medidos em ambiente com umidade de $50 \%$ e temperatura de $23^{\circ} \mathrm{C}$ e depois mantidos em frascos com água destilada a $37^{\circ} \mathrm{C}$ e remedidos a cada quatro semanas até a $48^{\mathrm{a}}$ semana. Não se conseguiu realizar o teste com 0 Sealapex devido à inconsistência e instabilidade de se produzir cilindros estáveis de tal dimensionamento do referido cimento. Os resultados demonstraram que, na maioria dos materiais, a maior alteração dimensional se dá nas primeiras quatro semanas. O ProcoSol apresentou uma expansão que excedeu $6 \%$ após um período maior de armazenamento. O AH 26 e AH 26 silverfree, apresentaram uma expansão inicial de 4 a $5 \%$. Já o AH Plus ${ }^{\circledR}$ expandiu inicialmente apenas $0,4 \%$ chegando a $0,9 \%$ nos períodos finais do trabalho. Os autores ainda ressalvam que, a estabilidade dimensional é uma propriedade física necessária para um bom material obturador e quando esta sofre alterações, tipo contração, pode promover lacunas no interior da obturação permitindo que microrganismos se instalem e se reproduzam no interior das mesmas, sendo um fator de insucesso das obturações. 
FAGNANI et al. (2002) descreveram uma metodologia espectrofotométrica para a análise de paraformaldeído presente em amostras de saneantes comerciais e industriais, utilizando-se ácido cromotrópico (ACT), ácido clorídrico concentrado e peróxido de hidrogênio, produzindo um composto púrpura - avermelhado ( $\max =575$ $\mathrm{nm})$. A lei de Beer foi obedecida numa faixa de concentração de 0,8 - 4,8 mg L-1 em formaldeído, apresentando excelente coeficiente de correlação $(r=0,9999)$. Os valores obtidos nas análises concordaram muito favoravelmente com os obtidos pelo procedimento padrão recomendado pelo NIOSH (National Institute for Occupational Safety and Health).

TAl et al. (2002) relataram que frequentemente os cimentos endodônticos são colocados em contato direto com os tecidos vivos, portanto devem ter boa biocompatibilidade. Desta forma, os efeitos patológicos, principalmente genotoxicidade, têm sido estudados sistematicamente sobre células eucarióticas. Os pesquisadores tiveram como objetivo examinar o potencial genotóxico de resinas e cimentos à base de óxido de zinco e eugenol, usando o sistema de teste em mamífero. Nesse estudo foram investigados redução de brometo tetrazólico e teste de precipitação de DNA. A análise de fragmentação de DNA foi realizada com finalidade de investigar o efeito da citotoxicidade e genotoxicidade de quatro diferentes cimentos endodônticos em cultura de células V79. Os resultados mostraram que todos os cimentos endodônticos testados mostraram-se citotóxicos. A citotoxicidade decresceu para os cimentos na ordem do N2, AH 26, AH Plus, Canals. O N2 foi o mais tóxico dos cimentos testados. Os resultados sugerem que os cimentos avaliados nesse estudo mostram diferentes efeitos dependendo dos tipos e dos componentes. Os cimentos endodônticoss, contendo formaldeído e digliether Bis-fenol A, mostram ser não apenas citotóxico, mas genotóxico. Assim o 
sistema de teste em mamífero pode ser usado rotineiramente para avaliação da genotoxicidade de materiais dentários em futuras investigações.

HUANG et al. (2002) desenvolveram um estudo cujo objetivo foi determinar a citotoxicidade de cimentos endodônticos sendo dois resinosos (AH26 e AH Plus), três à base de óxido de zinco e eugenol (Canals, Endomèthasone e N2) e um cimento à base de hidróxido de cálcio (Sealapex) em células do ligamento periodontal humano e em linhagens de células de hamsters (V79). Os resultados indicaram que todos os cimentos se mostraram citotóxicos tanto para as células primárias do ligamento periodontal quanto para as células V79. O cimento à base de hidróxido de cálcio foi o que se apresentou menos tóxico para ambas as culturas. Em ordem decrescente, a resposta citotóxica dos materiais testados foi: N2 > Endomèthasone $>\mathrm{AH} 26>\mathrm{AH}$ Plus $>$ Canals $>$ Sealapex. Baseado nos resultados os autores concluíram que a sensibilidade à toxicidade depende do material testado e da cultura celular usada, e, portanto, consideraram que tanto as células primarias quanto as linhagens celulares são indicadas para os testes de citotoxicidade de cimentos. Os autores ainda ressaltaram o fato de que os cimentos tendem a serem dissolvidos quando expostos ao meio aquoso por tempo prolongado, o que tenderia a aumentar a sua citotoxicidade. Afirmaram também que, a princípio, os cimentos à base de hidróxido de cálcio são os que provocam uma resposta mais favorável dos tecidos perirradiculares.

LOVSCHALL et al. (2002) relataram que os padrões internacionais para os procedimentos pré-clínicos sobre a citotoxicidade de materiais dentários recomendam o uso de células. A proposta do estudo foi de investigar a relativa susceptibilidade de fibroblastos de polpas dentais humanas, células epiteliais bucais humanas e células de câncer cervical da linhagem HeLa expostas a idênticas 
características citotóxicas. O teste químico foi realizado com formaldeído liberado de materiais dentários como resinas compostas, cimentos de ionômero de vidro e cimentos endodônticos. Os dados da citotocixidade, incluindo relação de dose resposta e valores TC (50) foram avaliados em três diferentes análises. Nas condições experimentais em que o trabalho foi desenvolvido, os autores concluem que as células teciduais humanas parecem ser mais sensíveis à toxicidade do formaldeído, do que as células cancerosas da linhagem HeLa.

HUANG et al. (2002) avaliaram a indução de c-fos e c-jun protoncogênicas expressadas pela liberação de formaldeído e resina epóxi em cimentos endododônticos à base de óxido de zinco e eugenol (N2 e Endomèthasone), a base de resina epóxi ( AHPlus) e à base em Hidróxido de Cálcio (Sealapex) em células osteoblásticas (U2 - OS). A citotoxicidade apresentou-se na seguinte ordem decrescente: N2> Endomethàsone> AH Plus> Sealapex. Além disso, N2, Endomèthasone e AHPlus rapidamente induziram c-jun e c-fos em níveis de mRNA nas células. No entanto, o cimento Sealapex não induziu a c-jun e c-fos em níveis de mRNA detectáveis. Tomados em conjunto, a indução persistente de c-jun e protocongenes c-fos pela liberação de formaldeído via ápice para causar alguns efeitos adversos inesperado sem seres humanos. Estes dados devem ser levados em consideração ao escolher um cimento obturador.

LEE at al. (2002) em estudo in vitro, avaliaram a capacidade de adesão entre quatro classes de cimentos endodônticos (à base de óxido de zinco e eugenol ( Kerr); à base de hidróxido de cálcio (Sealapex); resinoso (AH 26) e o cimento KetacEndo à base de ionômero de vidro) à dentina ou guta-percha. Neste teste, cilindros de alumínio de $5 \mathrm{~mm}$ diâmetro foram preenchidos com os respectivos cimentos e assentados em discos de dentina e guta-percha. Após serem mantidos em $100 \%$ 
umidade por $24 \mathrm{~h}$, foram submetidos a forças de tração. Os resultados indicaram a resistência de união dos cimentos à dentina em seguinte ordem crescente: Kerr, Sealapex, Ketac-Endo e AH 26. Os dois últimos foram significativamente diferentes $(p<0,05)$ perante os dois primeiros e entre eles. $\mathrm{AH} 26$ foi significativamente mais adesivo à guta-percha.

CANOVA et al. (2002) avaliaram a biocompatibilidade tecidual dos cimentos Endomèthasone, Sealapex, Sealer Plus e Sealer 26. Para este estudo foram utilizados 48 ratos (Wistar) distribuídos em grupos de seis. Os cimentos foram espatulados e injetados imediatamente no tecido conjuntivo subcutâneo do dorso dos animais. Cada cimento foi avaliado em tempos pós-operatórios de três e seis horas. Com o auxílio de um espectrofotômetro foi possível verificar que no tempo pós-operatório de três horas houve maior quantidade de edema para todos os cimentos. O Endomèthasone e o Sealer Plus apresentaram uma reação inflamatória severa que diminuiu com o tempo. Os cimentos Sealapex e Sealer 26 apresentaram menor índice de exsudato inflamatório sendo considerados os mais biocompativeis.

SCHWARZE et al. (2002) avaliaram a citocompatibilidade dos cimentos N2, Apexit, Roekoseal, AH Plus, Ketac Endo,Endomethasone, com o objetivo de determinar a citotoxicidade de vários tipos de cimentos endodônticos in vitro durante o período de 1 ano. Foram utilizadas raízes de dentes humanas e obturadas com os cimentos acima citados. Além disso, raízes foram obturas com guta-percha na técnica de condensação lateral. Dentes obturados com um ponto de guta-percha foram utilizados como controle. Todas as amostras foram consecutivamente extraídas e armazenadas em água destilada no período de 1 ano. Os grupos foram investigados por citotoxicidade usando fibroblastos 3T3 imortalizado e ligamento periodontal humano primário fibroblastos. Os resultados foram analisados 
estatisticamente com os testes $t$ de Dunnett $(p<0,05)$. Os efeitos citotóxicos foram só causados por N2 em ambas as culturas de células $(p<0,05)$. Além disso, estatística significante de alterações citotóxicas também foram induzidas por 10 semanas dos Endomethasone $(p<0,05)$. Todos os outros cimentos investigados materiais não alteraram significativamente o metabolismo celular.

SCHWARZE et al. (2002) estudaram a citotoxicidade dos cimentos endodônticos N2, Endomèthasone, Apexit, AH Plus e Ketac Endo nas $24 \mathrm{~h}$ imediatamente após a sua espatulação, utilizaram células imortais 3T3 e células primárias do ligamento periodontal humano. Os resultados mostraram que o N2 inibiu completamente o metabolismo celular e que o Endomèthasone também provocou inibição do metabolismo nas primeiras horas, porém, após $24 \mathrm{~h}$ se tornou significativamente menos irritante. O cimento Ketac Endo se mostrou severamente citotóxico, o AH Plus provocou uma importante inibição mitocondrial e o Apexit não apresentou poder citotóxico.

BOJ et al. (2003) pesquisaram com o objetivo de estudar a nefrotoxicidade aguda do formaldeído, causada pelo componente formocresol. A pesquisa foi desenvolvida em ratos e os resultados mostraram que a avaliação histológica das amostras dos rins não apresentou qualquer de lesão, o que também não foi encontrado em outros tecidos. O uso de formaldeído em doses clínicas ou em quantidade equivalente a 100 pulpotomias não produziu danos ao tecido renal e os níveis na urina e no sangue não mostraram alterações significativas após 48 horas do uso do produto.

HAUMAN; LOVE (2003) afirmaram que a biocompatibilidade dos materiais endodônticos deve ser analisada sob vários aspectos como a genotoxicidade, mutagenicidade, carcinogenicidade, citotoxicidade, histocompatibilidade e efeitos 
microbiológicos. Portanto, é impossível caracterizar biologicamente um material utilizando apenas uma metodologia. Estes autores afirmam ainda que os estudos in vitro possibilitam uma melhor padronização, oferecendo resultados mais precisos, reprodutíveis, além de serem de rápida execução.

BERNÁTH; SZABÓ (2003) analisaram o tipo e o grau de reação inflamatória provocada pelos cimentos AH26, Apexit, Endomèthasone e o cimento de Grossman. Neste estudo, vinte e quatro canais radiculares de macacos foram obturados sem extravasamento apical, e oito elementos foram obturados com extravasamento dos cimentos. Os resultados foram obtidos por corte histológico seis meses após o tratamento. No grupo onde não houve extravasamento, nenhuma reação inflamatória foi detectada para os cimentos Apexit e de Grossman, mas os outros cimentos provocaram diferentes graus de reações teciduais inflamatórias. 0 Endomèthasone provocou urna reação moderada em três dos nove casos e o AH26 em dois dos sete casos. No grupo onde houve o extravasamento, todos os cimentos provocaram reações teciduais inflamatórias, porém, o Endomèthasone iniciou um processo granulomatoso de corpo estranho e o $\mathrm{AH} 26$ teve suas partículas envolvidas por macrófagos. Os cimentos Apexit e de Grossman desencadearam apenas um infiltrado de linfócitos e plasmócitos.

MILETIC et al. (2003) estudaram in vitro a ação citotóxica e mutagênica do AH 26 e do AH Plus. O efeito citotóxico em células de 45 hamster V79 foi determinado pela contagem de células viáveis, após a incubação em extratos de $\mathrm{AH}$ 26 e AH Plus. Em um grupo do estudo, os materiais foram manipulados, tomaram presa por uma hora e então imersos em dimetil sulfóxido (DMSO) por 1 h, 24 h e 7 dias. No outro grupo, o AH 26 e o AH Plus foram manipulados e tomaram presa por 1 h, 24 h e 7 dias em solução salina, então foram quebrados e imersos em DMSO 
por 24 h. Foram avaliados os efeitos citotóxicos desses vapores. Nenhum dos materiais induziu um aumento de aberrações cromossômicas ou indução da formação de micronúcleos em qualquer tempo ou concentração. Assim, os autores concluíram que não houve ação mutagênica no $\mathrm{AH} 26$ ou no AH Plus em linfócitos humanos em condições altamente controladas in vitro.

SCHWANDT; GOUND (2003) relataram que o Resorcinol é um cimento endodôntico que contém dois produtos potencialmente tóxicos: o resorcinol (pó) e o formaldeído (líquido). O material poderá conter também óxido de zinco ou sulfato de bário para melhorar a radiopacidade. Quando são adicionados $10 \%$ à mistura, a polimerização acontece, o que pode formar um cimento duro e avermelhado. Os autores ainda relatam que o cimento irá fixar tecido e destruir bactérias através do material. Assim, o material tem sido usado sem instrumentação do canal e sem que a obturação atinja seu comprimento correto. Pouca literatura existe a respeito do índice de sucesso dessa terapêutica.

KAPLAN et al. (2003) realizaram um estudo objetivando determinar a fluidez e as reações do tecido subcutâneo a cinco cimentos endodônticos. Os materiais utilizados foram Procosol, AH 26, Endométhasone, Sealapex e Endion. O estudo foi feito em ratos. Os resultados mostraram que o Endion e o Procosol apresentaram as maiores reações histológicas, as quais eram delimitadas por tecido fibroso. Os cimentos Endomèthasone, $\mathrm{AH} 26$ e Sealapex produziram reações de menor tamanho e com limites mais definidos. Os autores concluíram que não houve relação entre a fluidez e o grau de resposta inflamatória. O Procosol e o Endion produziram a mais severa reação tecidual, embora o Endométhasone, Sealapex e o AH 26 produziram as menores reações. 
YATSUHASHI et al. (2003) relataram dois casos de parestesia do nervo alveolar inferior, onde o agente causador foi o medicamento utilizado no canal radicular. No primeiro caso, a parestesia parece ter sido atribuída à infiltração do hidróxido de cálcio ao canal mandibular, através do canal radicular do segundo molar inferior esquerdo. No segundo caso, a parestesia parece ter sido conseqüência da infiltração do formaldeído através dos canais radiculares do segundo molar inferior direito. A parestesia foi aliviada nos dois casos por irrigação com soro fisiológico em combinação com vitamina B12 e tiosulfato de adenosina.

NAIR (2004) em revisão destaca a química de resinas além da cura-fenólica e discute as diferentes estratégias envolvidas na sua concepção molecular e analisa a síntese, caracterização e cura de notáveis sistemas fenólicos de adição curáveis. Suas propriedades térmicas, físicas e mecânicas são discutidas e as correlações entre estrutura-propriedade examinadas. A revisão inclui discussões sobre as propriedades dos compósitos em casos relevantes. Os sistemas discutidos incluem compostos fenólicos principalmente epóxi fenólicos, fenólicos de éter de acetilenofuncionais e fenólico de triazina. As vantagens e deméritos destes sistemas são discutidos e suas potencialidades de aplicação consideradas.

BOUILLAGUET et al. (2004) avaliaram o selamento por meio da infiltração e a citotoxicidade por meio da atividade da desidrogenase succínica de quatro classes de cimentos endodônticos: PCS (Kerr), RoekoSeal (Roeko), Topseal (Dentsply) e EndoREZ (Ultradent). Para os testes de citotoxicidade, os materiais foram colocados em contato com fibroblastos de rato Balb/ c3T3 (ATCC CCL 163, clone A31; coleção American Type Culture, Rockville, MD, EUA), mantidos em meio DMEM (5\% de soro fetal bovino, $5 \%$ de soro bovino recém-nascidos, $100 \mu \mathrm{g} / \mathrm{mL}^{-1}$ de penicilina, e $100 \mathrm{U} / \mathrm{mL}^{-1}$ de estreptomicina), incubados a $37{ }^{\circ} \mathrm{C}$ e com ar de $5 \%$ de $\mathrm{CO} 2$ para 
permitir a fixação dos fibroblastos. Foram avaliados em três momentos subseqüentes (24 h, $48 \mathrm{~h}$, ou 1 semana). Os resultados mostraram que a citotoxicidade geralmente aumenta com o tempo, e que na maioria dos cimentos os riscos de toxicidade são significantemente maiores quando na condição de imediatamente após espatulados. Os autores concluíram que o RoekoSeal (Roeko), um material a base de silicone, foi de longe o mais promissor dos cimentos testados no presente estudo apresentando baixa citotoxicidade e boa capacidade de selamento do canal radicular e afirmaram que apesar disso não foi ideal e que mais estudos são necessários no desenvolvimento de melhores materiais.

HAUPTMANN et al. (2004) estudaram a possível relação entre a exposição de trabalhadores ao formaldeído e câncer linfohematopoético. O contingente pesquisado consistiu de 25.619 trabalhadores (de 865 a 708 pessoas por ano) empregados em um parque industrial dos Estados Unidos, desde Janeiro de 1966 a dezembro de 1994. Os autores avaliaram exposição ao formaldeído (exposição máxima, exposição média, exposição cumulativa e duração da exposição) e mortalidade provocada pelo linfohematopoiético maligno, usando as taxas de mortalidade padrão e relativa. A análise estatística mostrou que entre os profissionais observados houve 2099 mortes por câncer, sendo 178 mortes de malignicências hematopoiéticas. O risco relativo de câncer de nasofaringe (9 mortes) aumentou com a exposição média e cumulativa, com aumentos dos picos de exposição e duração da exposição ao formaldeído. Não houve uma associação clara da exposição do formaldeído com câncer de pulmão (744 mortes), pâncreas (93 mortes), cérebro (62 mortes) ou próstata (145 mortes). Houve também 69 mortes por leucemia. Os riscos relativos para leucemia não foram associados com exposição cumulativa, mas ligeiramente associados com a duração da exposição. Os riscos 
relativos para a doença de Hodgkin também aumentou com a maior exposição ao formaldeído. Assim, os autores concluem que a exposição ao formaldeído pode causar leucemia, particularmente a leucemia mielóide em humanos. Os autores sugerem cautela na obtenção de conclusões definitivas.

GOMES et al. (2004) em avaliação, in vitro, da atividade antimicrobiana de cinco cimentos endodônticos, afirmaram que o poder antimicrobiano é maior em um cimento que contenha na sua formulação substâncias tais como: paraformaldeído, eugenol e timol. Entretanto, ocorre também um aumento de sua toxicidade provocando danos aos tecidos periapicais, o que não compensa os benefícios da propriedade antibacteriana do material. De um modo geral, as atividades antimicrobianas do Endomèthasone e do Endomèthasone $\mathrm{N}$ foram semelhantes. $\mathrm{E}$ os autores assim sugeriram que a presença do paraformaldeído não aumentou o poder antimicrobiano do Eadornèthasone sobre os microrganismos testados. Os autores ainda enfatizaram o fato de que a ausência do paraformaldeído na composição do Endomèthasone $\mathrm{N}$ segue a tendência mundial de se remover as substâncias tóxicas da composição dos biomateriais.

HUANG et al. (2005) avaliaram os efeitos antioxidantes tais como: catalase e $\mathrm{N}$-acetil-L-cisteína (NAC) e a citotoxicidade dos cimentos N2 e Endomèthasone em uma linhagem de células U2OS de osteoblastos humanos. Os dados mostraram que a ativação da COX-2 pode ser uma das patogenias provocadas pelos cimentos à base de óxido de zinco e eugenol contendo formaldeído resultando em uma inflamação periapical. Os autores ainda relatam que se acredita que a cicloxigenase2 seja a enzima responsável pela síntese de prostaglandina nos locais de inflamação. No entanto, pouco se sabe do quanto uma interação química é capaz de 
modular a COX-2 e da citotoxicidade induzida por cimentos endodônticos à base de óxido de zinco e eugenol contendo formaldeído.

FRANKS (2005) estudou a absorção e o metabolismo de vapor de formaldeído em seres humanos. Por meio de um modelo matemático pré-formulado pode-se calcular a concentração e a atividade metabólica de formaldeído presente na mucosa, no muco, no epitélio e no sangue após a inalação do gás de formaldeído. O autor concluiu que é altamente improvável que o formaldeído causa toxicidade em outros locais a não ser o de contato inicial, no caso o trato respiratório.

WHITWORTH (2005) relatou uma visão geral dos princípios e práticas correntes no preenchimento de canais radiculares procurando desvendar os limites e muitas vezes contraditórios da relevância da pesquisa na prática e desempenho clínico. O autor relatou que o sucesso é mais provável em dentes que foram densamente obturados a $2 \mathrm{~mm}$ do ápice, porém não é claro se a obturação do canal radicular em si é um fator determinante no resultado e se diferentes materiais e métodos empregados, na obtenção de uma obturação "satisfatória", pode ter impacto neste. Sua conclusão foi que a ciência clínica da obturação do canal é fraca e ponderada para estudos de laboratório, muitas vezes de duvidosa relevância clínica e com pouca padronização de método. O autor encerrou afirmando que existe uma necessidade de traduzir a prática diária em dados de pesquisa para assim fornecer forte evidência e apoiar o cuidado aos pacientes.

ØRSTAVIK (2005) afirmou que o uso de pastas foram introduzidas no final do século 19, com anti-sépticos fortes (fenol, cânfora, fenol creosoto, e paraformaldeído) adicionado, por exemplo, aos cimentos de óxido de zinco-eugenol. Pouco depois, o hidróxido de cálcio também foi adicionado ao arsenal endodôntico. 
Na Europa o paraformaldeído foi adicionado com finalidade antibacteriana, na pasta N2 controversa e na Endomethàsone. Os cimentos a base de óxido de zincoeugenol têm alguma atividade antibacteriana própria, mas também apresentam alguma toxicidade, quando colocados diretamente sobre os tecidos vitais. De longe o mais bem sucedido dos cimentos à base de resina foi a série $\mathrm{AH}$. O protótipo desenvolvido há mais de 50 anos atrás por Andre Schroeder na Suíça é uma resina bis-fenol usando a metenamina para polimerização. Como a metenamina (também conhecido como urotropin) emite alguns formaldeídos durante a reação, alternativas foram pesquisadas e encontradas por meio de uma mistura de aminas, que afetam a polimerização sem a formação de formaldeído. O AHPlus é o resultado dessa evolução. Outra formulação do cimento amplamente utilizado em muitas partes do mundo é o tipo resorcina-formaldeído, uma variante do fenol-formaldeído. Este cimento é fortemente antibacteriano, mas retrai e deixa uma tonalidade avermelhada na estrutura dentária (daí o apelido "Vermelho russo") e tem seu uso defendido sem a necessidade de cones de guta-percha, e, como ele se torna muito duro e de massa insolúvel, o retratamento de dentes obturados com este material pode se tornar uma experiência muito frustrante.

PINEDA et al. (2005) compararam os níveis de infiltração apical de corante azul de metileno em pré-molares superiores, birradiculares, com raízes divergentes e ápice completamente fechado, quando uma das raízes foi instrumentada com a técnica escalonada e a outra raiz com o Sistema Profile. Os dentes foram instrumentados com limas K-Flexofile e limas do sistema Profile, e obturados com cones de guta percha e cimento Endofill, usando-se a técnica de condensação lateral. A infiltração apical foi avaliada por medida linear, em lupa estereoscópica, por dois examinadores. Os resultados mostraram que, independentemente da 
técnica de instrumentação utilizada, aconteceu infiltração. Observou-se que os maiores níveis de infiltração aconteceram nas amostras que foram instrumentadas com a técnica rotatória. Nesses dentes, a matriz apical não foi conformada. Estatisticamente, os valores de infiltração entre os grupos experimentais não foram significantes $(p=0,0753)$. Segundo os autores, durante o preparo do canal, faz-se a sua modelagem para posterior obturação, que deve ser o mais hermética possível para propiciar a marcha da cicatrização, promovendo o sucesso da terapia. Para que isso seja possível, a escolha do cone principal e a utilização de um cimento obturador são pontos fundamentais nessa etapa do tratamento. A não-observância desses princípios pode levar ao fracasso do tratamento endodôntico, devido à infiltração através do forame apical.

WU et al. (2006) avaliaram questões relacionadas ao tratamento endodôntico e o combate à infecção dos canais radiculares, bem como alguns aspectos relacionados à infecção residual no tratamento, em artigo de revisão de literatura. Para os autores, o desenvolvimento de tratamentos que possam efetivamente eliminar a infecção radicular é uma prioridade na pesquisa endodôntica clínica. Doenças que se seguem ao tratamento endodôntico realizado estão frequentemente associadas com a realização de procedimentos operatórios deficientes, que não removem a infecção intracanal. Essa situação, esclarecem os autores, pode ser corrigida pela via não cirúrgica. Entretanto, infecção remanescente, em áreas inacessíveis, extrarradiculares, aqui incluída a dentina extruída além do forame apical, com bactéria presente nos túbulos dentinários, cistos radiculares verdadeiros, e reações de corpo estranho, requerem intervenção cirúrgica. Todo o espaço preparado e limpo do canal radicular deve ser preenchido pela obturação, com o 
objetivo de evitar patologias posteriores. Não se pode deixar espaços que permitam a instalação e proliferação de microrganismos, esclarecem os pesquisadores.

ORSIĖRE et al. (2006) estudaram o risco de genotoxicidade de trabalhadores de laboratórios de anatomia e patologia expostos ao formaldeído usando análises de dano de linfócitos periféricos ao DNA e amostras de ar. Os níveis de exposição ao formaldeído foram determinados monitorando a respiração passiva de 59 trabalhadores de 15 minutos a 8 horas e para avaliar os danos em DNA utilizaram ensaio de quimioluminescência em 57 trabalhadores depois de 1 dia de exposição. As concentrações médias de formaldeído encontradas $2.0(<0.1-20.4$ ppm) e 0.1 ppm 9<0.1-0.7 ppm) para as exposições de 15 minutos e 8 horas respectivamente e não observaram aumento no dano ao DNA detectado em linfócitos após um dia de trabalho. Os autores realçam que os patologistas e anatomistas necessitam do desenvolvimento de programas seguros de trabalho.

KOSEOGLU et al. (2006) relataram clinicamente de um caso de parestesia que ocorreu devido à extrusão do cimento endodôntico Endomèthasone. Segundo os autores o material é neurotóxico e contém formaldeído e eugenol. E ainda relatam que de acordo com a literatura neste tipo de caso é feita a imediata descompressão cirúrgica do material extruído até o canal mandibular. A cirurgia de remoção do material foi feita três semanas após o tratamento endodôntico. A parestesia cessou apenas quatro meses após a cirurgia, o que sugere segundo os autores, que os efeitos neurotóxicos do Endomèthasone são reversíveis com sua remoção, três semanas após a sobre obturação ter ocorrido.

BOUILLAGUET et al. (2006) realizaram um estudo que teve por objetivo avaliar a citotoxicidade dos cimentes AH Plus, Epiphany e Gutta flow. Para tal foi empregado o método MTT onde as amostras foram colocadas após a sua 
espatulação diretamente sobre a cultura de células. Os resultados foram observados após 24 e 72 h e mostraram que todas as amostras eram citotóxicas e que a toxicidade aumentava com o tempo. O cimento Gutta flow se apresentou menos tóxico do que o $\mathrm{AH}$ Plus e Epiphany. O autor enfatiza a necessidade de se desenvolverem cimentos melhores que combinem excelentes propriedades de selamento e adesividade das resinas com propriedades biológicas aceitáveis para o emprego na prática endodôntica.

SCHWARTZ (2006) em uma revista de literatura mostrou que materiais obturadores adesivos foram desenvolvidos em um esforço para prover um selamentto coronário e apical mais efetivos e que estes materiais foram desenvolvidos para a dentística tendo sido aplicados nos materiais obturadores canais e mostrou os obstáculos do efeito adesivo no sistema de canais radiculares, os progressos alcançados e as estratégias possíveis para melhora futura destes materiais.

CORTÉS et al. (2007) relataram que vários estudos têm questionado os efeitos tóxicos do formocresol, incluindo a distribuição sistêmica. Foi realizado estudo para que fosse determinada a possibilidade de eventuais riscos de ocorrência às lesões hepáticas, após o uso de injeção intravenosa de formaldeído em doses usadas em múltiplas pulpotomias em ratos. Avaliaram alterações histológicas e bioquímicas. Os resultados mostraram que doses muito altas de formaldeído injetadas em ratos, doses maiores do que aquelas usadas para múltiplos tratamentos pulpares em sessão única em Odontopediatria, não mostraram sinais de toxicidade em fígado de ratos.

MAZINIS et al. (2007) com o intuito de encontrar uma correlação entre as alterações na dureza da superfície dos cimentos e transformações químicas que 
ocorrem por toda a massa do material, durante o tempo de endurecimento, os autores apresentaram um estudo onde monitoravam a reação de presa de quatro cimentos endodônticos pelo método de espectrometria infravermelha de Fourier. Os cimentos estudados foram o Roth 811, Endion e Sealapex, que tomam presa por uma reação ácido-base e o $\mathrm{AH} 26$ silverfree que produz uma reação de polimerização catiônica. Cinco espécimes de cada cimento foram colocados em anéis de $10 \mathrm{~mm}$ de diâmetro por $1 \mathrm{~mm}$ de altura a $37^{\circ} \mathrm{C}$ e umidade relativa de 100 \%. O tempo de presa foi determinado de acordo com a International Standard 6876 (ISO 6876). Foram preparados três espécimes para cada material sendo realizadas quatro leituras como se segue: A - imediatamente após a espatulação; B aproximadamente após metade do tempo de presa determinado pelo teste ISO; C no tempo de presa e D - no período de três vezes o tempo de presa. Os resultados do tempo de presa de acordo com a ISSO mostraram um valor médio de 5.754 minutos para o Roth 811 e de 27 minutos para o Endion. Os espectros dos cimentos demonstraram que todo o eugenol do Roth 811 é consumido no tempo de presa. Já o Endion apresentou $48 \%$ dos seus componentes sem reagirem no tempo de presa, e a conversão dos grupos carboxila continuou por um período bem maior que esse tempo. Observaram que o Sealapex apresenta uma limitada interação entre os componentes de suas duas pastas havendo pouca matriz do cimento formada no tempo de presa. Com relação ao $\mathrm{AH} 26$, verificaram que, apesar de ser um cimento que não contém formaldeído, contém a hexametilenotretamina, a qual é hidrolisada em amônia e formaldeído alcançando altos níveis de concentração desses produtos dois dias após a mistura.

HO et al. (2007) estudaram a citotoxicidade do formaldeído dos cimentos obturadores de canais em células osteoblásticas humanas relacionada aos níveis de 
glutationa intracelular. Relataram que estes materiais extruídos na região periapical poderiam participar no desenvolvimento de inflamação periapical e na persistência de lesões pré existentes. Realizaram ensaios de citotoxicidade e proliferação celular para elucidar os efeitos adversos do formaldeído em células osteoblástica humanas in vitro. Concluíram os autores que o formaldeído teria potencial para citotoxicidade periapical significante.

GATEWOOD (2007) relatou que os princípios biológicos da terapia endodôntica são muito bem estabelecidos. A limpeza completa do sistema de canais para torná-lo o mais livre possível de bactérias e seus produtos, seguido de obturação completa do sistema de canais, evitando infiltrações apical e/ou coronal, criará um ambiente propício à cura perirradicular.

JAINAEN et al. (2007) avaliaram a resistência dos cimentos AH Plus, EndoREZ e do sistema Resilon (RealSeal), por meio do teste de push-out, e o aspecto das falhas observas em MEV. Trinta pré-molares com dois canais separados foram submetidos à remoção de suas coroas na junção cemento esmalte, ao preparo endodôntico com instrumentos Profile.04 e irrigação final com EDTA a 15\%. Divididos em três grupos para obturação com três diferentes cimentos: AH Plus Jet, EndoREZ e RealSeal. Na obturação do canal vestibular de cada espécime foi utilizado um cone principal, guta percha para os cimentos AH Plus e EndoREZ, ou Resilon para cimento RealSeal. Na obturação do canal palatino de cada espécime foi utilizado apenas cimento. Os espécimes foram seccionados em $1 \mathrm{~mm}$ de espessura e submetidos ao teste de push-out. Os resultados mostraram maiores valores com diferença estatisticamente significante para o AH Plus sem guta percha e com guta percha (2,0 e 6,6 MPa), seguido do sistema Resilon (0,4 e 3,4 MPa) e EndoREZ (0,4 e 0,9 MPa). Houve penetração do cimento nos túbulos dentinários em 
todos os cimentos, a uma profundidade de pelo menos $200 \mu \mathrm{m}$. Os autores ressaltaram a importância das qualidades da obturação dos canais radiculares, afirmando que ideal é aquela obturação na qual o espaço do canal radicular seja preenchido sem falhas ou espaços. Cimento e cone de guta percha ou resina deveriam formar uma massa uniforme, aderida quimicamente, e também aderida à dentina para evitar a infiltração bacteriana.

KOPPER et al. (2007) avaliaram o diâmetro da ponta de cones de guta percha principais, de $1^{\mathrm{a}}$ e $2^{\mathrm{a}}$ séries, de várias marcas, para avaliar se estavam de acordo com a especificação da American National Standards Institute/American Dental Association (ANSI/ADA) n. 78. A mensuração dos cones revelou que apenas os cones de número 15 não diferiram entre as marcas estudadas, sendo que o diâmetro da ponta dos cones de guta percha números 35 e 55, da Tanari, 15, 45 e 70, da Endopoits, e 20, 25, 30, 35, 40, 45, 50, 55, 60, 70, 80, da Dentsply-Maillefer, apresentou diferenças estatisticamente significativas $(p \leq 0,05)$ quando comparado ao valor estabelecido pela especificação da ANSI/ADA n. 78. Concluíram que os cones de guta percha números 35 e 55 da Tanari, números 15, 45 e 70 da Endopoints e todos, com exceção dos de número 15, da Dentsply-Maillefer, não estão de acordo com a especificação da ANSI/ADA n. 78. Segundo os autores, os cones de guta percha principais, de acordo com a especificação citada, devem apresentar calibre e conicidade compatíveis com as limas endodônticas convencionais, e suas seleções constituem etapa importante no procedimento de obturação, já que deverão se adaptar perfeitamente na porção apical do canal radicular, proporcionando vedação apical que impeça a entrada de fluidos teciduais periapicais, microrganismos e seus produtos no canal radicular já obturado. Caso a padronização dos cones principais 
esteja adequada, o cone de calibre compatível com o do último instrumento empregado na confecção do batente apical terá a adaptação desejada.

HUANG et al. (2008) realizaram um estudo histológico para demonstrar que os cimentos obturadores endodônticos podem induzir inflamações de média a severas afirmando que a proteólise da matriz extracelular por metaloproteinases (MMPs) e ativadores plaminogênicos (PAs) parecem ser a chave iniciadora para a progressão do processo inflamatório. Foram avaliados o cimento à base de resina epóxica (AH26), um cimento à base de óxido de zinco e eugenol (Canals) e uma pasta seladora (N2). Os resultados demonstraram que todos os produtos testados apresentaram citotoxicidade de uma maneira concentração-dependente ás células U2OS.

KOAGEL et al. (2008) realizaram estudo in vitro para avaliar a microinfiltração marginal de Tempit UltraF, Tempit, IRM, Cavit em 55 dentes unirradiculares humanos, instrumentados pela técnica crowndown até a lima 45. A camada de smear foi removida com banho de 1 minuto cometilenodiaminotetracético $17 \%$ seguida por um banho de 10 minutos com $\mathrm{NaOCl} 5,25 \%$ e secos com cones de papel. As raízes foram obturadas com guta-percha cimento AHPlus, utilizando técnica de onda contínua decondensação. Os dentes foram distribuídos aleatoriamente em 4 grupos de 10 dentes. As aberturas dos dentes nos grupos experimentais foram preenchidos com $4 \mathrm{~mm}$ de Cavit, IRM, Tempit, ou Tempit-UltraF. Todos os dentes foram armazenadas em $100 \%$ de umidade a $37^{\circ} \mathrm{C}$ durante 10 dias.Após termociclagem por 500 ciclos $\left(5^{\circ} \mathrm{C}-55^{\circ} \mathrm{C}\right)$, a microinfiltração foi medida usando o modelo de transporte de fluidos a 10 psi.Todos os materiais testadas apresentaram micro infiltração. Os testes de Kruska Wallis e Mann-Whitney indicaram microinfiltração significativamente menor $(P<0,05)$ com Tempit UltraF em 
comparação ao Cavit e ao IRM. Houve diferenças estatisticamente significativas entre Tempit Ultra-F e Tempit ou mentre Cavit, IRM, e Tempit.

JACK; GOODELL (2008) estudaram in vitro, a microinfiltração coronal entre o Resilon e a Guta Percha com tampão de ionômero de vidro. Os autores utilizaram 34 dentes, os quais tiveram suas coroas removidas, comprimento padronizado de 16 $\mathrm{mm}$, e instrumentados até a lima 40 0.6. Removido o grupo controle, os corpos de prova foras distribuídos aleatoriamente em 2 grupos com 15 corpos de prova cada, sendo um grupo obturado com guta percha com tampão de $2 \mathrm{~mm}$ e outro com Resilon. Os dentes foram avaliados quanto à microinfiltração. Um teste t de Student encontrou significativamente menos infiltração para o lonômero de vidro/ gutapercha do que o grupo só com o Resilon $(p=0,008)$.

SOUZA et al. (2009) estudaram a influência da técnica de obturação e a área do canal sobre a porcentagem de guta percha (PGP) em obturações feitas pela técnica da condensação lateral. Valeram-se de 60 caninos extraídos, que tiveram seus canais obturados até o mesmo diâmetro. Foram divididos em 3 grupos e obturados com condensação lateral de cones de guta percha e cimento AHPlus, usando diferentes técnicas. As raízes foram seccionadas a 3 e $6 \mathrm{~mm}$ do ápice e foi realizada $\mu \mathrm{CT}$. As áreas dos canais e da guta percha foram medidas e a PGP calculada. A área do canal influenciou a PGP, que foi menor no nível de $3 \mathrm{~mm}$. A técnica do espaçador conseguiu a mais alta PGP. Os autores concluíram que variações na técnica de obturação e a área do canal influenciaram a PGP de obturações realizadas pela técnica da condensação lateral. A guta percha é rotineiramente utilizada de forma associada com um cimento para a obturação dos canais radiculares, esclareceram os autores. Ela é dimensionalmente estável, ao passo que a maioria dos cimentos apresenta solubilidade, com probabilidade de 
infiltração ao longo do tempo. Em termos gerais, as técnicas que utilizam a compressão da guta percha são as preferidas com a finalidade de maximizar o volume desse material na obturação, o que resulta em camada mais fina de cimento obturador nas paredes do canal. Assim, a porcentagem de área do canal preenchida pela guta percha é utilizada como uma medida da qualidade da obturação.

BERGER (2009) avaliou a composição química da parte inorgânica e a presença de formaldeído de sete cimentos endodônticos, sendo quatro a base de óxido de zinco e eugenol (Targer Canal Sealer - Konne; Endo Fill - Dentsply; Endométhasone N - Septodont e; Pulp Canal Sealer EWT - Kerr); dois a base de agregado trióxido mineral (MTA) (Endo CPM Sealer - EGEO Dental e Obtura Ângelus) e um a base de resina/hidróxido de cálcio (Sealer 26, Dentsply). Para isso foram utilizados dois métodos: a difratometria de raios $X$, para a análise da parte inorgânica da composição química dos cimentos, onde estes logo que manipulados, foram inseridos em um recipiente de alumínio medindo $5 \mathrm{~cm}$ de diâmetro e $0,5 \mathrm{~cm}$ de altura com uma perfuração de $2 \mathrm{~cm}$ de diâmetro e profundidade de $2 \mathrm{~mm}$ sendo submetidos ao teste logo após presa. Para a verificação da liberação de formaldeído, os cimentos após espatulação, também em proporções de acordo com os fabricantes foram moldados em blisters de cápsulas farmacêuticas e deixados em repouso por $24 \mathrm{~h}$, em seguida foram levados a extração com $2 \mathrm{~mL}$ de metanol em ultra-som durante 15 minutos. Após a extração, as amostras foram filtradas e a solução obtida foi analisado via cromatografia gasosa. Os resultados demonstraram que todos os cimentos Target Canal Sealer e Endo fill, apresentam em sua composição sulfato de bário e carbonato de bismuto, o Endométhasone $\mathrm{N}$ apresentou apenas sulfato de bário e o Pulp Canal Sealer, prata metálica. Já o cimento a base de resina/hidróxido de cálcio, Sealer 26, apresentou óxido de 
bismuto, hidróxido de cálcio, dióxido de titânio e óxido de ferro. Os dois cimentos a base de MTA testados, Endo CPM Sealer e Obtura, apresentaram basicamente, silicato de cálcio. Componentes tais como sulfato de bário e carbonato de cálcio foram encontrados no Endo CPM Sealer e hidróxido de cálcio e silicato de magnésio foram encontrados no Obtura. Em relação à presença de formaldeído, todos os materiais testados apresentaram a substância após a manipulação. Com base nestes dados, foi concluído que ocorreram discrepâncias entre o que foi identificado em relação ao que foi anunciado pelo fabricante.

BRKIĆ et al., (2009) relatou 2 casos clinicos de complicações iatrogênicas de dentes tratados endodonticamente com tratamento por meio de abordagem ciruúrgica. No primeiro caso, material endodôntico extravazado se encontravana região periapical do dente inferior segundo pré-molar causando parestesia do nervo mental; no segundo caso, material extravasado perfurou o osso cortical da maxila, rompeu o periósteo atingindo fibras musculares. O autor afirmou que todos os cimentos endodônticos são neurotóxicos em algum grau e a neurotoxicidade química é o resultado dos componentes dos materiais extravasados. Mesmo os componentes que se acreditam ser benignos, tais como óxido de zinco, eugenol e hidróxido cálcio (devido ao pH elevado), têm se mostrado neurotóxicos in vitro e são certamente neurotóxicos in vivo e que eugenol e paraformaldeído são os principais materiais causadores de reações neurotóxicas.

ZHANG et al. (2010) tiveram como objetivo determinar se a exposição ao formaldeído interrompe a função hematopoiética e produz alterações cromossômicas leucêmicas em humanos. Para isso, os pesquisadores examinaram a capacidade do formaldeído em interromper a função hematopoiética em 94 trabalhadores na China, sendo que 43 foram expostos ao formaldeído e 51 
controlados pareados por freqüência), mensuraram por hemogramas completos e periféricos da haste progenitora da formação de colônias de células. Além disso, cultivaram células progenitoras mielóides dos trabalhadores para quantificar o nível de alterações cromossômicas específicas da leucemia, incluindo monossomia 7 e trissomia 8. Entre os trabalhadores expostos, a contagem de células do sangue periférico foram significativamente reduzidos de uma forma consistente com tóxicos efeitos sobre a medula óssea e as alterações específicas do cromossomo leucêmico foram significativamente elevados em células progenitoras mielóides do sangue. Estes achados sugeriram que a exposição formaldeído pode ter um impacto adverso sobre o sistema hematopoiético e que a indução de leucemia pelo formaldeído é biologicamente plausível, o que aumenta as preocupações sobre o seu potencial leucêmico a partir de exposições ocupacionais e ambientais.

AL-HIYASAT et al. (2010) avaliaram o efeito citotóxico de 4 cimentos endodonticos; AHPlus, EndoREZ, Epiphany e MetaSeal. Utilizaram na avaliação da citotoxicidade Fibroblastos Balb C 3T3 que foram rotineiramente mantidas em meio DMEM (5 \% de soro fetal bovino, $5 \%$ de soro bovino recém-nascidos, $100 \mu \mathrm{g} / \mathrm{mL}-1$ de penicilina, e $100 \mathrm{U} / \mathrm{mL}-1$ de estreptomicina). Para o teste de citotoxicidade, $10 \mu \mathrm{L}$ de eluir tanto o puro ou o diluído ( 1 em $10 \mathrm{v} / \mathrm{v}$ ) do cimento endodôntico foi incubado com $90 \mu \mathrm{L}$ de suspensão de células $(5 \times 105$ celulas/mL-1) em uma placa de cultura. As células foram incubadas por 48 horas a $37{ }^{\circ} \mathrm{C}$ e $5 \%$ CO2. Os controles consistiram de células incubadas com um volume equivalente de solução estéril de fosfato tamponado. Os autores concluíram que todos os cimentos são citotóxicos em diferentes graus. Em ordem crescente de toxicidade: AHPlus, EndoRez, Epiphany e Metaseal. Os autores relataram que um dos fatores que contribui para a 
citotoxicidade de AHPlus é a liberação continua de pequenas quantidades de formaldeído presente no cimento.

KIM et al. (2010) realizaram uma análise crítica sobre o Metacrilato, em cimentos obturadores resinosos, com objetivo de esclarecer o comportamento destes materiais, bem como avaliar sua aplicação clinica. Os autores ressaltaram a introdução destes cimentos a partir da década de 70, entretanto o entusiasmo inicial foi decrescendo a partir dos pobres resultados físico-químicos e biológicos dos cimentos. Com os avanços tecnológicos, no século XXI, o cimento resinoso foi reintroduzido na Odontologia. Três gerações diferentes destes cimentos foram disponibilizadas comercialmente, entretanto, alguns estudos in vitro, com relação à capacidade de vedação, potencial e facilidade de remoção da própria obturação foram mais satisfatórios que os próprios cimentos endodônticos convencionais. Concluíram os autores, com base nos estudos in vivo e in vitro disponibilizados até aquele momento, que não havia nenhuma evidência clara com relação o benefício do uso do cimento resinoso a base de metacrilato.

ARI et al. (2010) avaliaram a capacidade de selamento apical do Hybrid Root SEAL (MetaSEAL), conjuntamente com diferentes técnicas de obturação dos canais radiculares. Para isso, utilizaram 68 molares inferiores humanos extraídos, com raiz única e reta, ápices fechados, que foram preparados pela técnica de instrumentação step-back, e divididos em 4 grupos experimentais $(n=15) .8$ dentes foram preparados como controle (3 positivos, 3 negativos e 2 mais para calcular $100 \%$ de infiltração). Os grupos experimentais foram obturados pela técnica de condensação lateral fria, condensação vertical, Thermafil e Ultrafil. A movimentação de fluidos ao longo dos canais obturados foi medida. Os resultados mostraram que a técnica de condensação lateral fria e da condensação vertical apresentaram significantemente 
menos movimento de fluido do que os grupos do Ultrafil e Thermafil, sendo que este apresentou os maiores valores de movimento de fluido. Os autores destacaram que o objetivo final dos procedimentos endodônticos é a obturação tridimensional total do sistema de canais radiculares. Para isso, utiliza-se, rotineiramente, a guta percha associada a cimentos obturadores, combinadas a várias técnicas. A guta percha não adere às paredes dos canais, e várias tentativas são feitas para solucionar a questão da obturação. A técnica de obturação da condensação lateral fria é a mais difundida para esse propósito. A condensação vertical é tida como a que proporciona maior densidade da guta percha na porção apical da obturação, e oblitera canais laterais e foraminas, de forma consistente. Há, ainda, a tentativa de fusão da guta percha, como no caso do Thermafil e do Ultrafil, com o objetivo de se obter uma massa homogênea do material e fazê-lo penetrar nos túbulos dentinários. A guta percha, esclarecem os autores, no interior dos canais radiculares, não é dimensionalmente estável, o que faz com que seja utilizada associada a um cimento obturador. Um selamento pobre pode resultar em falhas na região apical, que se tornam sítio de alojamento de fluidos tissulares. Assim, a vedação apical é desejável para prevenir a presença de bactérias remanescentes e suas endotoxinas, bem como a de fluidos tissulares originas a partir do ápice radicular. A obturação tridimensional dos canais radiculares, bem compactada, previne a percolação e a microinfiltração de exsudatos periapicais para o interior do espaço dos canais, previne a reinfecção e cria ambiente biológico favorável para a cura, esclarecem os pesquisadores.

KARAPINAR-KAZANDAG et al. (2011) avaliaram a citotoxidade de 5 cimentos endodônticos em linhagem em fibroblastos L929 de ratos e células humanas da polpa dental. Corpos de prova cilíndricos de AH Plus (Dentsply De Trey GmbH, 
Konstanz, Alemanha), Roeko-Seal (Coltène Whaledent, Langenau, Alemanha), EndoREZ (Ultradent Products Inc., South Jordan, UT, EUA), Epiphany (Tecnologias Pentron Clínica, LLCC, Wallingford, CT, EUA) e Activ GP (Brasseller Inc., EUA, Savannah, GA, EUA) foram mantidos a $37^{\circ} \mathrm{C}$ em um atmosfera úmida anaerobiose de $5 \%$ com três vezes o tempo de endurecimento determinado pelo fabricante. As amostras, foram avaliadas após crescimento celular em 1, 4 e 7 dias. Não diluídos, $50 \%$ e $25 \%$ diluídas foram incubadas em cultura células para 24 e 72 h. A Citotoxicidade foi avaliada usando bioensaio colorimétrico. O teste de Kruskal-Wallis e teste de Dunn de comparação múltipla foram usados para os cimentos diluídos/não-diluídos em termos de viabilidade celular (\% do controle). Teste de Friedman e teste de Dunn foram realizados para comparar períodos de extração. O Teste de Wilcoxon foi utilizado na comparação entre os períodos de 24 e $72 \mathrm{~h}$. Os autores observaram que o Active GP não diluído em um dia foi significativamente mais citotóxico do que todos os outros cimentos $(P<0,0001)$. Não diluídos em 4 e 7 dias de Epifany e Activ GP foram significativamente mais citotóxico que os outros três aferidos $(P<0,0001)$. Activ GP e a Epifany eram geralmente menos tóxicos do que o não diluído. A citotoxicidade do Epifany aumentou significativamente à medida que o período de maior extração $(P<0,0001)$. $O$ cimento Epifany tornou-se mais tóxico com o tempo de exposição para as células. Citotoxicidade nenhuma ou mínima foi observado com os cimentos RoekoSeal, Plus e AH EndoREZ. Concluíram os autores, que os cimentos obturadores apresentaram graus diferentes de citotoxicidade dependente de sua composição química.

GIOVANINI et al. (2011) avaliaram em ratos, por meio da histologia e da imunohistoquímica, a relação entre as reações inflamatórias induzidas pelos cimentos endodônticos; Endofill, AH Plus, Epiphany e Acroseal; a ocorrência de 
fibrose e do número de miofibroblastos com positividade para o músculo liso a-actina no período pós-operatório de 07, 21 e 45 dias. Tubos de polietileno foram preenchidos com os cimentos (I: Endofill; II: AH Plus; III: Acroseal; IV: Epiphany) e inseridos em 4 regiões do dorso de 24 ratos Wistar, enquanto 2 tubos vazios (V controle) foram inseridos em 6 ratos. Após 7, 21 e 45 dias, oito animais foram sacrificados obtendo 6 indivíduos por grupo e 2 para o grupo controle. Os fragmentos foram submetidos ao processamento histológico e à análise imunohistoquímica para a proteína anti-a-SMA. Todos os grupos, exceto o controle, demonstraram notável reação inflamatória no $7^{\circ}$ dia pós-operatório, que também coincidiu com uma grande quantidade de miofibroblastos. No $21^{\circ}$ e $45^{\circ}$ dia pósoperatório, a reação inflamatória induzida pelo Endofill, AH Plus e Acroseal diminuiu significativamente, o que coincidiu com reduzida presença de miofibroblastos e deposição de colágeno normal. Em contraste, no grupo Epiphany, infiltrado inflamatório significativo esteve presente em todos os períodos analisados. Os autores concluíram que a persistência do infiltrado inflamatório induzido por cimento endodôntico pode também provocar uma fibrose associada com a presença de miofibroblastos.

LOUSHINE et al. (2011) estudaram o tempo de endurecimento e a microdureza de um cimento obturador à base de fosfato de cálcio e silicato (BC Sealer) em presença de diferenças misturas e compararam a citotoxicidade com um cimento á base de resina epóxica (AHPlus). Observaram que o BC Sealer® necessita de pelo menos 168 horas para endurecimento e que sua microdureza diminui significativamente na presença de água e promove citotoxicidade severa até um período de 24 horas, já o AHPlus tem diminuição de sua toxicidade e se torna não citotóxico enquanto o BC Sealer permanece tóxico até um período avaliado de 6 
semanas. Os autores concluíram que mais estudos deveriam ser feitos para correlacionar o tempo de endurecimento do BC Sealer e seu decréscimo de citotoxicidade.

CHANDRASEKHAR et al. (2011) avaliaram a expansão tridimensional da guta-percha em diversas proporções pó/líquido do cimento EWT (a base de ZOE) por meio da tomografia computadorizada helicoidal. Os Dentes foram seccionados na junção amelocementária (JAC) para padronização do comprimento da raiz em todos os grupos. Uma lima $10 \mathrm{~K}$ foi introduzida até que a ponta fosse visível no forame da raiz. o comprimento de trabalho foi obtido subtraindo-se 0,5 milímetros do comprimento medido. A limpeza e modelagem foram realizados em todos os dentes, inicialmente manualmente com limas $\mathrm{K}$ de até \#35 e, finalmente, com instrumentos rotatórios RaCe (35/06) (FKG Dentaire suíço Produtos Odontológicos, La Chaux-deFonds, Suíça). Dois mililitros de hipoclorito de sódio a 5,25\% e $2 \mathrm{~mL}$ de solução salina foram utilizados como irrigantes entre cada tamanho de lima. Ácido etilenodiaminotetracético (EDTA, RC Ajuda; Prime Produtos Odontológicos, Mumbai, Índia) foi usado como um lubrificante durante a instrumentação, e solução salina foi usada como o enxágüe final para eliminar o efeito dos irrigantes sobre a expansão da guta-percha. Os resultados deste estudo demonstraram uma redução estatisticamente significante na expansão volumétrica de guta-percha durante um período de 30 dias. Os autores concluíram que a expansão volumétrica de gutapercha ocorreu devido ao contato com o eugenol. Um aumento da proporção pó/líquido reduziu a quantidade de eugenol liberado no intervalo de um mês. Portanto, a relação de proporção do cimento em 1:1 (óxido de zinco/eugenol) mostrou menor expansão. 
PAWINSKA et al. (2011) avaliaram comparativamente as propriedades adesivas de obturações em canais radiculares, por meio de teste à resistência de união na interface material-dentina. Os autores utilizaram cinquenta dentes humanos extraídos, unirradiculares que foram preparados com Hero 30.04. Em seguida foram divididos em quatro subgrupos, conforme material obturador e método de obturação: Resilon/Epiphany - termoplástico (IA), Resilon/Epiphany - cone único (IB), guttapercha/Roeko Automix Seal - termoplástico (IIA) e gutta-percha/Roeko Automix Seal - cone único (IIB). Foram obtidas fatias de 1,7 mm de espessura das raízes cortadas perpendicularmente ao longo eixo, e estas submetidas a teste push-out. Os autores concluíram de acordo com resultado estatístico, que o sistema R / E apresentou melhor capacidade de adesão à dentina intra-radicular do que G / RSA e a força de maior adesão foi observado para Resilon / Epiphany - técnica de cone único. E ainda que a resistência de união entre material-dentina foi dependente do tipo de material utilizado e técnica de obturação.

GOLDSTEIN (2011) analisou na literatura evidências hematológicas e toxicológicas relacionadas à controvérsia do formaldeído como uma causa ou não ao câncer hematopoiético em seres humanos. O autor relata que a compreensão do mecanismo biológico pelo qual um produto químico ou agente físico possa provocar câncer, tem sido cada vez mais reconhecida como um importante componente à identificação de carcinógenos humanos. Porém de acordo com outros autores, sem uma clara compreensão do mecanismo pelo qual o formaldeído inalado atinge as células tronco da medula óssea ou sem a associação epidemiológica de exposição ao formaldeído com leucemia, permanece a questão central em saber se o formol deve ser considerado uma conhecida ao invés de uma provável substância leucêmica. Na opinião do autor, é altamente provável que o formaldeído possa 
causar leucemia, mas a evidência atual não é bastante suficientemente forte para justificar a designação dada pela IARC e por revisão de outras organizações como sendo um leucogenico.

COSTA et al. (2011) avaliaram o risco genotóxico na exposição ocupacional ao formaldeído por meio de análise de linfócitos humanos. Os autores afirmam que o formaldeído (FA) é um composto de alta produção mundial, com inúmeras aplicações que vão de produção de resinas a medicamentos. Devido às suas propriedades sensibilizantes, efeitos irritantes e risco potencial de câncer é uma preocupação grande em saúde ambiental. O FA inalado produz genotoxicidade, toxicidade, e câncer em locais distantes sedo classificado pela Agencia Internacional de Pesquisa sobre o Câncer (IARC) desde 2006 como carcinógeno humano (Grupo 1). Os resultados obtidos apontam uma tendência para acúmulo de danos cromossômicos com a duração da exposição ao FA com correlação positiva significante entre freqüência e anos de emprego. Os autores concluíram que com os dados obtidos o risco genotóxico ocupacional devido à exposição ao FA não pode ser excluído, o que, juntamente com implicações de carcinogenicidade humana, enfatiza a necessidade de acompanhar de perto a exposição ao FA. Assim, implementação de medidas de segurança e higiene, bem como boas práticas e campanhas, podem ser crucial para diminuir o risco.

PONGSAVEE (2011) estudou, in vitro, o efeito antiproliferativo do formaldeído e seu efeito citogenético em linfócitos humanos. O autor considerou que o efeito citogenético do formaldeído era caracterizado pela perda cromossômica.O sangue de 30 voluntários foi coletado, heparinizado e tratado com o formaldeído em concentrações de 0,$036 ; 0,072 ; 0,15 ; 0,30 ; 0,576 ; 0,80$ e 1,152 mg/mL, respectivamente, por 24 horas. Os resultados mostraram que todas as 
concentrações de formaldeído originaram efeitos antiproliferativas nos linfócitos humanos. Para avaliação do efeito citogenético, os cromossomos foram encontrados somente nas culturas de linfócitos tratadas com as concentrações de 0,036 e 0,072 $\mathrm{mg} / \mathrm{mL}$ de formaldeído. Nenhum cromossomo foi encontrado nas culturas de linfócitos tratados com o formaldeído nas concentrações de 0,$15 ; 0,3 ; 0,576 ; 0,8$ e $1,152 \mathrm{mg} / \mathrm{mL}$, respectivamente. O autor conclui que o formaldeído tem efeito antiproliferativo e citogenético sobre os linfócitos humanos.

DUONG et al. (2011) em revisão de literatura estudaram a toxicidade do formaldeído na reprodução e no desenvolvimento. Os autores relataram que o formaldeído é produzido endogenamente em todos os organismos vivos, incluindo seres humanos, mas exposição a fontes exógenas onipresentes dentro de casa, ao ar livre, no trabalho, em residências, em alimentos e medicamentos, representa uma ameaça significativa para a saúde pública. É cada vez mais aceito pela International Agency for Research on Cancer (IARC) que o formaldeído é um carcinogênico humano, embora sua toxicidade na reprodução e no desenvolvimento, associada à sua exposição permaneça inconclusiva. Toxicidade descreve a capacidade de uma substância causar efeitos adversos no organismo, como manifestações incluindo aborto espontâneo, natimortos, malformações congênita, baixo peso, partos prematuros e outras anomalias estruturais. Os autores encontraram incidências alteradas de gestações, menstruação anormal e espermatozóides anormais e afirmaram que cada sinal destes pode servir como indicador potencial de toxicidade reprodutiva em humanos. Os mesmos afirmaram que apenas estudos sobre a via inalatória são relevantes, porém a exposição humana oral, tópica e injetável também requer consideração, dada a crescente exposição através destas vias. Assim, os vários meios de exposição ao formaldeído examinados nos estudos em animais 
podem ser relevantes e aplicáveis aos seres humanos. Os autores explicaram que os mecanismos pelos quais o formaldeído é proposto como indutores de toxicidade reprodutiva e do desenvolvimento incluem genotoxicidade, estresse oxidativo, a interrupção da atividade de proteínas, enzimas e hormônios importantes para a maturação do sistema reprodutivo masculino, apoptose, e metilação do DNA. Os autores concluíram que há uma necessidade de mais estudos em animais e humanos examinando se o efeito da exposição ao formaldeído sobre a reprodução e toxicidade. A maioria dos dados atuais vem de estudos com animais e não são claro como estes achados podem ser relevantes para os humanos. Além disso, os estudos com animais variam em meios de contaminação, duração e número de exposição e o tempo de seguimento; tudo o que poderia influenciar no resultado. 


\section{III - Proposição}



O objetivo deste estudo é avaliar, por meio do método colorimétrico de Bailey, se ocorre a liberação de formaldeído por alguns cimentos endodônticos, em momentos distintos, a saber:

. durante a espatulação dos seus componentes, para formar a massa do cimento;

. na massa manipulada, de dois modos diferentes:

a. na água circundante a ela, presente após a espatulação do material e ali mantida pelo lapso temporal correspondente a três vezes o tempo de endurecimento, e

b. na massa endurecida (decorrido o lapso de três vezes o tempo de endurecimento do cimento), mantida em água para extração do formaldeído. 
104 | Proposição 


\section{IV - Materiais e Métodos}



As análises para detecção da liberação de formaldeído foram realizadas no Laboratório de Gerenciamento de Resíduos Odontológicos da Faculdade de Odontologia de Ribeirão Preto (FORP-USP), onde todos os procedimentos químicos foram realizados em conjunto com a Profa ${ }^{a}$ Dr ${ }^{a}$. Débora Fernandes Costa Guedes, química responsável pela metodologia empregada e análise dos resultados obtidos nesta pesquisa.

\section{Equipamentos e materiais}

- Agitador com Aquecedor Magnético (Cientec Equipamentos para Laboratório);

- Aparelho deionizador por Osmose Reversa 10L / h - Q842 (Quimis ${ }^{\circledR}$ );

- Aparelho de Ultrassom ALTsoni Clean 3PA T-14 (Odontobrás);

- Balança Analítica Mettler Toledo AG245;

- Barra de agitação magnética;

- Câmara de fibra desenvolvida durante a pesquisa para preparar as resinas e coletar o formaldeído liberado durante a espatulação;

- Cronometro Digital Casio Hs-3 Basic Trainer V.1.2.0;

- Cubetas de quartzo (Quimis ${ }^{\circledR}$ );

- Espectrofotômetro UV-VIS Duplo feixe com Varredura Q798UVDB (Quimis ${ }^{\circledR}$ );

- Estufa para Cultura, ECB 1.3 Digital (Odontobrás);

- Micropipetas (100 $\mu \mathrm{L}$ e $5000 \mu \mathrm{L})\left(\right.$ Transferpette $\left.^{\circledR} \mathrm{S}\right)$;

- Microsseringa de $2500 \mu \mathrm{L}$ (Hamilton Co. Reno. Nevada Gastight \#100² - $2 \mathrm{~mL}$ );

- pHmetro NA 2000 microprocessado (Analion);

- Vidraria de laboratório $\left(\right.$ Pyrex $\left.^{\circledR}\right)$ 


\section{Reagentes}

Tabela I. Reagentes utilizados no trabalho apresentavam grau de pureza analítica.

\begin{tabular}{lcc}
\hline Produto (Fabricante) & Fórmula & Lote \\
\hline Ácido Cítrico (Sigma Reagent Grade) & $\mathrm{C}_{6} \mathrm{H}_{8} \mathrm{O}_{7}$ & $115 \mathrm{~K} 0095$ \\
Ácido Clorídrico $37 \%$ (Synth) & $\mathrm{HCl}$ & 55112 \\
Formaldeído Estabilizado 37\% (Chemco) & $\mathrm{H}_{2} \mathrm{CO}$ & 22114 \\
Fosfato dissódico (Mallinckrodt Gen AR) & $\mathrm{Na}_{2} \mathrm{HPO}_{4} .7 \mathrm{H}_{2} \mathrm{O}$ & $7393 \mathrm{KLMC}$ \\
& & \\
Peróxido de Hidrogênio 30 \% (Fmaia) & $\mathrm{H}_{2} \mathrm{O}_{2}$ & 39354 \\
& & \\
Diidrocloreto de parafenilenodiamina & $\mathrm{C}_{6} \mathrm{H}_{8} \mathrm{~N}_{2}$ & - \\
& & \\
\hline
\end{tabular}

\section{Seleção dos cimentos}

Para o presente estudo foram selecionados os cimentos endodônticos AH Plus (Dentsply Detrey, Konstanz, Alemanha; Lotes 0812000972 e 0811001841 ), Sealer 26 (Dentsply, RJ,Brasil Indústria e Comércio LTDA; Lote 716027), ThermaSeal Plus Ribbon (Dentsply, Tulsa Dental Specialties, Alemanha; Lote 1006001836), MetaSEAL (Parkell, Farmingdale Inc., Nova lorque, EUA; Lotes VG15 e EE11), Epiphany SE (Pentron Clinical, WallingFord, CT, EUA; Lotes 153296 e 168778), EndoREZ (Ultradent Products Inc., South Jordan, Utah, EUA; Lote B3TG6), Apexit Plus (IvoclarVivadent, Schaan, Liechtenstein, Alemanha; Lote K49853), Sealapex (SybronEndo, Sybron Dental Specialties, Glendona, CA, EUA; Lote 8- 
1319), MTA Fillapex (Angelus SA, Paraná, Brasil; Lote 17584), Endofill (Dentsply, Brasil Indústria e Comércio Ltda, Rio de Janeiro, RJ, Brasil; Lote 099677B), CRCS (Hygenic, Coltènewhaledent, EUA; Lotes 0-1130), Pulp Canal Sealer (Kerr Corporation, Orange, CA, EUA; Lote 0-1128), Endomèthasone N (Septodont, SaintMaur-des-Fossés, França; Lote 48816AA) e BC Sealer (EndoSequenceBrasseler, Georgia, EUA; Lote 10002SP). As composições dos cimentos estão descritas na Tabela II.

\section{Obtenção das Amostras}

Para obtenção das amostras, foi utilizada uma câmara de fibra de 40 x 27 x $17 \mathrm{~cm}$ (sistema fechado), onde os cimentos foram espatulados, nas suas respectivas proporções pó/líquido e pasta/pasta de acordo com as recomendações de cada fabricante com exceção do cimento BC Sealer (pasta única). Obtiveram-se três amostras para cada tipo de cimento estudado.

Nesta câmara de fibra, foram dispostos recipientes de vidro com $10 \mathrm{ml}$ de água deionizada para captação de eventual formaldeído liberado durante o tempo de espatulação (Figura 1). As primeiras amostras analisadas foram adquiridas pela coleta de todo o volume da água utilizada, com seringa descartável de $10 \mathrm{ml}$, após tempo de espatulação de cada cimento.

Os cimentos manipulados foram acomodados em discos de teflon medindo 8 $\mathrm{mm}$ de diâmetro por $2 \mathrm{~mm}$ de altura, sobre lâminas de vidro de $26 \times 38 \times 8 \mathrm{~mm}$ envoltas de papel celofane. Os conjuntos foram fixados individualmente em suportes plásticos medindo $20 \mathrm{~mm}$ de diâmetro por $33 \mathrm{~mm}$ de altura e mantidos suspensos em recipientes plásticos contendo $10 \mathrm{ml}$ de água deionizada (Figura 2A). 
Tabela II. Composição dos cimentos endodônticos.

\begin{tabular}{ll}
\hline Cimento & Composição \\
\hline AH Plus & Pasta A (epóxica): Resinas epóxicas bisfenol-A e bisfenol-F (Éter de diglicidil- \\
& bisfenol), tungstato de cálcio, óxido de zircônio, sílica, pigmentos de óxidos de \\
& ferro. Pasta B (amina): Amina 1-adamantana, N, N-dibenzil-5 \\
& oxanonandiamina-1, 9, TCD-diamina, tungstato de cálcio, óxido de zircônio, \\
& sílica, óleo de silicone.
\end{tabular}

Sealer 26

Pó: Trióxidode bismuto, hidróxido de cálcio, hexametileno tetramina, dióxido de titânio. Resina: Epóxi bisfenol.

ThermaSeal Plus RIBBON

MetaSEAL

Epiphany SE

EndoREZ

Apexit Plus

Sealapex

MTA Fillapex

Endofill

CRCS

Pulp Canal Sealer

Endomèthasone $\mathrm{N}$

BC Sealer
Paste A: Resinas epóxicas bisfenol-a e bisfenol-f, tungstato de cálcio, óxido de zircônio, sílica, pigmentos de óxido de ferro. Paste B: Dibenzildiamina, aminoadamantano, triciclodecano-diamina, tungstato de cálcio, óxido de zircônio, sílica, óleo de silicone.

Pó: Óxido de zircônio, sílica, amorfa, iniciador de polimerização. Líquido: Monometacrilato (HEMA), dimetacrilato (4-META).

Primer: AMPS, monômero hidrofílico.

Sealer: EBPADMA, HEMA, BIS-GMA, partículas de carga de sulfato de bário, vidro tratado com silano, sílica, hidróxiapatita, silicato (Ca-Al-F), oxicloreto de bismuto com aminas, óxido de alumínio, peróxido, foto-iniciador, estabilizadores e pigmentos.

Catalisador: (paraToluimino)dietanol, trietilienoglicol dimetacrilato.

Base: UDMA.

Sais de cálcio (hidróxido, óxido, fosfato), colofônia hidrogenada, di-salicilato, sais de bismuto (óxido, carbonato), dióxido de silício altamente disperso (silanizado) ealquil-éster do ácido fosfórico.

Catalisador: Silicato de isobutila, sílica pirogênica (dióxido de silício), trióxidode bismuto, pigmento de dióxido de titânio. Base: resina $\mathrm{N}$-etil tolueno sulfonamida, sílica pirogênica (dióxido de silício), óxido de zinco, óxido de cálcio

Resina de salicilato, resina diluente, resina natural, óxido de bismuto, sílica nanoparticulada, trióxido agregado mineral, pigmentos.

Pó: Óxido de zinco, resina hidrogenada, subcarbonato de bismuto, sulfato de bário e borato de sódio. Líquido: Eugenol e óleo de amêndoas doces

Pó: Óxido de zinco, éster de resinato hidrogenado, sulfato de bário, hidróxido de cálcio, subcarbonato de bismuto.Líquido: Eugenol, eucaliptol.

Pó: Óxido de zinco, pó de prata; timol iodado e resina dimérica ácida. Líquido: 4-Alil-2-Metoxifeno; resina balsâmica.

Pó: Acetato de hidrocortisona, di-iodo de ditimol, sulfato de bário, óxido de zinco e estreatato de magnésio. Líquido: eugenol

Óxido de zircônio, silicatos de cálcio, fosfato monobásico de cálcio, hidróxido de cálcio, agentes de preenchimento e espessantes. 


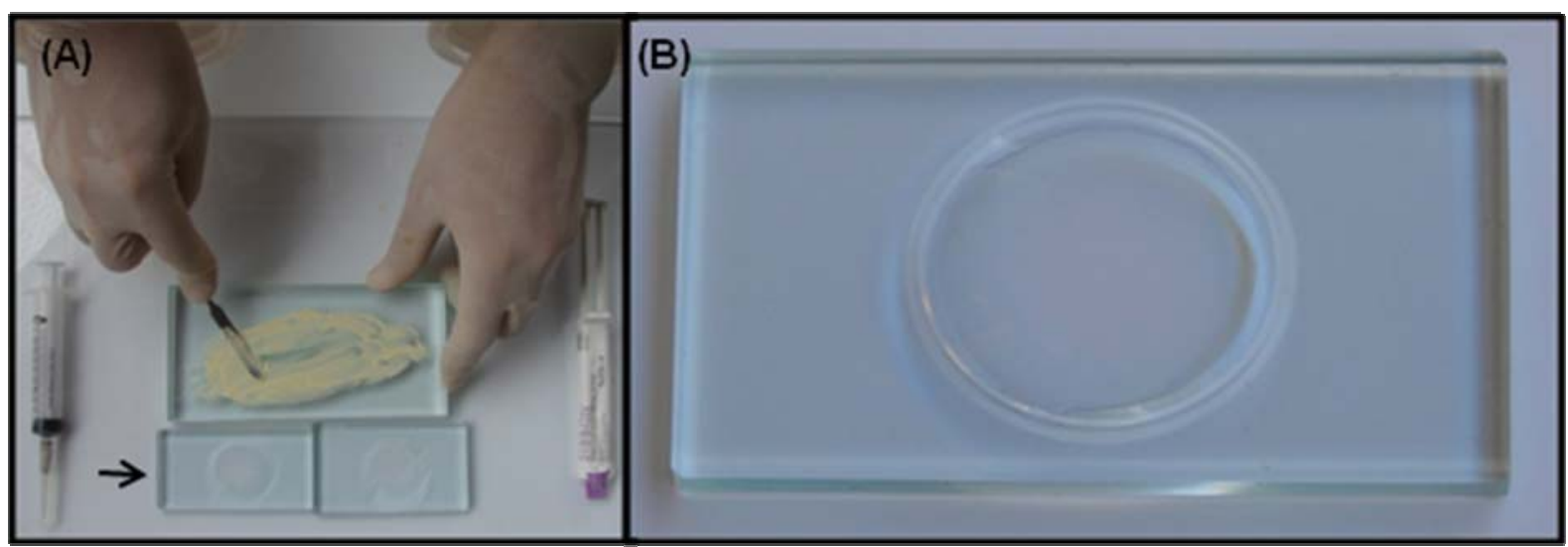

Figura 1. (A) Espatulação do cimento em câmara de fibra contendo recipientes; (B) Detalhe do vidro (seta em A) contendo água deionizada.

Os recipientes foram vedados com tampas rosqueáveis, retirados da câmara de fibra e armazenados em estufa $\left(37^{\circ} \mathrm{C}, 100 \%\right.$ umidade relativa) durante três vezes o tempo de endurecimento de cada cimento testado. Após, coletou-se a água deionizada contida em cada recipiente para análise em relação à presença de formaldeído.

Os cimentos foram então retirados dos discos de teflon e inseridos individualmente em outro recipiente de plástico com $10 \mathrm{ml}$ de água deionizada, mantidos em cuba ultrassônica por 15 minutos para extração de possível formaldeído residual (Figura 2B), e, uma vez removida a água, procedeu-se à sua análise.

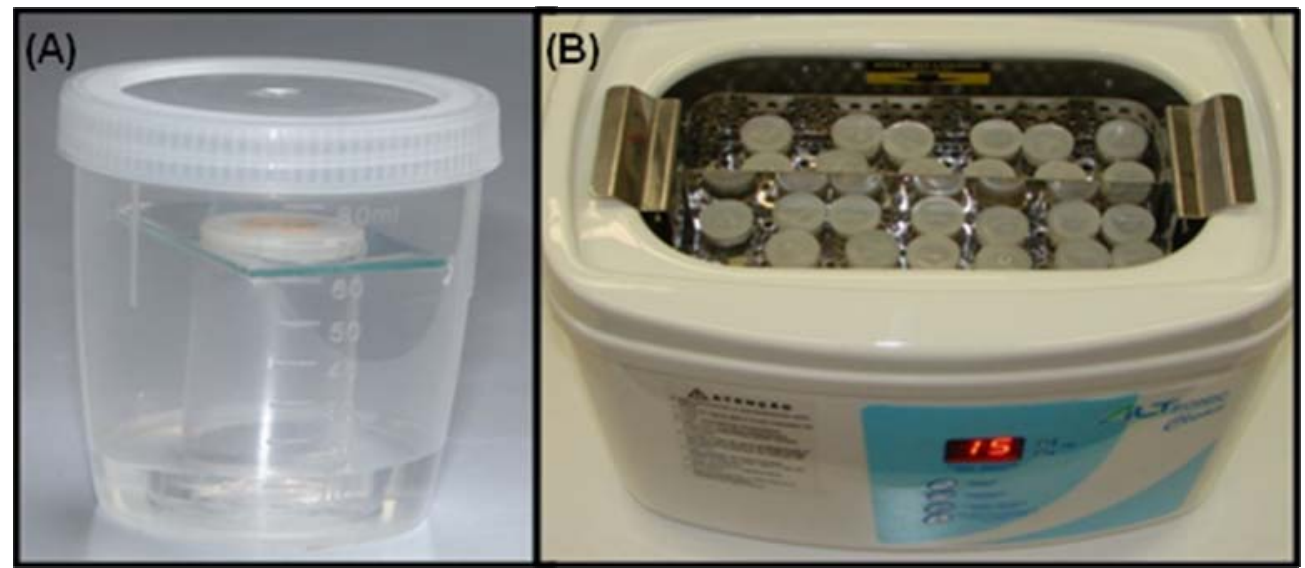

Figura 2. (A) Recipiente plástico com $10 \mathrm{~mL}$ de água deionizada contendo cimento em disco de teflon suspensos; (B) Cimentos em frascos com $10 \mathrm{~mL}$ de água deionizada mantidos em cuba ultrassônica por quinze minutos. 


\section{Preparo das soluções utilizadas na determinação do formaldeído}

Para a determinação do formaldeído, utilizou-se método colorimétrico, baseado na oxidação da parafenilenodiamina pelo peróxido de hidrogênio. Neste sentido, para construção da curva de calibração, foram utilizadas as soluções de fosfato dissódico/ácido cítrico (tampão), diidrocloreto de parafenilenodiamina e peróxido de hidrogênio $30 \%$.

Para o preparo da solução tampão, misturou-se uma solução de ácido cítrico $0,1 \mathrm{~mol} . \mathrm{L}^{-1}(17,647 \mathrm{~g} \mathrm{em} 840 \mathrm{~mL}$ de água deionizada) à solução de fosfato dissódico 0,3 mol. $\mathrm{L}^{-1}$ (41,329 g em $1160 \mathrm{~mL}$ de água deionizada). $\mathrm{O} \mathrm{pH}$ aferido da solução final foi 5.6, armazenando-se em frasco escuro de $2 \mathrm{~L}$, à temperatura ambiente (ASSUMPÇÃO \& MORITA, 1968).

Para o preparo da solução de diidrocloreto de parafenilenodiamina a $1 \%$ foi necessária prévia purificação da substância por meio da dissolução do composto e sua recristalização. O composto apresentava coloração acastanhada característico de sua decomposição. Para a dissolução, utilizou-se solução diluída de $\mathrm{HCl}(60 \mathrm{~mL}$ de $\mathrm{HCl}$ e $40 \mathrm{~mL}$ de água deionizada) e $2 \mathrm{~g}$ de $\mathrm{SnCl}_{2}$ sob aquecimento. Após o aquecimento foi adicionado carvão ativado e igual volume de $\mathrm{HCl}$ concentrado para a remoção de impurezas. O aquecimento foi mantido até que se solubilizasse todo o diidrocloreto de parafenilenodiamina. Com a solução ainda quente, foi necessário filtrá-la para a retirada do carvão ativo que foi adicionado na etapa anterior da purificação. A seguir, a solução foi resfriada em banho de gelo e sal. Os cristais formados apresentavam cor branca, característico da substancia pura, e foram então filtrados em papel de filtro, lavados com pequena quantidade de $\mathrm{HCl}$ e secos a vácuo, em dessecador, sobre $\mathrm{NaOH}$, por cerca de 48 horas. 
A substância purificada permaneceu em freezer, à temperatura de $-17{ }^{\circ} \mathrm{C}$. Para ser utilizada no preparo das soluções ao longo do experimento, realizava-se sua dissolução em água deionizada, $(0,5 \mathrm{~g}$ de cristais da substância em balão volumétrico de $50 \mathrm{~mL}$ ), transferindo-se para um recipiente de vidro envolto com papel alumínio. A solução de diidrocloreto de parafenilenodiaminatorna em contato com o ar torna-se amarelada e altera a leitura colorimétrica. Para eliminar esse possível erro na leitura, preparava-se a solução no momento em que seria utilizada, sendo que o volume de $50 \mathrm{~mL}$ foi estabelecido em função de piloto realizado, tendo se revelado suficiente para as leituras relativas a um dia de análise.

O terceiro reagente, peróxido de hidrogênio $\left(\mathrm{H}_{2} \mathrm{O}_{2}\right.$ a $\left.30 \%\right)$, foi adquirido com qualidade P.A. e conservado em geladeira $\left(5^{\circ} \mathrm{C}\right)$.

\section{Determinação da Curva de Calibração de Formaldeído}

Para quantificar o formaldeído nas amostras analisadas, foi determinada uma curva de calibração a partir de uma solução padrão de formaldeído 37 \% que foi diluída para obtenção das concentrações de 0,5, 1,0, 1,5, 2,0 mg/L.

Após dosagem das soluções em balões volumétricos, adicionaram-se os reagentes na ordem descrita no item 7 , e imediatamente após a adição de $\mathrm{H}_{2} \mathrm{O}_{2}$, os balões volumétricos foram tampados, permanecendo em repouso por 20 minutos, e logo após submetido a leitura em espectrofotômetro com varredura entre 250 a 700 $\mathrm{nm}$.

As espectrofotometrias das curvas de calibração para a quantificação do formaldeído nas concentrações $0,5,1,0,1,5$ e 2,0 mg/L podem ser visualizados na 
Figura 3. Como foi possível detectar dois comprimentos de onda ( $\lambda=326$ e $462 \mathrm{~nm}$ ), realizaram-se os cálculos de regressão linear para cada um deles (Figura 4).

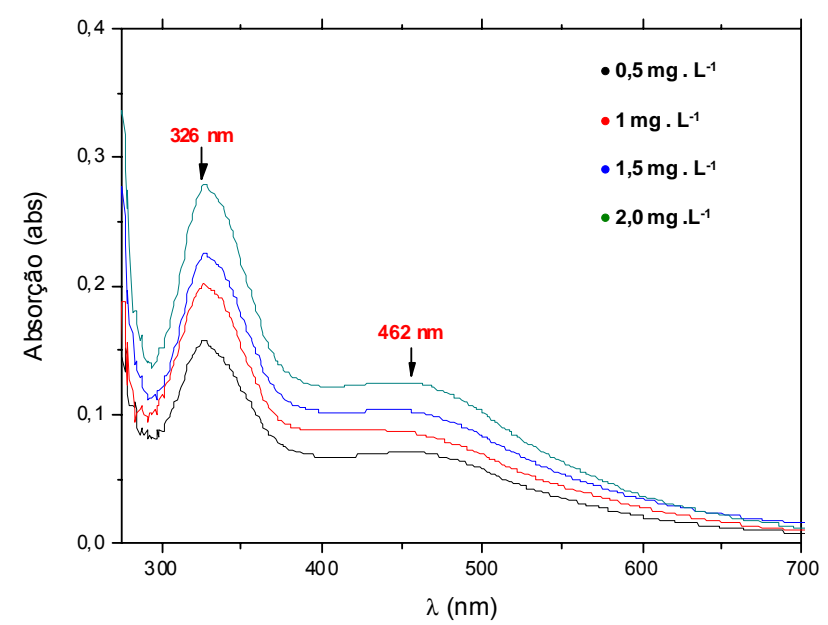

Figura 3. Curva de calibração para formaldeído $(\lambda$ $=326$ e $462 \mathrm{~nm}$ ).
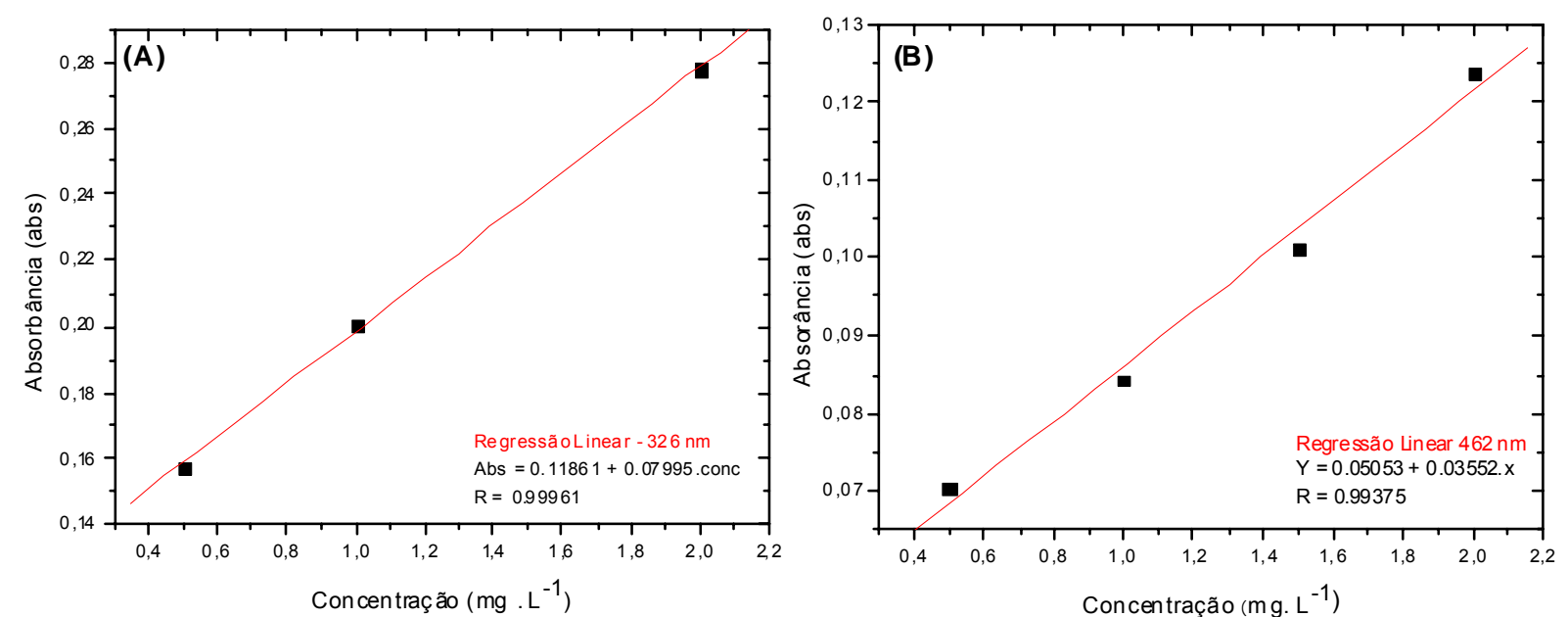

Figura 4. Regressão linear para os comprimentos de onda ( $\lambda$ ) de $326 \mathrm{~nm}(A)$ e $462 \mathrm{~nm}(B)$.

Algumas análises prévias apresentaram concentração de altos valores de formaldeído, os quais ultrapassaram àqueles utilizados para a construção da curva de calibração realizada. Dessa forma, fez-se necessária outra calibração com valores de concentração próximos aos encontrados experimentalmente. A Figura 5 apresenta a nova curva de calibração com valores de concentração $8,10,12$ e 15 mg. $\mathrm{L}^{-1}$; o comprimento de onda encontrado foi $334 \mathrm{~nm}$. Realizaram-se cálculos de regressão linear para esse comprimento de onda (Figura 6). 


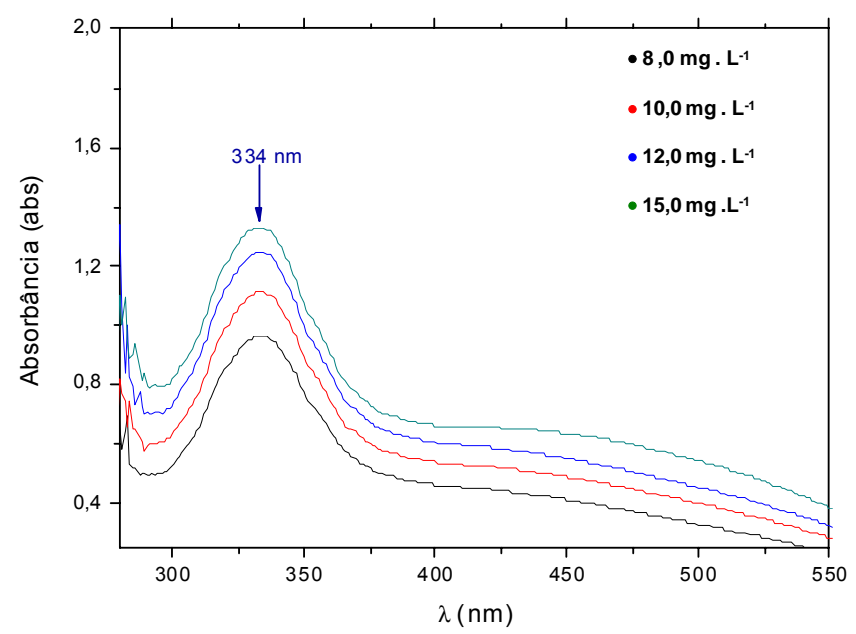

Figura 5. Curva de calibração para formaldeído $(\lambda$ $=334 \mathrm{~nm}$ ).

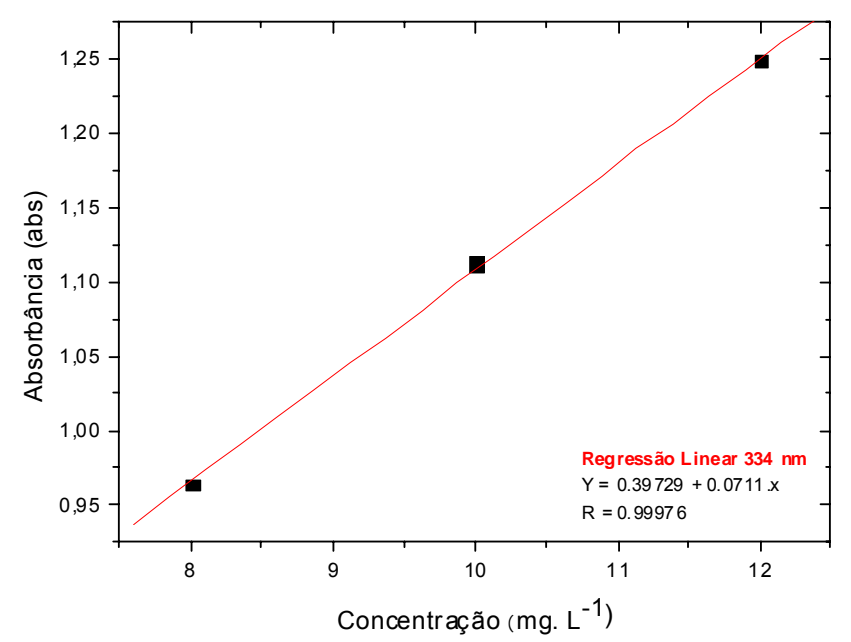

Figura 6. Regressão linear para o comprimento de onda indicado.

\section{Metodologia Empregada para a Detecção de Formaldeído}

A análise da liberação do formaldeído foi realizada por meio do método colorimétrico de BAILEY \& RANKIN. Foram estipuladas três oportunidades para se detectar a presença desta substância, com a sua extração em solução aquosa: (1) após a espatulação do material, (2) durante o lapso temporal correspondente a três vezes o tempo de endurecimento da massa do cimento, e (3) após o lapso temporal correspondente a três vezes o tempo de endurecimento da massa do cimento. 
Para o procedimento analítico sugerido pelo método, adicionam-se, reagentes em frascos volumétricos de $100 \mathrm{~mL}$. Porém devido à pequena quantidade do volume das amostras adquiridas em cada oportunidade proposta no experimento, optou-se por trabalhar com balões volumétricos de $50 \mathrm{~mL}$, utilizando-se a metade do volume de cada reagente.

Primeiramente foi realizada uma leitura controle, por meio da mistura de água deionizada aos três reagentes. Em seguida a cada uma das soluções colidas no experimento, em balões volumétricos no volume de $10 \mathrm{~mL}$, foram adicionados, sequencialmente, $5,0 \mathrm{~mL}$ da solução tampão, $0,5 \mathrm{~mL}$ da solução de diidrocloreto de parafenilenodiamina e $2,5 \mathrm{~mL}$ de peróxido de hidrogênio.

O volume de $50 \mathrm{~mL}$ de cada recipiente foi atingido pela adição de água deionizada.

Cada amostra era analisada cronometradamente 20 minutos após a adição o peróxido de hidrogênio, este é o tempo necessário para a ação do formaldeído acelerando a reação de oxidação da parafenilenodiamina (Figura 7).

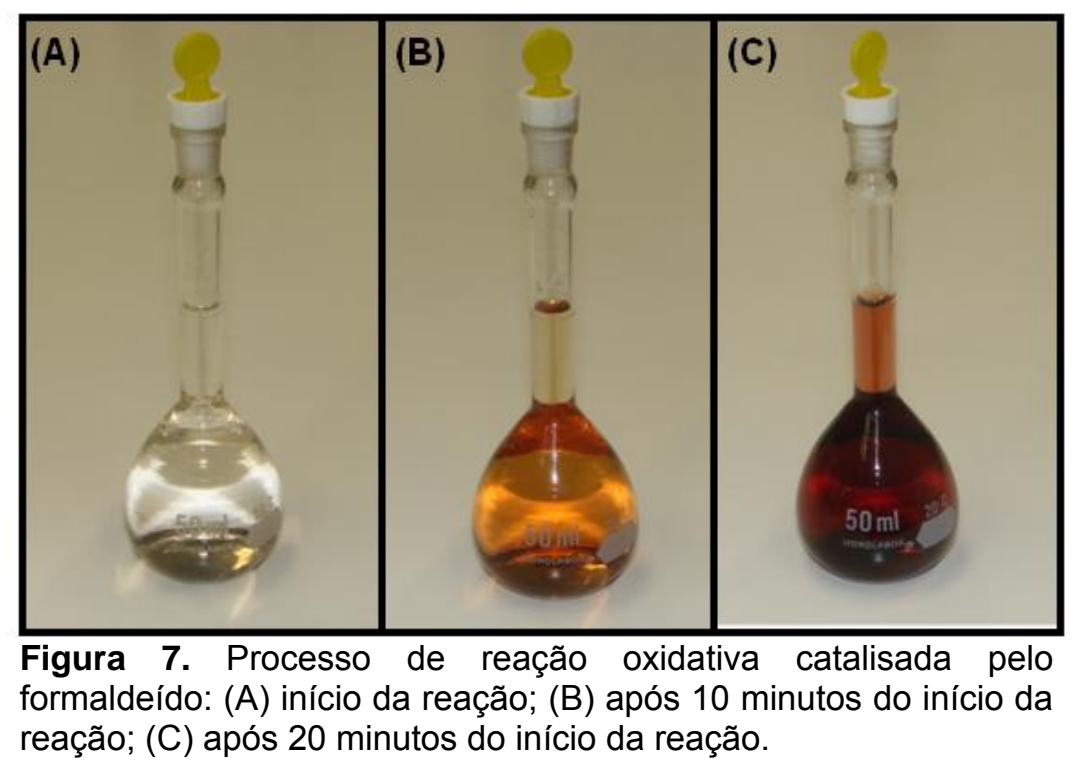


Para a leitura das amostras, utilizou-se espectrofotômetro duplo feixe com varredura e cubeta de quartzo de caminho óptico de $1,0 \mathrm{~cm}$ (Quimis). Os comprimentos de onda que indicaram a presença de formaldeído foram de 326, 334 e $462 \mathrm{~nm}$, encontrados durante calibração do aparelho (Figura 8).

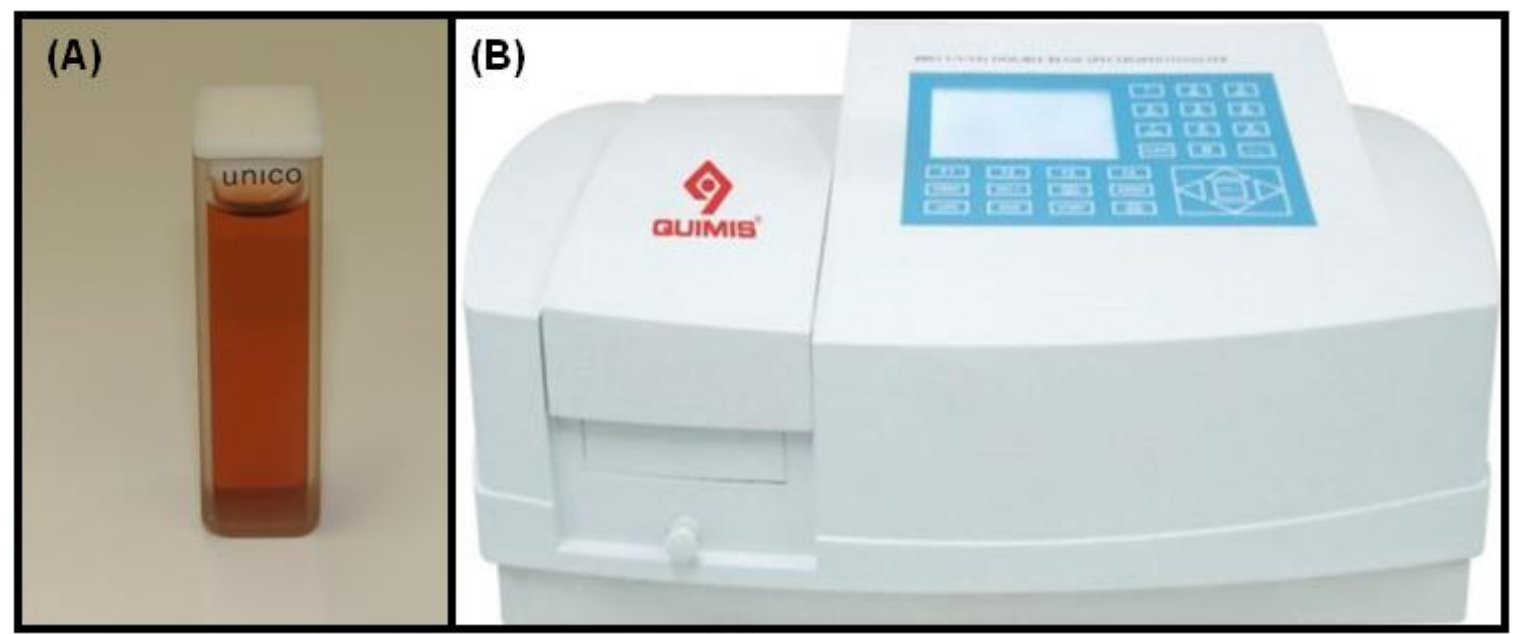

Figura 8. Análise espectrofotométrica. (A) Cubeta de quartzo com solução para leitura; (B) Espectrofotômetro UV-VIS duplo feixe com varredura para análise das soluções. 
118 | Materiais e Métodos 


\section{V-Resultados}



Os cimentos endodônticos foram ordenados para análise (qualitativa e quantitativa) seguindo uma distribuição por em grupos conforme Tabela III.

Tabela III. Grupos de cimentos.

\begin{tabular}{|c|c|c|c|c|}
\hline \multicolumn{5}{|c|}{ Classificação dos Grupos } \\
\hline Resina Epóxica & $\begin{array}{c}\text { Resina } \\
\text { Polimetacrilato }\end{array}$ & $\begin{array}{l}\text { Hidróxido de } \\
\text { Cálcio }\end{array}$ & ZnO I Eugenol & Cerâmico \\
\hline $\begin{array}{c}\text { AH Plus } \\
\text { Sealer } 26 \\
\text { ThermaSeal Plus }\end{array}$ & $\begin{array}{l}\text { Epiphany } \\
\text { MetaSeal } \\
\text { EndoREZ }\end{array}$ & $\begin{array}{l}\text { Apexite Plus } \\
\text { Sealapex } \\
\text { MTA Fillapex }\end{array}$ & $\begin{array}{c}\text { Endofill } \\
\text { CRCS } \\
\text { Pulp Canal Sealer } \\
\text { Endomèthasone N }\end{array}$ & BC Sealer \\
\hline
\end{tabular}

\section{Capacidade de coleta das amostras de formaldeído no sistema proposto}

Fez-se análise direta da solução padrão de formaldeído com concentração 10 mg. $\mathrm{L}^{-1}$ (Figura 9, curva rosa). As porcentagens de adsorção da água em cada momento medido foram calculadas considerando como 100 \% a absorbância medida nesta solução padrão. Após a análise das absorbâncias nos momentos propostos (Figura 8), foram obtidos os valores do teor de formaldeído de $78 \%$ (espatulação), 70 \% (tempo de endurecimento) e 89 \% (extração do cimento). Estes valores foram utilizados para a quantificação do formaldeído encontrado nas amostras dos cimentos endodônticos avaliados. 


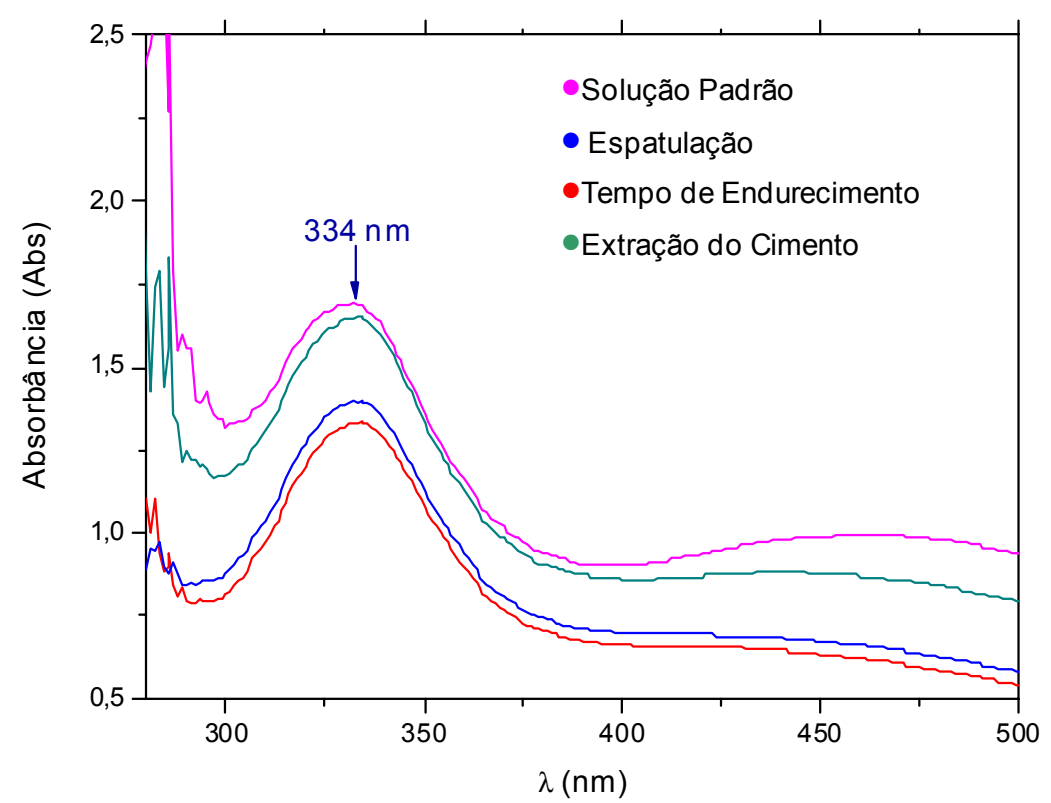

Figura 9. Espectrofotometria das soluções testadas para a extração do formaldeído.

\section{Análises da liberação de formaldeído}

\subsection{Cimentos à base de resina epóxica}

No cimento AH Plus (Figura 10) detectou-se maior liberação de formaldeído no tempo de endurecimento $\left(4.44 \mathrm{mg} \cdot \mathrm{L}^{-1}\right)$. Tanto na espatulação, quanto na extração do cimento, encontrou-se formaldeído, porém em níveis abaixo do limite de detecção, impossibilitando sua quantificação.

No cimento Sealer 26 (Figura 11), a presença de formaldeído foi detectada e a maior concentração liberada foi durante o tempo de espatulação $7,40 \mathrm{mg} \cdot \mathrm{L}^{-1}$. Para os outros dois momentos analisados, também se encontrou formaldeído em menores quantidades e não foi possível sua quantificação. 


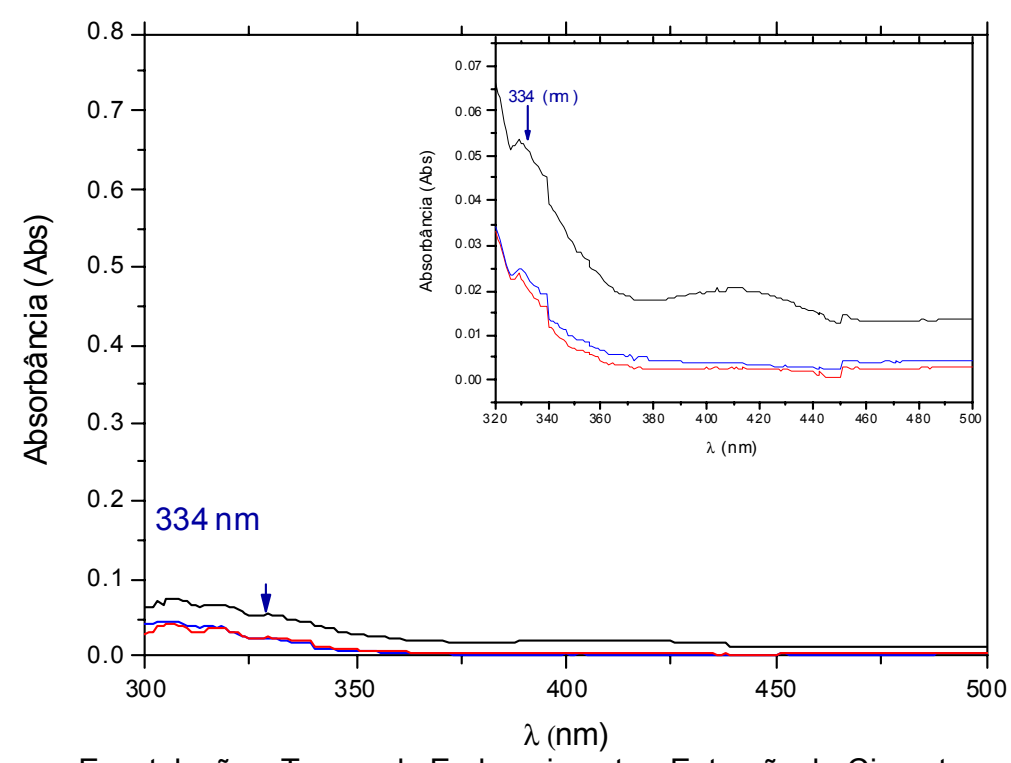

- Espatulação • Tempo de Endurecimento • Extração do Cimento

Figura 10. Espectrograma do cimento endodôntico AH Plus e ampliação apresentando a localização do pico referente ao formaldeído.

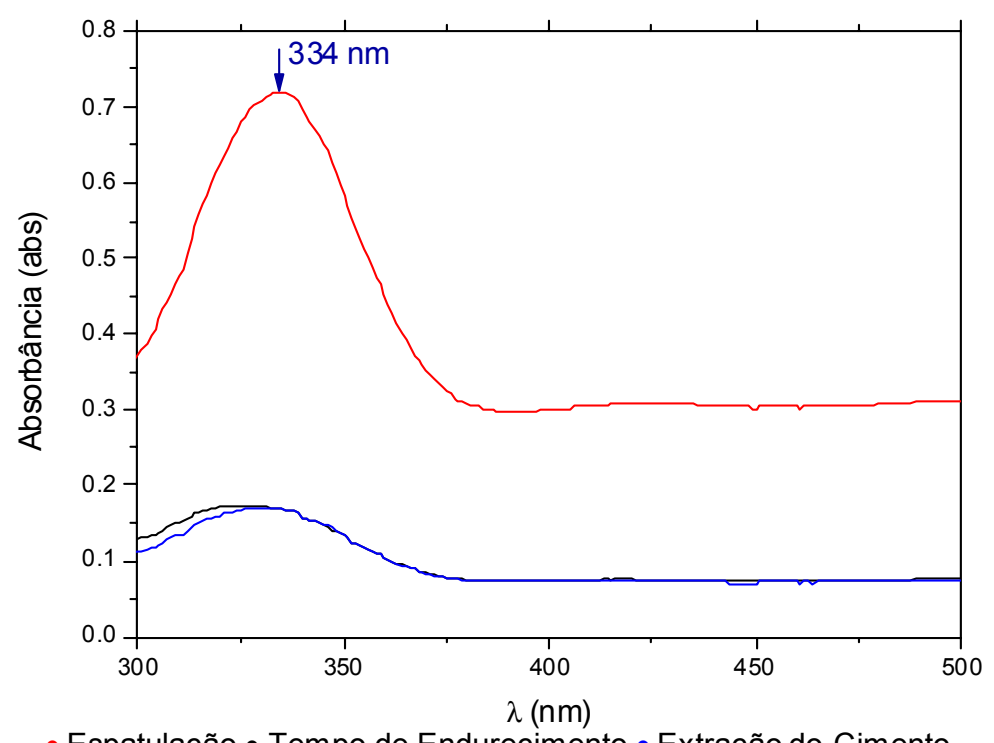

- Espatulação • Tempo de Endurecimento • Extração do Cimento

Figura 11. Espectrograma do cimento endodôntico Sealer 26 nos três momentos analisados. 
No cimento ThermaSeal Plus (Figura 12) foi detectado formaldeído em quantidade abaixo do limite de detecção. A liberação de formaldeído foi praticamente constante nos três períodos analisados.

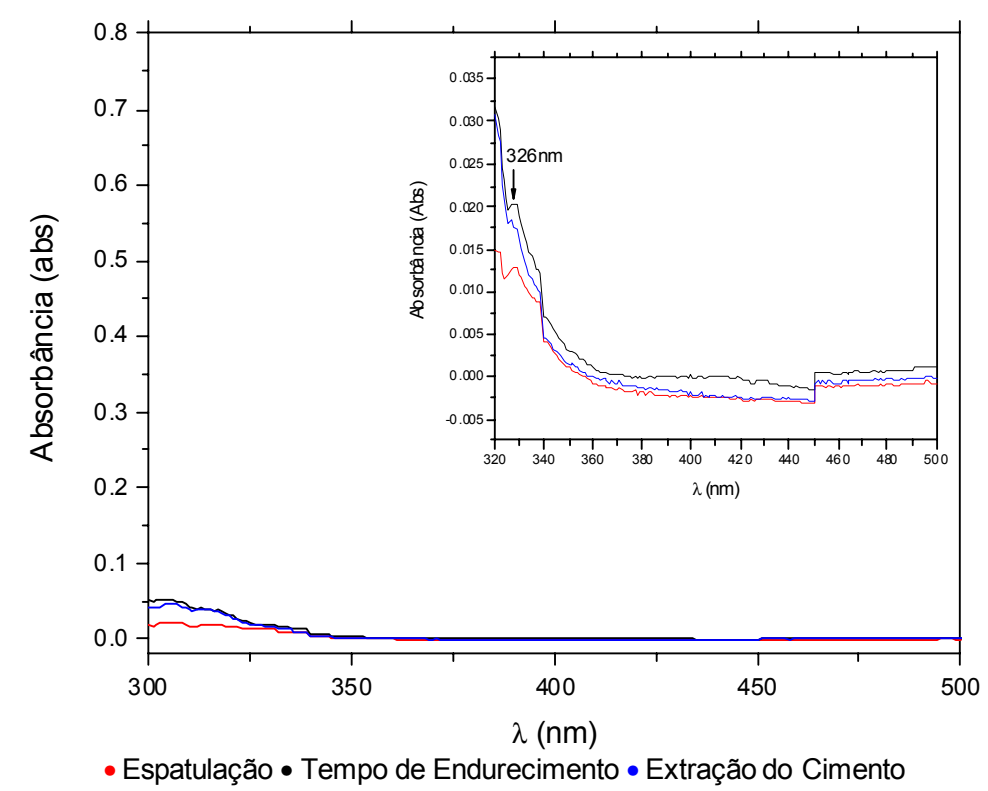

Figura 12. Espectrograma do cimento endodôntico ThermaSeal Plus nos três momentos analisados.

\subsection{Cimentos de Polimetacrilato}

Para os polímeros de polimetacrilato MetaSeal (Figura 13) e Epiphany (Figura 14) não houve geração de formaldeído nos três momentos analisados. No caso do cimento EndoREZ (Figura 15), detectou-se formaldeído durante os três momentos analisados sendo que a maior quantidade foi observada durante o tempo de endurecimento. 


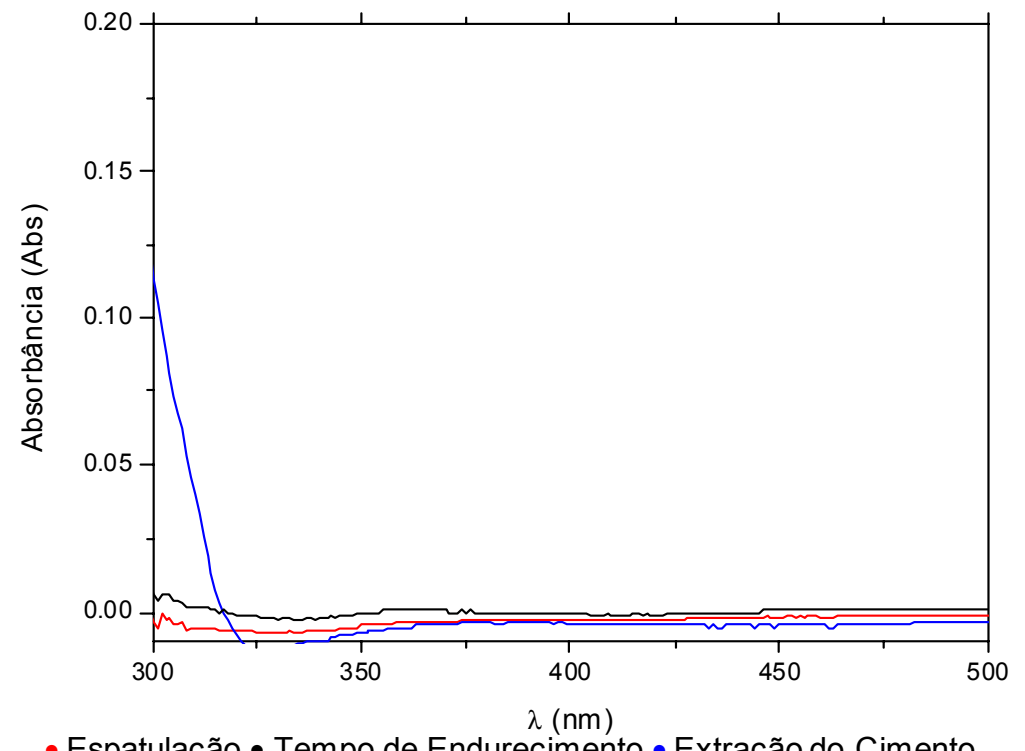

- Espatulação • Tempo de Endurecimento • Extração do Cimento

Figura 13. Espectrograma do cimento endodôntico MetaSeal nos três momentos analisados.

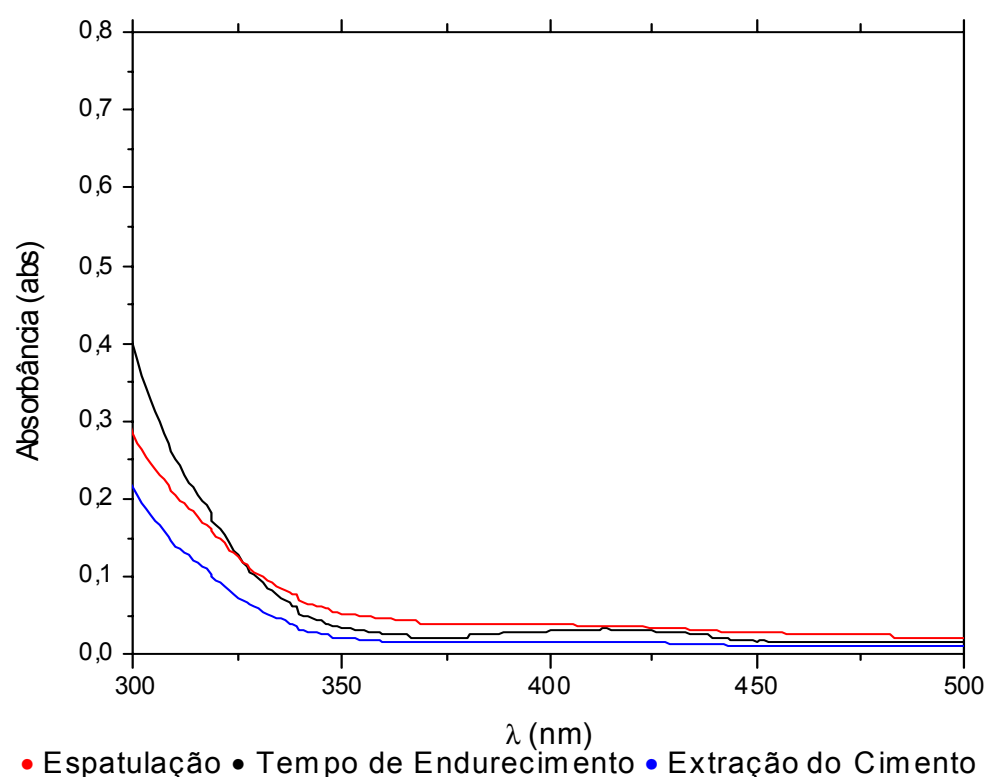

Figura 14. Espectrograma do cimento endodôntico Epiphany nos três momentos analisados. 


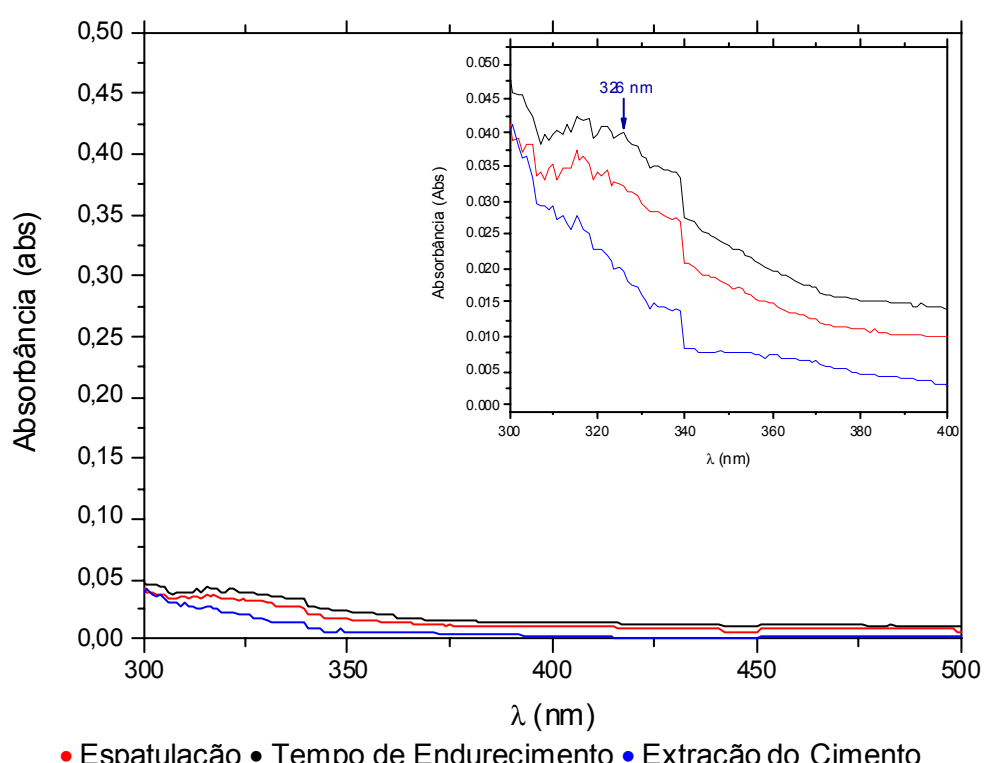

Figura 15. Espectrograma do cimento endodôntico EndoREZ nos três momentos analisados.

\subsection{Cimentos à base de hidróxido de cálcio}

Para os cimentos Apexit Plus (Figura 16), Sealapex (Figura 17) e MTA Fillapex (Figura 18) não houve geração de formaldeído nos três momentos analisados.

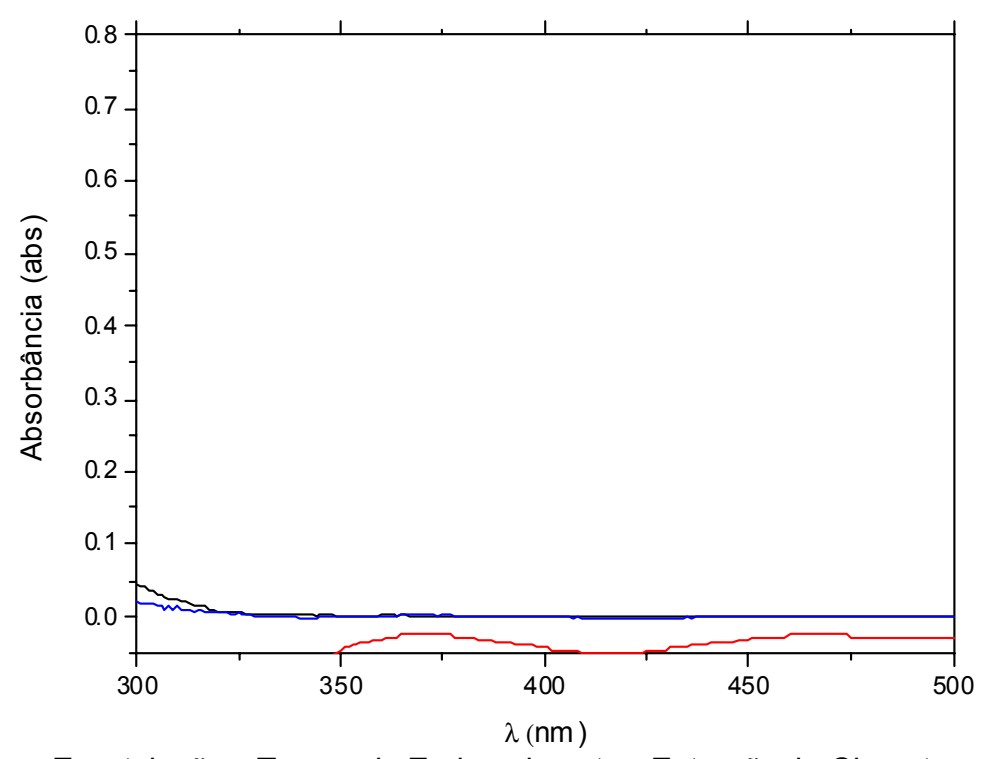

- Espatulação • Tempo de Endurecimento • Extração do Cimento

Figura 16. Espectrograma do cimento endodôntico Apexit Plus nos três momentos analisados. 


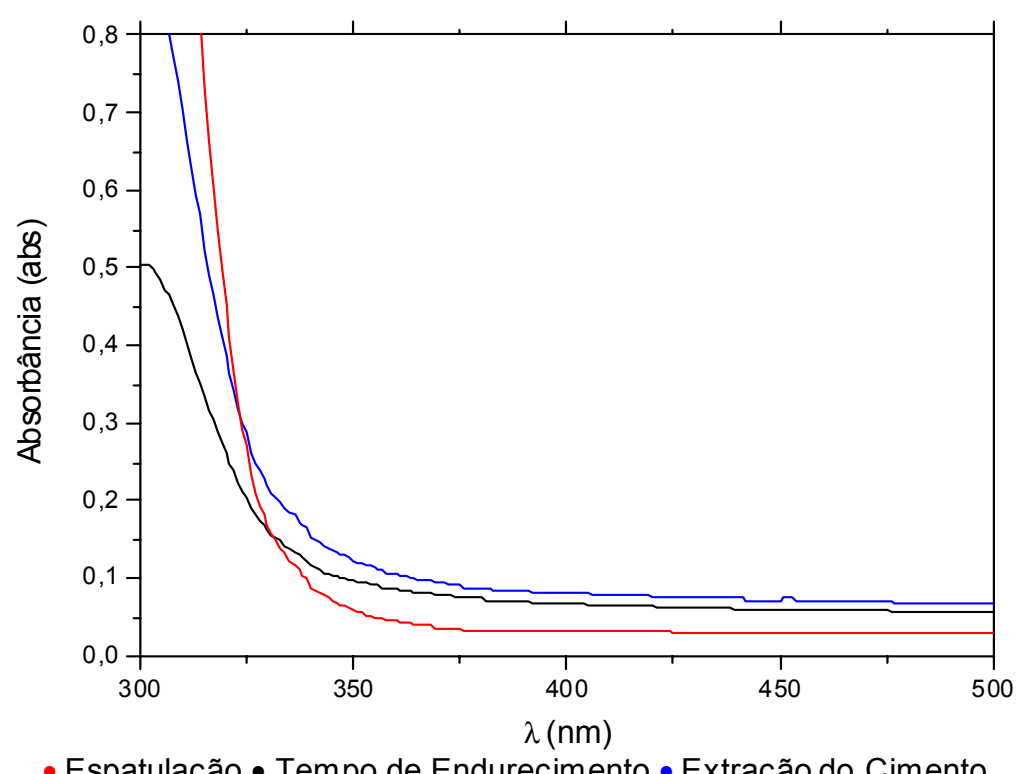

- Espatulação • Tempo de Endurecimento • Extração do Cimento

Figura 17. Espectrograma do cimento endodôntico Sealapex nos três momentos analisados.

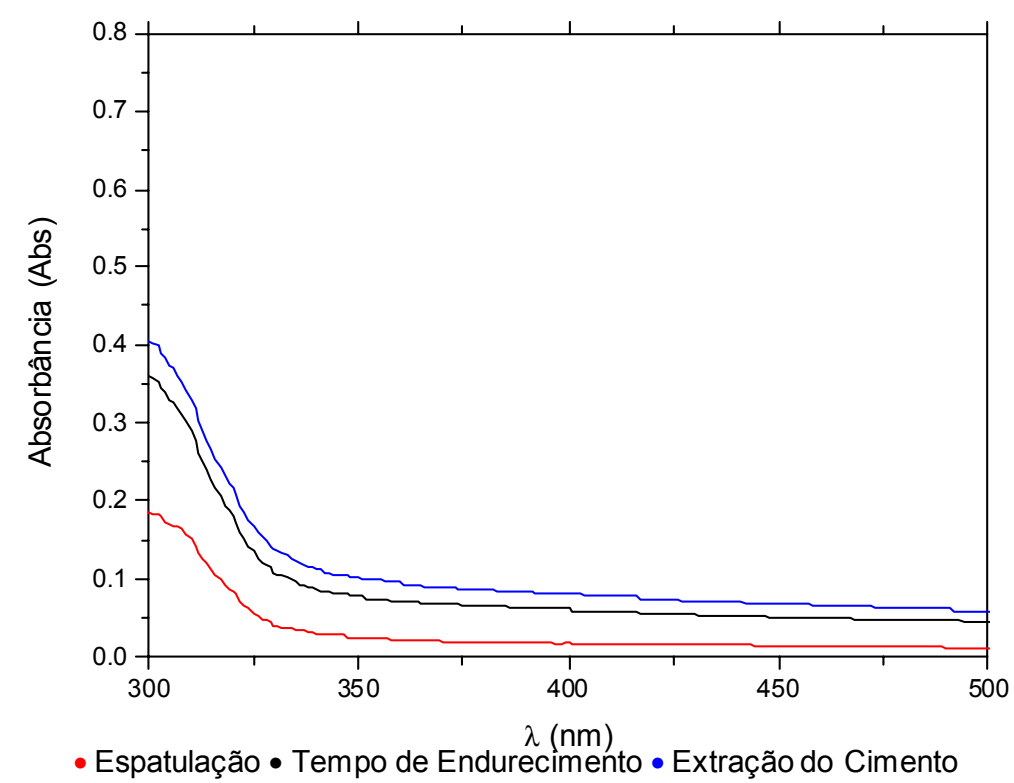

Figura 18. Espectrograma do cimento endodôntico MTA Fillapex nos três momentos analisados. 


\subsection{Cimentos à base de óxido de zinco e eugenol}

Para os cimentos Endofill (Figura 19), CRCS (Figura 20) e Pulp Canal Sealer

(Figura 21) não houve geração de formaldeído nos três momentos analisados.

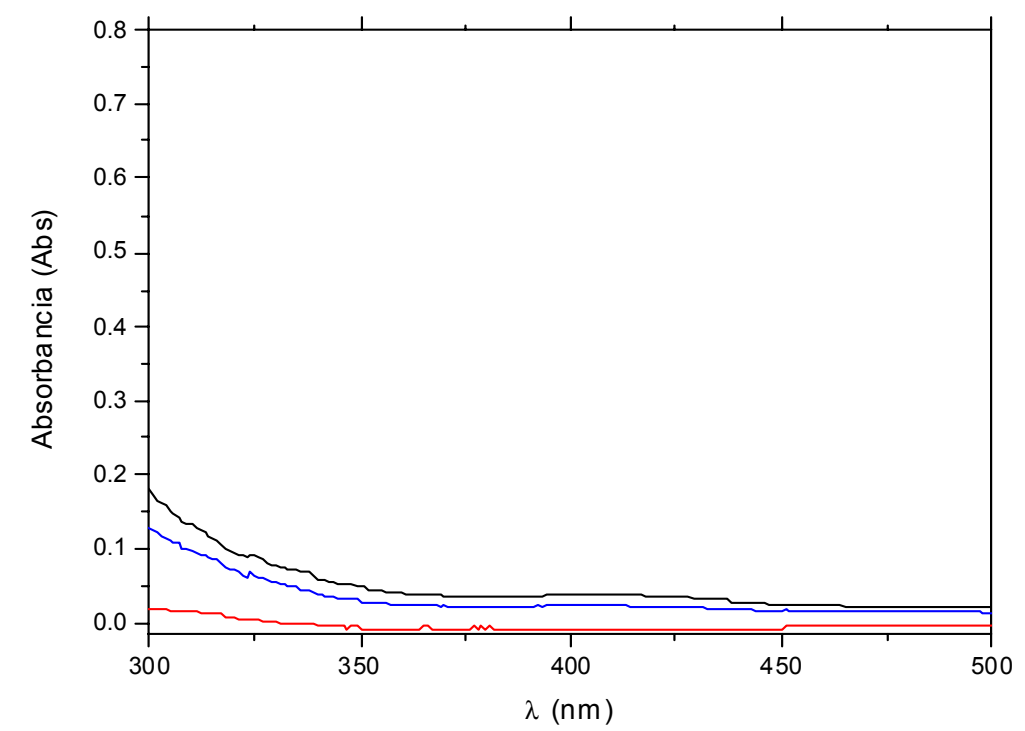

- Espatulação • Tempo de Endurecimento • Extração do Cimento

Figura 19. Espectrograma do cimento endodôntico Endofill nos três momentos analisados.

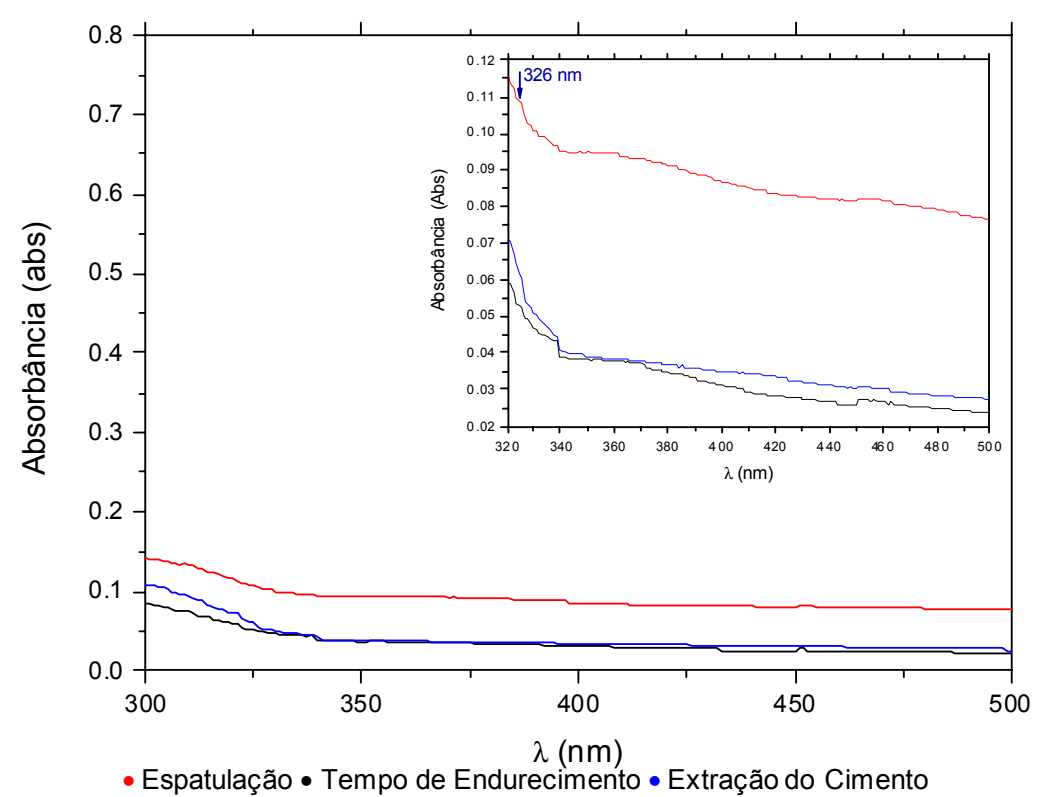

Figura 20. Espectrograma do cimento endodôntico CRCS nos três momentos analisados. 


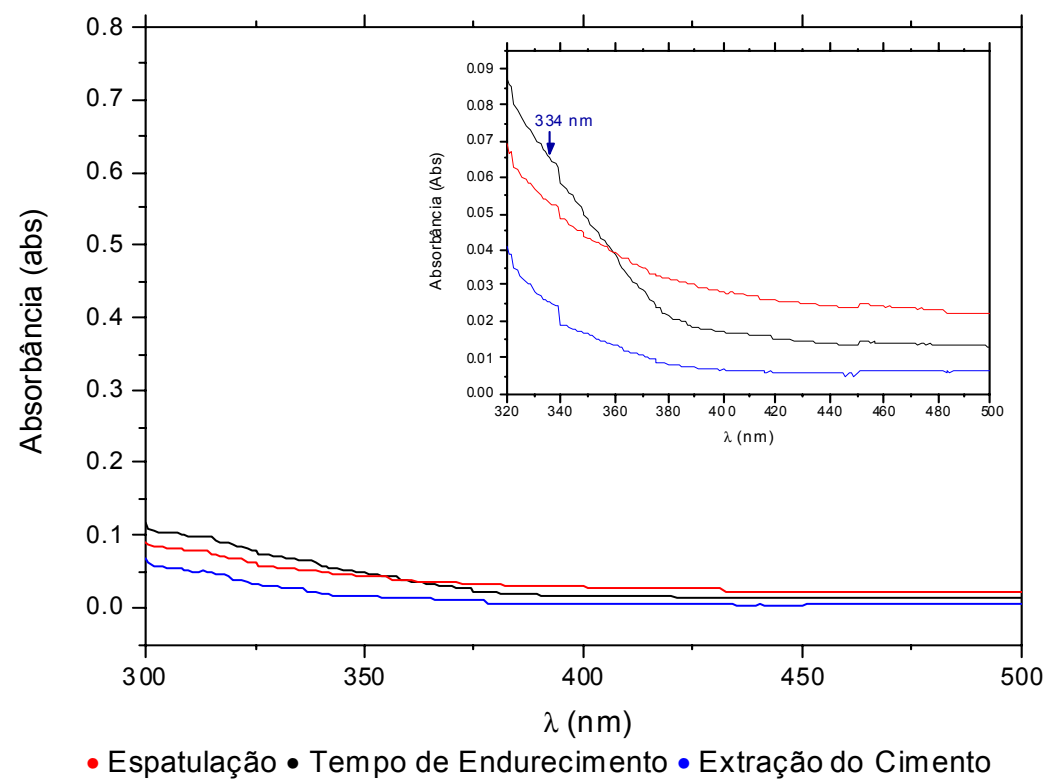

Figura 21. Espectrograma do cimento endodôntico Pulp Canal Sealer nos três momentos analisados.

No caso do cimento Endomèthasone N (Figura 22) detectou-se grande quantidade de formaldeído para os três momentos de análise deste cimento: concentração de $18,14 \mathrm{mg} \cdot \mathrm{L}^{-1}$ na água circundante; $9,43 \mathrm{mg} \cdot \mathrm{L}^{-1}$ na sua massa, extraída pela água; e 9,13 mg. $\mathrm{L}^{-1}$ durante a espatulação, com a liberação total de $36,70 \mathrm{mg} \cdot \mathrm{L}^{-1}$.

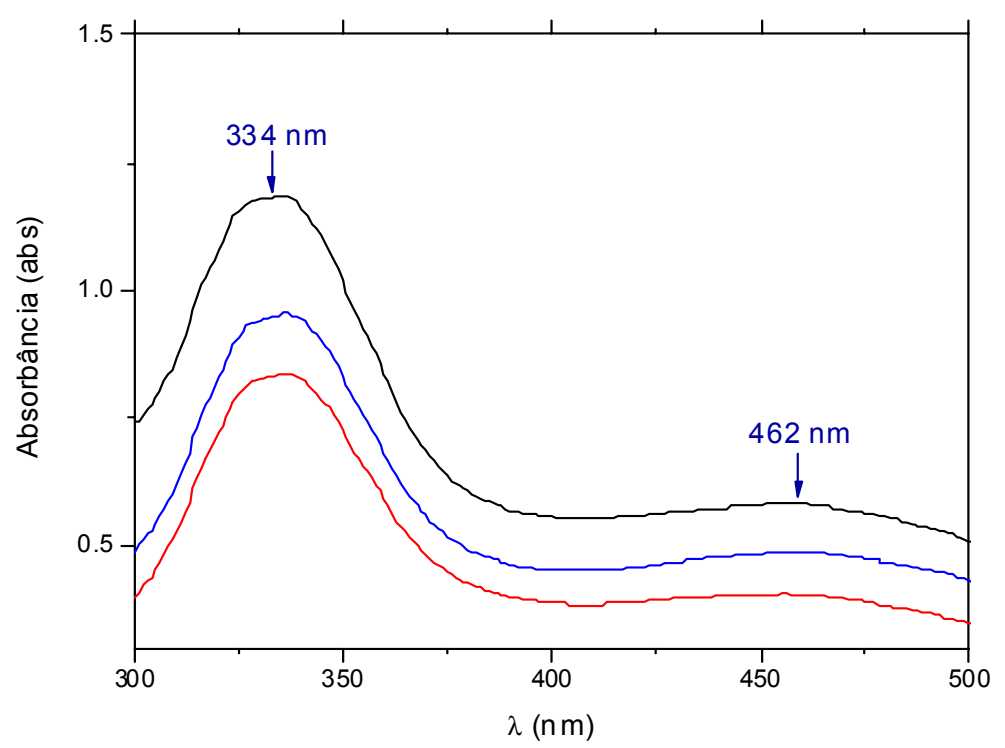

- Espatulação • Tempo de Endurecimento • Extração do Cimento

Figura 22. Espectrograma do cimento endodôntico Endomèthasone $\mathrm{N}$ nos três momentos analisados. 


\subsection{Cimento cerâmico}

Para o cimento BC Sealer (Figura 23) não houve geração de formaldeído nos três momentos analisados.

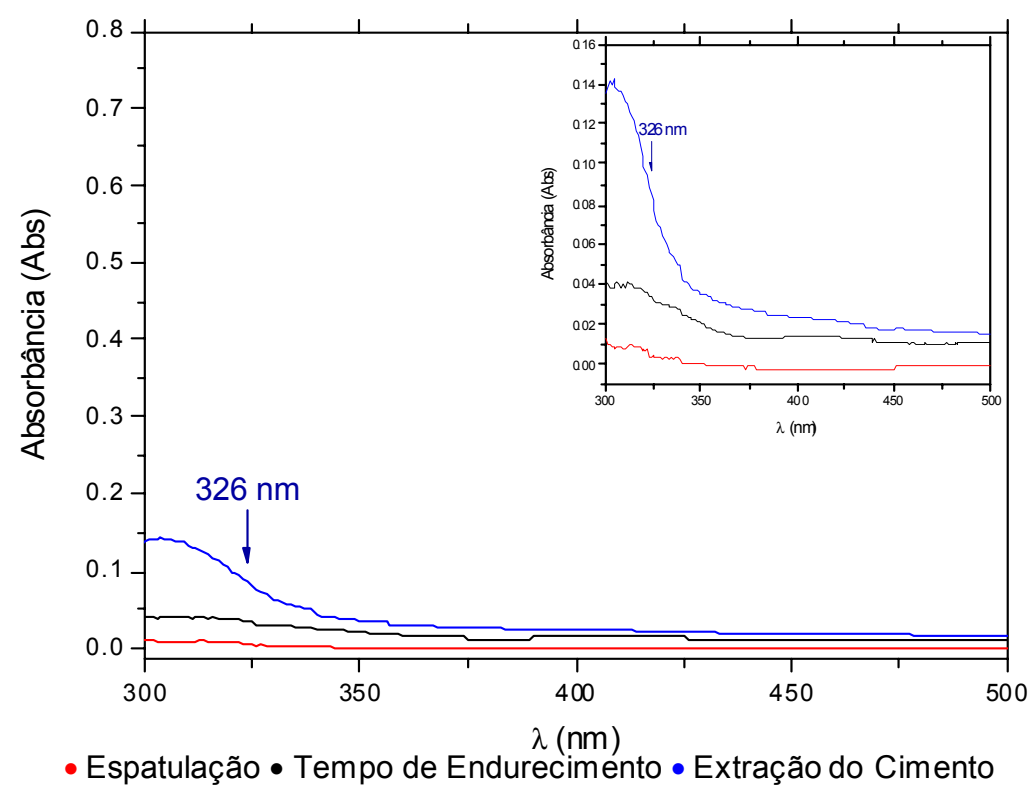

Figura 23. Espectrograma do cimento endodôntico BC Sealer nos três momentos analisados.

Para melhor entendimento dos resultados, na Tabela IV está disposto um sumário dos achados do presente estudo. 
Tabela IV. Quadro de resumo com o teor de formaldeído encontrado nos cimentos analisados. Dados em mg.L-1.

\begin{tabular}{|c|c|c|c|c|}
\hline Ciment & lomento análise & Espatulação & $\begin{array}{l}\text { Lapso de três } \\
\text { vezes o tempo de } \\
\text { endurecimento } \\
\text { do cimento }\end{array}$ & $\begin{array}{c}\text { Após extração } \\
\text { do formaldeído } \\
\text { em água }\end{array}$ \\
\hline 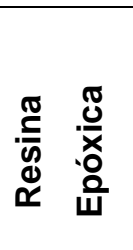 & $\begin{array}{l}\text { AH Plus } \\
\text { Sealer } 26 \\
\text { ThermaSeal Plus }\end{array}$ & $\begin{array}{l}\text { Sim } \\
7.40 \\
\text { Sim }\end{array}$ & $\begin{array}{l}4.44 \\
\text { Sim } \\
\text { Sim }\end{array}$ & $\begin{array}{l}\text { Sim } \\
\text { Sim } \\
\text { Sim }\end{array}$ \\
\hline 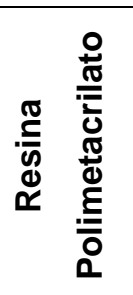 & $\begin{array}{l}\text { Epiphany } \\
\text { MetaSeal } \\
\text { EndoREZ }\end{array}$ & $\begin{array}{l}\text { Não } \\
\text { Não } \\
\text { Sim }\end{array}$ & $\begin{array}{l}\text { Não } \\
\text { Não } \\
\text { Sim }\end{array}$ & $\begin{array}{l}\text { Não } \\
\text { Não } \\
\text { Sim }\end{array}$ \\
\hline $\begin{array}{ll}\frac{0}{0} \\
\frac{0}{0} & 0 \\
\frac{0}{x} & \frac{0}{0} \\
\frac{0}{\pi} & 0 \\
\frac{0}{\frac{0}{1}} & 0\end{array}$ & $\begin{array}{l}\text { Apexit Plus } \\
\text { Sealapex } \\
\text { MTA Fillapex }\end{array}$ & $\begin{array}{l}\text { Não } \\
\text { Não } \\
\text { Não }\end{array}$ & $\begin{array}{l}\text { Não } \\
\text { Não } \\
\text { Não }\end{array}$ & $\begin{array}{l}\text { Não } \\
\text { Não } \\
\text { Não }\end{array}$ \\
\hline 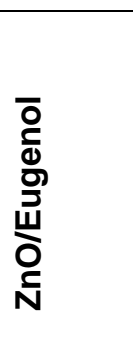 & $\begin{array}{l}\text { Endofill } \\
\text { CRCS } \\
\text { Pulp Canal Sealer } \\
\text { Endomèthasone N }\end{array}$ & $\begin{array}{l}\text { Não } \\
\text { Não } \\
\text { Não } \\
9.13\end{array}$ & $\begin{array}{l}\text { Não } \\
\text { Não } \\
\text { Não } \\
18.14\end{array}$ & $\begin{array}{l}\text { Não } \\
\text { Não } \\
\text { Não } \\
9.43\end{array}$ \\
\hline 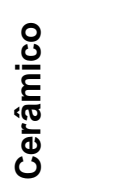 & BC Sealer & Não & Não & Não \\
\hline
\end{tabular}

Obs.: "Sim" = detecção de formaldeído (avaliação qualitativa), porém em quantidade insuficiente para a sua quantificação. "Não" = não detecção de formaldeído 
132 | Resultados 


\section{VI - Discussão}



A presença dos cimentos obturadores na obturação endodôntica (JAINAEN et al., 2007; SOUZA et al. 2009) é requisito necessário para a união dos seus componentes e destes com a dentina (SOUSA-NETO et al. 2002; WHITWORTH, 2005 ). Logo, para o uso endodôntico, devem eles preencher requisitos físicoquímicos e biológicos (ØRSTAVIK et al., 2001) e boa capacidade de vedação (SCHWARTZ, 2006), de modo a permitir o selamento tridimensional do canal radicular (PAWIŃSKA et al., 2011).

Assim, avalia-se a biocompatibilidade dos materiais utilizados, para que tenham aplicação clínica (GEURTSEN; LEYHAUSEN, 1997). Porém, obsevou-se que vários deles liberam formaldeído (GEURTSEN; LEYHAUSEN, 1997), produto químico dotado de características que afetam seriamente a saúde humana (CONAWAY et al, 1996; BINGHAM et al., 2001; KOCH et al., 2001; FRANKS, 2005; IARC, 2006; ORSIÈRE et al., 2006; GOLDSTEIN, 2010; COSTA, 2011; PONGSAVEE, 2011), o que fez com que a American Association of Endodontists, em 1998, publicasse manifestação recomendando que fosse abolido o uso da substância. Todo esse conjunto negativo justifica a realização de estudos como o presente, no sentido de pesquisar a existência do formaldeído nos materiais odontológicos, de modo geral, e endodônticos, particularmente.

Os métodos para a determinação de formaldeído existentes na literatura são os mais diversos e envolvem voltametria por corrente alternada (DEDOV, 2000), potenciometria (KOUPPARIS, 1979), titulometria (HASLAM, 1957), cromatografia gasosa e espectrofotometria (EKBERG, 1966; MILKSCH, 1981, PICKARD, 1984).

Ainda mais, são empregados os métodos titulométricos, que se baseiam em reações envolvendo o grupo carbonílico de aldeídos e cetonas, como é o caso do método do sulfito neutro (FAGNANI et al., 2002), ou que envolvem reações de 
oxidação usando peróxido de hidrogênio, mercurimetria ou iodometria (FAGNANI et al., 2002). Esses métodos têm a desvantagem de não serem seletivos para formaldeído, além de apresentarem limitada sensibilidade. Aplica-se bem a metodologia titulométrica para a padronização de soluções puras, mas para a análise de amostras reais, são necessárias outras técnicas (FAGNANI et al., 2002).

O método espectrofotométrico utilizando dicloreto de parafenilenodiamina em meio tamponado se destaca no contexto analítico por apresentar grande sensibilidade, alta seletividade sendo utilizado para a determinação de formaldeído em soluções e no ar (WEST, 1956), para análises ambientais (OLIVEIRA, 2001) e ocupacionais (WOO,1998), motivos pelos quais, no presente, fez-se a opção pela sua utilização. Baseia-se no efeito catalítico do formaldeído na reação de oxidação entre a parafenilenodiamina eo peróxido de hidrogênio (BAILEY, 1971). O produto da reação de oxidação é um composto de coloração enegrecida que possui absorção por espectrofotometria UV / Vis. Essa reação ocorre numa velocidade muito inferior quando na ausência de formaldeído; por isto, nos primeiros 20 minutos a reação somente ocorre na presença de formaldeído (BAILEY, 1971).

O método colorimétrico de Bailey se destaca por sua alta especificidade em determinação do formaldeído, o que não pode ser dito para os outros métodos, além de sua sensibilidade chegando aos níveis de ppm (partes por milhão) de detecção do formaldeído (SAWICKI, 1963; BAILEY, 1971).

Como os cimentos endodônticos analisados possuem uma grande variedade de componentes (orgânicos e inorgânicos) nas suas formulações podendo atuar como interferentes na análise, o método colorimétrico de Bailey é uma alternativa na obtenção de resultados precisos na detecção de formaldeído (BAILEY, 1971), o que ratifica a opção pela sua escolha no presente estudo. 
A presença do formaldeído ou a liberação dessa substância, após a manipulação de alguns cimentos endodônticos, é relatada na literatura (SPANGBERG et al., 1993; COHEN et al., 1998; KOCH, 1999; LEONARDO et al., 1999; $\mathrm{KOCH}$ et al., 2001), inclusive com destaque para o fato de que a quantidade liberada pelos cimentos endodônticos ser muito maior (SPANGBERG et al., 1993; COHEN et al., 1998; KOCH, 1999; LEONARDO et al., 1999; KOCH et al., 2001), quando comparado às resinas compostas (OYSAED et al., 1988), adesivos para prótese total (EKSTRAND et al., 1993) ou resinas acrílicas para prótese total (RUYTER, 1980). Há que se salientar que, no presente estudo, diferentemente do acima relatado, maiores quantidades de formaldeído foram encontradas quando se analisaram os cimentos resinosos, com exceção do Endomethasone $\mathrm{N}$, que apresentou alto teor dessa substância.

A liberação do formaldeído de cimentos endodônticos foi anteriormente bem aceita por clínicos e pesquisadores, devido ao fato material ser dotado de forte ação antibacteriana (GEURTSEN; LEYHAUSEN, 1997). Entretanto, a eficácia dessa ação, é reputada como baixa e sem proporcionar atuação desejada (BROISMAN et al., 1978, TRONSTAD et al., 1980; GOMES, 2004), fatos que, aliados à toxicidade dessa substância (FORD, 1985; SPANGBERG et al., 1993; CONAWAY et al., 1996; BINGHAM et al., 2001; HUANG et al., 2005; FRANKS, 2005; ØRSTAVIK, 2005; IARC, 2006; ORSIĖRE et al., 2006; HO et al., 2007; BRKIC et al., 2009; ZHANG et al., 2010), não encorajam o seu emprego, justificam o seu banimento (American Association of Endodontists, 1998), bem como o presente estudo.

Os materiais endodônticos podem liberar substâncias imediatamente após sua manipulação, durante o tempo em que está no interior do canal radicular ou em processos de desgaste, erosão e degradação química (LEONARDO et al., 1999; 
$\mathrm{KOCH}$ et al., 2001; BERGER, 2009), motivos pelos quais, no delineamento deste estudo, optou-se pela análise nos diferentes momentos.

O formaldeído em alguns cimentos é liberado devido à presença de hexametilenotetramina (metenamina) no pó (LEONARDO et al., 1999; KOCH et al., 2001). Isso justifica os resultados do presente estudo, em que se encontrou altos teores de formaldeído no cimento Sealer 26, que possui a metenamina na sua composição. Era de se esperar que os cimentos AH Plus ThermaSeal Plus apresentassem o mesmo comportamento, o que, de fato, não ocorreu, e deve ser motivo de investigações posteriores, já que apresentam aminas em sua composição. Explicação provável para o ocorrido se deve à proporção entre os seus componentes quando da espatulação. Maior proporção de pó reduz o total de formaldeído contído, já que aminas compõe a resina. Outra possível explicação é a policondensação de formaldeído, dando origem à resorcina a partir de reação exotérmica. O calor pode levar à maior utilização de formaldeído na formação de resorcina e/ou à sua evaporação (KOCH, 1999).

A formação de formaldeído dentro de um cimento obturador resinoso específico ( $\mathrm{AH}$ 26) é atribuída à hidrólise de hexametilenotetramina (metenamina) em amônia e formaldeído. Essa liberação foi confirmada por outros estudos para o AH 26 (De Trey) (SPANGBERG et al., 1993; LEONARDO et al., 1999). Esse deve ser o motivo pelo qual, o cimento endodôntico híbrido, à base de resina e/ou de hidróxido de cálcio, Sealer 26 também apresentou formaldeído dentro dos resultados deste estudo.

As resinas epóxicas mais utilizadas em cimentos endodônticos são a bisfenol A e a bisfenol F, apresenta a estrutura química de cada um destes compostos (SCORTANU, 1994). Nos cimentos endodônticos a base de resinas epóxi utilizados 
no presente trabalho, os agentes de cura presentes em suas composições são aminas.

A Hexametilenotetramina (HMT) corresponde à amina de cura do cimento Sealer 26. Essa amina é utilizada na manufatura de compostos explosivos, em adesivos, compostos selantes, como fonte de formaldeído. Sua ação antisséptica deve-se ao formaldeído liberado após hidrólise ácida da hexametilenotetramina, segundo a reação abaixo (TININIS et al. 2001):

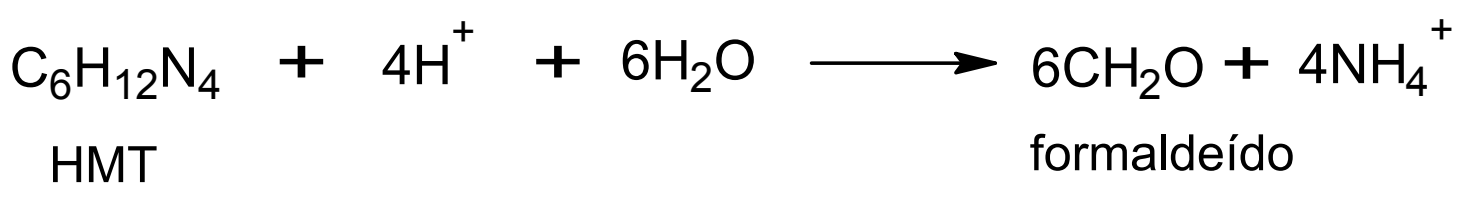

O cimento que apresentou maior quantidade de formaldeído liberado dentro deste grupo foi o Sealer 26 durante o tempo de espatulação $\left(7,40 \mathrm{mg} \cdot \mathrm{L}^{-1}\right)$ seguido do $\mathrm{AH}$ Plus que liberou (4.44 $\left.\mathrm{mg} . \mathrm{L}^{-1}\right)$ durante o tempo de endurecimento. Estes valores estão muito acima do limite máximo de $0.1 \mathrm{ppm} / 15 \mathrm{M}$ recomendado pelo National Institute for Occupational Safety and Health (NIOSH) (INCA, 2011), porém dentro do limite máximo permitido de exposição contínua que é de 5 ppm, sendo que, nos casos de pico, a concentração máxima deve ser de 10 ppm segundo Occupational Health and Safety Assessment Services OSHA (2011).

A geração de formaldeído no cimento endodôntico Sealer 26 está diretamente ligada à quantidade de HMT que se hidrolisa, em detrimento a isto, o formol produzido será proporcional à quantidade da base sólida (pó), agregada à base líquida durante a espatulação (TININIS et al. 2001). 
Tanto o Therma Seal quanto o AH Plus possuem em sua composição as resinas à base de monômeros bisfenol (A e F) polimerizadas por aminas (dibenzildiamina, aminoadamantano e triciclodecano-diamina) (Figura 24).

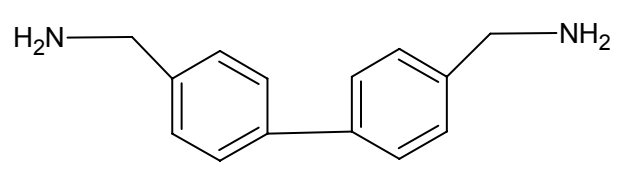

biphenyl-4,4'-diyldimethanamine

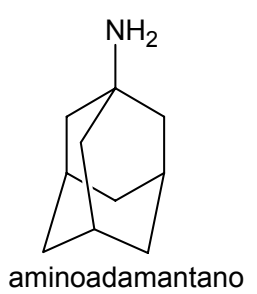

Figura 24 - Aminas utilizadas na cura dos cimentos endodônticos Therma Seal e AH Plus.

A hidrólise das aminas presentes na pasta dos cimentos Therma Seal e $\mathrm{AH}$ Plus produzem amônia e formaldeído como produtos desta reação.

A diferença das quantidades liberadas de formaldeído para os dois cimentos pode ser explicada por variações quantitativas das aminas presentes na pasta destes dois cimentos. Também é possível que a geração de formaldeído esteja vinculada a um período maior que seis meses de armazenamento do produto, como salientado por $\mathrm{KOCH}$ et al. (2001) em relação ao cimento AH26, composto por aminas metanoaminas como agente de cura.

Ao analisar os cimentos do grupo polimetacrilato, pode-se observar pequena liberação de formaldeído (traços) para o Endorez. O fabricante não fornece sua formulação exata; cita apenas que é um selante/enchimento de canais radiculares biocompatível, à base de metacrilato. Em função da falta de dados de composição, fica impossível associar a geração de formaldeído a algum componente seu.

Os cimentos à base de Hidróxido de Cálcio não apresentaram formaldeído em nenhum momento analisado. Isso pode ser justificado por suas formulações serem 
baseadas em componentes inorgânicos (hidróxido e óxido de cálcio), responsáveis pelos seus endurecimentos.

A quantidade de materiais orgânicos (resinas) presente é pequena, e atuam como modificadores das propriedades físicas (elasticidade, endurecimento, solubilidade, tempo de endurecimento, etc).

Nos cimentos Endofill, CRCS e Pulp Canal Sealer, não se observou a presença de formaldeído. Isso pode ser facilmente explicado, uma vez que os elementos que compõem sua base (ZnO/Eugenol) se unem por reação de quelação, dando a formação de eugenolato de zinco (OZE).

Apenas no cimento Endomèthasone $\mathrm{N}$ foi detectada a liberação de formaldeído, no total de $36,70 \mathrm{mg} \cdot \mathrm{L}^{-1}$. Apresentava formaldeído na sua composição (GEURTSEN; LEYHAUSEN, 1997). Atualmente, segundo o fabricante, a substância foi dele removida (GOMES et al. 2004), dando origem à denominação Endomèthasone N. Não obstante essa informação, esse cimento apresentou altos valores de liberação da substância nos três momentos de estudo deste.

Tendo como verdadeira a afirmação do fabricante do produto, a explicação para o fato seria a de que a substância encontrada fosse subproduto da reação de endurecimento do material, da mesma forma como ocorre com aqueles à base de resina (SPANGBERG et al., 1993; KOCH, 1999).

Não se detectou formaldeído durante os três momentos analisados para o cimento BC Sealer. Cerâmico, sua base é constituída basicamente por compostos inorgânicos e uma pequena quantidade de agentes espessantes (não especificados na formulação) (LOUSHINE et al., 2011).

A escolha da água como adsorvente para o formaldeído se deu em razão das propriedades de interação entre estes compostos, já que o formaldeído dissolve-se 
facilmente na água (KUMPF; DAMEWOOD, 1989). Foi preciso então determinar a capacidade de coleta do formaldeído na metodologia proposta, motivo pelo qual se realizaram testes utilizando uma solução de formaldeído com concentração 10,0 $\mathrm{mg} \cdot \mathrm{L}^{-1}$, correspondente ao valor médio da curva de calibração utilizada na determinação do formaldeído, conforme os critérios utilizados na metodologia.

A busca de novos materiais não cessa. Porém, deve ela ser sempre norteada por princípios que contemplem as excelentes propriedades físico-químicas dos materiais, associadas à biocompatibilidade adequada e desejada, de modo que o tratamento endodôntico consiga alcançar a finalidade a que se destina. 


\section{VII - Conclusões}



Diante da metodologia empregada e com base nos resultados obtidos e tendo como base os momentos de análise do teor de formaldeído liberado pelos cimentos avaliados, foi possível concluir que:

1- Durante a espatulação dos cimentos, todos aqueles à base de resina epóxica liberaram formaldeído, porém a quantificação ocorreu apenas em relação ao Sealer 26;

1.1- $\mathrm{O}$ cimento Endomèthasone $\mathrm{N}$ apresentou a maior quantidade de formaldeído, e o Endorez liberou a substância, porém em quantidade insuficiente para a sua quantificação;

2- Noutra oportunidade, delimitada como sendo após a espatulação até o tempo correspondente a três vezes o tempo de endurecimento do material avaliado, todos aqueles à base de resina epóxica liberaram formaldeído, porém a quantificação ocorreu apenas em relação ao AH Plus;

2.1- $\mathrm{O}$ cimento Endomèthasone $\mathrm{N}$ apresentou a maior quantidade de formaldeído, e o Endorez liberou a substância, porém em quantidade insuficiente para a sua quantificação;

3- Quando da extração do formaldeído da massa endurecida, todos os cimentos à base de resina epóxica e o Endorez liberaram formaldeído em quantidade insuficiente para a sua quantificação, e o cimento Endomèthasone $\mathrm{N}$ liberou a maior quantidade dessa substância. 
146 | Conclusões 


\section{VIII - Referências Bibliográficas}



AL-HIYASAT, A. S.; TAYYAR, M.; DARMANI, H. Cytotoxicity evaluation of various resin based root canal sealers. Int Endod J., v. 43, n. 2, p. 148-153, 2010.

ARI, H.; BELLI, S.; GUNES, B. Sealing ability of Hybrid Root SEAL (MetaSeal) in conjunction with different obturation techniques. Oral Surg. Oral Med. Oral. Pathol. Oral Radiol. Endod., v. 109, n. 6, p. e113-e116, 2010.

BAILEY, B.W.; RANKIN, J. M. New spectrophotometric method for determination of formaldehyde. Anal Chem., v. 43, n. 6, p. 782-784,1971.

BERGER, C. R. Analise da composição inorgânica e da liberação de formaldeído após a manipulação de cimentos endodônticos. 2009. 112p.Tese (Doutorado em Endodontia - Faculdade de Odontologia de Piracicaba. Universidade Estadual de Campinas. UNICAMP.

BERNÁTH, M.; SZABÓ J. Tissue reaction initiated by different sealers. Int Endod J., v. 36, n. 4, p. 256-261, 2003.

BERTRAM, J. S. The molecular biology of cancer. Mol Aspects Med., v. 21, n. 6, p. 167-223, 2000.

BINGHAM, E.; COHRSSEN, B.; POWELL, C.H.; Patty's Toxicology Volumes 1-9 5th ed. 2001.. New York, N.Y: p. 5-987, John Wiley \& Sons.

BOJ, J. R.; MARCO, I.; CORTÉS, O.; CANALD, C. The acute nephrotocity of systemically administered formaldehyde in rats. Eur J Paediatr Dent, v. 4, n. 1, p. 16-20, 2003.

BOUILLAGUET, S.; WATAHA, J. C.; LOCKWOOD, P. E.; GALGANO, C.; GOLAY, A.; KREJCl, I. Cytotoxicity and sealing properties of four classes of endodontic sealers evaluated by succinic dehydrogenase activity and confocal laser scanning microscopy. Eur J Oral Sci. v. 112, n. 2, p. 182-187, 2004.

BOUILLAGUET, S.; WATAHA, J. C.; TAY, F. R.; BRACKETT, M. G.; LOCKWOOD, P. E. Initial in vitro biological response to contemporary endodontic sealers. J Endod., v. 32, n. 10, p. 989-992, 2006.

BROISMAN, H.; VAN HOUTE, J.; GRON, P.; KRAKOW, A. A. Antimicrobial effects of N2 in vitro. Oral Surg Oral Med Oral Pathol, v. 45, p. 116-122, 1978. 
BRKIĆ, A.; GÜRKAN-KÖSEOĞLU, B.; OLGAC, V. Surgical approach to iatrogenic complications of endodontic therapy: a report of 2 cases. Oral Surg Oral Med Oral Pathol Oral Radiol Endod. V. 107, n. 5, p. 50-53, 2009.

CANOVA, G. C.; TAVEIRA, L. A. A.; DEZAN JUNIOR, E.; NISHIYAMA, C. K.; SPALDING, M. Estudo do poder flogógeno de quatro cimentos obturadores de canais radiculares por meio do teste edemogênico. Rev Fac Odontol Bauru, v. 10, n. 3, p. 128-133, 2002.

CHANDRASEKHAR V, MORISHETTY PK, METLA SL, RAJU RV. Expansion of gutta-percha in contact with various concentrations of zinc oxide-eugenol sealer: a three-dimensional volumetric study. J Endod., v. 37, n. 5, p. 697-700, 2011.

COHEN, B.I.; PAGNILLO MK, MUSIKANT BL, DEUTSCH AS. Formaldehyde evaluation from endodontic materials. Oral Health., v. 88, n. 12, p. 37-39, 1998.

CONAWAY, C. C.; WHYSNER, J.; VERNA, L. K.; WILLIAMS, G. M. Formaldehyde mechanistics data and risk assessment: endogenous protection from DNA adduct and formation. Pharmacology \& Therapeutics, v. 71, n. 2, p. 29-55, 1996.

CORTÉS, O.; FERNANDEZ, J.; BOJ, J. R.; CANALDA, C. Effect of formaldehyde on rat liver in doses used in pulpotomies. J Clin Pediatr Dent., v. 31, n. 3, p. 179-182, 2007.

COSTA, S.; PINA, C.; COELHO, P.; COSTA, C.; SILVA, S.; PORTO, B.; LAFFON, B.; TEIXEIRA, J. P. Occupational exposure to formaldehyde: genotoxic risk evaluation by comet assay and micronucleus test using human peripheral lymphocytes. Toxicol Environ Health A., v. 74, n. 15-16, p. 1040-1051, 2011.

DE DEUS, Q. D. Frequency, location, and direction of the lateral, secondary, and accessory canals. J Endod., v. 1, n. 11, p. 361-366, 1975.

DEDOV, A. G. Indirect determination of formaldehyde by alternating-current voltammetry at a hanging mercury drop in the presence of oxygen. J. Anal. Chem., v. 55 , p. 583-585, 2000.

DONGARI, A.; LAMBRIANIDIS T. Periodontally derived pulpal lesions. Endod Dent Traumatol., v. 4, n. 2, p. 49-54,1988.

DUONG, A.; STEINMAUS, C.; MCHALE, C. M.; VAUGHAN, C. P.; ZHANG, L. Reproductive and developmental toxicity of formaldehyde: a systematic review. Mutat Res., v. 728, n. 3, p. 118-3820, 2011. 
EKBERG, D. R.; SILVER, E. C. Rapid spectrophotometric method for formaldehyde detection. Anal. Chem., v. 38, p. 1421-1422, 1966.

EKSTRAND, K.; HENSTEN-PETTERSEN, A.; KULLMANN, A. Denture adhesives: cytotoxicity, microbial contamination, and formaldehyde content. J Prosthet Dent., v. 69, p. 314-317, 1993.

ERSEV, H.; SCHMALZ, G.; BAYIRLI, G.; SCHWEIKL, H. Cytotoxic and mutagenic potencies of various root canal filling materials in eukaryotic and prokaryotic cells in vitro. J Endod., v. 25, n. 5, p. 359-363, 1999.

FAGNANI, E.; MELIOS, C. B.; PEZZA, L.; PEZZA, H. R. Development of spectrophotometric method for the analysis of paraformaldehyde in commercial and industrial disinfectants. Ecl. Quím. (São Paulo), v. 27, 2002.

FRANKS, S. J. A Mathematical model for the absorption and metabolism of formaldehyde vapour by humans. Toxicology and Applied Pharmacology, v. 206, n. 3, p. 309-320, 2005.

GATEWOOD, R. S. Endodontic materials. Dent Clin North Am., v. 51, n. 3, p. 695712, 2007.

GEURTSEN, W.; LEYHAUSEN, G. Biological aspects of root canal filling materialshistocompatibility, cytotoxicity, and mutagenicity. Clin Oral Investig., v. 1, n. 1, p. 5$11,1997$.

GIOVANINI, A. F.; LEONARDI, D. P.; BARATTO-FILHO, F.; VLENÇA, P. C.; MORESCA, R. C.; MORO, A.; SCHRAMM, C. A. An endodontic sealer induces a pathological condition when associated with persistent tissue toxicity and presence of myofibroblasts. Braz Dent J., v. 22, n. 5, p. 369-76, 2011.

GOLDSTEIN, B. D. Hematological and toxicological evaluation of formaldehyde as a potential cause of human leukemia. Hum Exp Toxicol., v. 30, n. 7, p. 725-735, 2011.

GOMES, B. P. F. A. ; PEDROSO, J. A.; JACINTO, R. C.; VIANNA, M. E.; FERRAZ, C. C. R.; ZAIA A. A.; SOUZA-FILHO, F. J. In vitro evaluation of the antimicrobial activity of five root canal sealers. Braz Dent J., v. 15, n. 1, p. 30-35, 2004.

HAÏKEL, Y.; BRAUN, J. J.; ZANA, H.; BOUKARI, A.; DE BLAY, F.; PAULI, G. Anaphylactic shock during endodontic treatment due to allergy to formaldehyde in a root canal sealant. J Endod., v. 26, n. 9, p. 529-531, 2000. 
HAUMAN, C. H.; LOVE, R. M. Biocompatibility of dental materials used in contemporary endodontic therapy: a review. Part 2. Root-canal-filling materials. Int Endod J., v. 36, n. 3, p, 147-160, 2003.

HAUPTMANN, M.; LUBIN, J. H.; STEWART, P. A.; HAYES ,R. B.; BLAIR A. Mortality from solid cancers among workers in formaldehyde industries. Am J Epidemiol., v. 159, n. 12, p. 1117-1130, 2004.

HO, Y. C.; HUANG, F. M.; CHANG, Y. C. Cytotoxicity of formaldehyde on human osteoblastic cells is related to intracellular glutathione levels. J Biomed Mater Res B Appl Biomater., v. 83, n. 2, p. 340-344, 2007.

HUANG, F. M.; CHOU, L. S.; CHOU, M. Y.; CHANG, Y. C. Protective effect of NAC on formaldehyde-containing-ZOE-based root-canal-sealers-induced cyclooxygenase2 expression and cytotoxicity in human osteoblastic cells. J Biomed Mater Res B Appl Biomater., v. 74, n. 2, p. 768-773, 2005.

HUANG, F. M.; HSIEH, Y. S.; TAI, K. W.; CHOU, M. Y.; CHANG, Y. C. Induction of cfos and c-jun protooncogenes expression by formaldehyde-releasing and epoxy resin-based root-canal sealers in human osteoblastic cells. J Biomed Mater Res., v. 59, n. 5, p. 460-465, 2002.

HUANG, F. M.; TAI, K. W.; CHOU, M. Y.; CHANG, Y. C. Cytotoxicity of resin-, zinc oxide-eugenol-, and calcium hydroxide-based root canal sealers on human periodontal ligament cells and permanent V79 cells. Int Endod J., v.35, n. 2, p 153158, 2002.

HUANG, F. M.; YANG, S. F.; CHANG, Y. C. Up-regulation of gelatinases and tissue type plasminogen activator by root canal sealers in human osteoblastic cells. J Endod., v. 34, n. 3, p. 291-294, 2008.

HUANG, T. H.; LII, C. K.; CHOU, M. Y.; KAO, C. T. Lactate dehydrogenase leakage of hepatocytes with AH26 and AH Plus sealer treatments. J Endod., v. 26, n. 9, p, 509-511, 2000.

HASLAM, J.; SQUIRRELL, D. C. M. Further observations on automatic titrimetry. Analyst, v. 82, p. 511-517, 1957.

IARC. International Agency for Research on Cancer: Formaldehyde, 2butoxyethanol, and 1-tertbutoxy-2propanol. Monogr Eval Carcinog Risks Hum., v. 88, p. 39-325, 2006. 
JACK, R. M.; GOODELL, G. G. In vitro comparison of coronal microleakage between Resilon alone and gutta-percha with a glass-ionomer intraorifice barrier using a fluid filtration model. J Endod., v. 34, n. 6, p. 718-720, 2008.

JAINAEN, A.; PALAMARA, J. E.; MESSER, H. H. Push-out bond strengths of the dentine-sealer interface with and without a main cone. Int Endod J., v. 40, n. 11, p. 882-890, 2007.

KAPLAN, A. E.; ORMAECHEA, M. F.; PICCA, M.; CANZOBRE, M. C.; UBIOS, A. M. Rheological properties and biocompatibility of endodontic sealer. Int Endod J.; v. 6, n. 8, p. 527-532, 2003.

KARAPINAR-KAZANDAĞ, M.; BAYRAK, O. F.; YALVAÇ, M. E.; ERSEV, H.; TANALP, J.; SAHIN, F.; BAYIRLI, G. Cytotoxicity of 5 endodontic sealers on L929 cell line and human dental pulp cells. Int Endod J., v. 44, n. 7, p. 626-634, 2011.

KOAGEL, S. O.; MINES, P.; APICELLA, M.; SWEET, M. In vitro study to compare the coronal microleakage of Tempit UltraF, Tempit, IRM, and Cavit by using the fluid transport model. J Endod., v. 34, n. 4, p. 442-444, 2008.

$\mathrm{KOCH}, \mathrm{M}$. J. Formaldehyde release from root-canal sealers: influence of method. Int Endod J.,v. 32, n. 1, p.10-6, 1999.

KOCH, M. J; WUNSTEL, E.; DIPI-ING, F. H; STEIN, G. Formaldehyde release from ground root canal sealer in vitro. J Endod.; v. 27, n. 6, p. 396-400, 2001.

KOPPER, P. M. P.; TARTAROTTI, E.; PEREIRA, C. C.; FIGUEIREDO, J. A. P. Estudo da padronização de cones de guta-percha de três marcas comerciais. RGO, v. 55, n. 2, p. 123-126, 2007.

KOSEOGLU, B. G.; TANRIKULU, S.; SUBAY, R. K; SENCER, S. Anesthesia following of a root canal sealer in the mandibular canal: a case report. Oral Surg Oral Med Oral Pathol Oral Radiol Endod., v. 101, n. 6, p. 803-806, 2006.

KOUPPARIS, M. A.; EFSTATHIOU, C. E.; HADJIIOANNOU, P. Kinetic determination of formaldehyde and hexamethylenetetramine with a cyanide-selective electrode. Anal. Chim. Acta, v. 107, p. 91-100, 1979.

KIM, Y. K. ; GRANDINI, S.; AMES, J. M.; GU L. S.; KIM, S. K.; PASHLEY, D. H.; GUTMANN, J. L.; TAY, F. R. Critical review on methacrylate resin-based root canal sealers. J Endod., v. 36, n. 3, p. 383-399, 2010. 
KUMPF, A. R.; DAMEWOOD, JR. J. R. Interaction of formaldehyde with water. J. Phys. Chem., v. 93, n. 11, p. 4478-4486, 1989.

LEE, K. W.; WILLIAMS, M. C.; CAMPS, J. J.; PASHLEY, D. H. Adhesion of endodontic sealers to dentin and gutta-percha. J Endod., v. 28, n. 10, p. 684-688, 2002.

LEONARDO, M. R.; DA SILVA, L. A. B.; TANOMARU, M.; SANTANA, R. Release of formaldehyde by 4 endodontic sealers. Oral Surg Oral Med Oral Pathol Oral Radiol Endod., v. 88, n. 2, p. 221-225, 1999.

LEYHAUSEN, G.; HEIL, J.; REIFFERSCHEID, G.; WALDMANN, P.; GEURSTSEN, W. Genotoxicity and citotoxicity of the epoxy resin-based root canal sealer AH Plus. J Endod., v. 25, n. 2, p. 109-113, 1999.

LOUSHINE, B. A.; BRYAN, T. E.; LOONEY, S. W.; GILLEN, B. M.; LOUSHINE, R. J.; WELLER, R. N.; PASHLEY, D. H.; TAY, F. R. Setting properties and cytotoxicity evaluation of a premixed bioceramic root canal sealer. J Endod., v. 37, n. 5, p. 673677, 2011.

LOVSCHALL, H.; EISKJAER, M.; ARENHOLT-BINDSLEY, D. Formaldehyde cytotoxicity in three human cell types assessed in three different assays. Toxicol In Vitro., v. 16, n. 1, p. 63-69, 2002.

MAZINIS, E.; ELIADES, G.; LAMBRIANIDES, T. An FTIR study of the setting reaction of various endodontic sealers. J Endod., v. 33, n. 5, p. 616-620, 2007

MILETIC, I.; JUKIC, S.; ANIC, D.; ZELJEZIC, V.; GARAJ-WRHOVAC, V.; OSMAK, M. Examination of cytotoxicity and mutagenicity of AH26 and AHPlus sealers. Int Endod J.; v. 36, n. 5, p. 330-335, 2003.

MILKSCH, R. R. Modified pararosaniline meted for the determination of formaldehyde in air. Anal. Chem., v. 53, p. 2118-2123, 1981.

MJÖR, I. A.; PINDBORG J. J. Histology of the human tooth. Munksgaard,1973. Copenhagen.

MURPHY, W. M. The testing of endodontic materials in vitro. Int Endod J., v. 21, p. 170-177, 1988.

NAIR, C. P. R. Advances in addition-cure phenolic resins, Progress in Polymer Science, v. 29, n. 5, p. 401-498, 2004. 
NGUYEN, NT. Obturation of the root canal system. In: Cohen S, Burns R. Pathways of the pulp. $6^{a}$ ed., 1994 Saint Louis: p.193-280, Mosby.

OLIVEIRA, S. V. W. B. Avaliação da degradação e toxicidade de formaldeído em reator anaeróbio horizontal de leito fixo. 2001. 95p. Dissertação (Mestrado em Hidráulica e Saneamento) - Escola de Engenharia de São Carlos da Universidade de São Paulo, São Carlos, 2001.

ORSIĖRE, T.; SARI-MINODIER, I.; IARMARCOVAI, G.; BOTTA, A. Genotoxic risk assessment of pathology and anatomy laboratory workers exposed to formaldehyde by use of personal air sampling and analysis of DNA damage in peripheral lymphocytes. Mutat Res., v. 605, p. 30-41, 2006.

ØRSTAVIK, D. Materials used for root canal obturation: technical, biological and clinical testing. Endod pics., v.12, p. 25-38, 2005.

ØRSTAVIK, D.; NORDAHL, I.; TIBBALLS, J. E. Dimensional change following setting of root canal sealer materials. Dent Mater., v. 17, n. 6, p. 512-59, 2001.

OYSAED, H.; RUYTER, I. E.; SJOVIK, K. I. J. Release of formaldehyde from dental composites. J Dent Res, v. 67, p. 1289-1294, 1988.

PAWIŃSKA, M.; KIERKLO, A.; TOKAJUK, G.; SIDUN, J. New endodontic obturation systems and their interfacial bond strength with intraradicular dentine - ex vivo studies. Adv Med Sci., V. 56, n. 2, p. 327-333. 2011.

PICKARD, A. D.; CLARK, E. R. The determination of traces of formaldehyde. Talanta, v. 31, p. 763-771, 1984.

PINEDA, A. R. P.; RIBEIRO, A. G. C. S.; ALBERGARIA, S. J. Avaliação da infiltração apical nas obturações de canais radiculares preparados com uma técnica manual e outra rotatória. Rev. Ciênc. Méd. Biol., v. 4, n. 3, p. 208-213, 2005.

PITT, FORD T. R. Tissue reactions to two root canal sealers containing formaldehyde. Oral Surg Oral Med Oral Pathol., v. 60, n. 6, p. 661-65, 1985.

PONGSAVEE, M. In vitro study of lymphocyte antiproliferation and cytogenetic effect by occupational formaldehyde exposure. Toxicol Ind Health., v. 27, n. 8, p. 719-723. 2011.

RUYTER, I. E. Release of formaldehyde from denture base polymers. Acta Odontol Scand, v. 33, p. 17-27, 1980. 
SAWICKI, E.; STANLEY, T. W.; PFAFF, J., Anal. Chim. Acta, v. 28, p. 156, 1963.

SCHILDER H. Filling root canals in three dimensions. Dent Clin North Am., v. 1, p. 723-744, 1967.

SCHILDER H. Filling root canals in three dimensions. 1967. J Endod., v. 32, n. 4, p. 281-290, 2006.

SOUSA-NETO, M. D.; MARCHESAN, M. A.; PÉCORA, J. D.; JUNIOR, A. B.; SILVASOUSA, Y. T.; SAQUY, P. C. Effect of Er:YAG laser on adhesion of root canal sealers. J Endod., v. 28, n. 3, p. 185-187, 2002.

SOUZA, E. M.; WU, M. K.; SLUIS, L. W. VAN DER; LEORNARDO, R. T.; BONETTIFILHO, I.; WESSELINK, P. R. Effect of filling technique and root canal area on the percentage of gutta-percha in laterally compacted root fillings. Int. Endod. J., v. 42, n. 8, p. 719-726, 2009.

SCHWANDT, N. W.; GOUND, T. G. Resorcinol-formaldehyde resin "Russian Red" endodontic therapy. J Endod., v. 29, n. 7, p. 435-437, 2003.

SCHWARTZ, R. R. Adhesive dentistry and Endodontics. Part 2: bonding in the root canal system - the promise and the problems: a review. J Endod., v. 32, n. 12, p. 1125-1134, 2006.

SCHWARZE, T.; FIEDLER, I.; LEYHAUSEN, G.; GEURTSEN, W. The cellular compatibility of five endodontic sealers during the setting period. J Endod., v. 28, n. 11, p. 784-786, 2002.

SCHWARZE, T.; LEYHAUSEN, G.; GEURTSEN, W. Long-term cytocompatibility of various endodontic sealers using a new root canal model. J Endod., v. 28, n. 11, p. 749-753, 2002.

SPANGBERG, L. S. W.; BARBOSA, S. V.; LAVIGNE, G. D. AH 26 releases formaldehyde. J. Endod., v. 19, n. 12, p. 596-598, 1993.

SWENBERG, J. A; KERNS, W. D.; MITCHEL, R. J.; GRALIA, E.; PAVKOV, K. L. Induction of squamous cell carcinome of the rat nasal cavity by inhalation exposure to formaldehyde vapor. Cancer Res., v. 40, n. 9, p. 3398-3402, 1980.

TAI, K. W.; HUANG, F. M; HUANG, M. S.; CHANG, Y. C. Assessment of the genotoxicity of resin and zinc-oxide eugenol-based root canal sealers using an in vitro mammalian test system. J Biomed Mater Res., v. 14, n. 59, p. 73-77, 2002. 
TININIS, A. G. Desenvolvimento de metodologia simplificada para análise de hexametilenotetramina (hmt) em medicamentos contendo corantes em sua formulação. Eclet. Quím., v. 26, p. 175-184, 2001

TRONSTADT, L.; WENNBERG, A. In vitro assessment of the toxicity of filling materials. Int Endod J, v. 13, p. 131-138, 1980.

VERCO, P. J. W. Microbiological effectiveness of a reduced concentration of Buckley's formocresol. Pediatr Dent., v. 7, n. 2, p. 130-133, 1985.

WALTIMO, T. M.; BOIESEN, J.; ERIKSEN, H. M.; ØRSTAVIK, D. Clinical performance of 3 endodontic sealers. Oral Surg Oral Med Oral Pathol Oral Radiol Endod., v. 92, n. 1, p. 89-92, 2001.

WEST, P. W.; SEN, B. Spectrophotometric determination of traces of formaldehyde. Fresenius Z. Anal. Chem., v. 153, p. 177-183, 1956.

WHITWORTH, J. Methods of filling root canals: principles and practice. Endo Topics, 212-224. 2005.

WILLEMSEN, W. L.; SIERS, M. L. Formaldehyde in dental materials. Ned Tijdschr Tandheelkd., v. 106, n. 8, p. 295-297, 1999.

WOO, C. S.; BARRY, S. E.; ZAROMB, S. Detection and estimation of part-per billion levels of formaldehyde using a portable high-throughput liquid absorption air sampler. Environ. Sci. Technol., v .32, p. 169-176, 1998.

WU, M. K.; DUMMER, P. M. H.; WESSELINK, P.R. Consequences of and strategies to deal with residual post-treatment root canal infection. Int. Endod. J., v. 39, n. 35, p. 343-356, 2006.

YATSUHASHI, T.; NAKAGAWA, K.; MATSUMOTO, M.; KASAHARA, M.; IGARASHI, T.; ICHINOHE, T.; et al. Bull Tokyo Dent Coll., v. 44, n. 4, p. 209-212, 2003.

ZHANG, L.; TANG, X.; ROTHMAN, N.; VERMEULEN, R.; JI, Z.; SHEN, M.; QIU, C.; GUO, W.; LIU, S.; REISS, B.; FREEMAN, L. B.; GE, Y.; HUBBARD, A. E.; HUA, M.; BLAIR, A.; GALVAN, N.; RUAN, X.; ALTER, B. P.; XIN, K. X.; LI, S.; MOORE, L. E.; KIM, S.; XIE, Y.; HAYES, R. B.; AZUMA, M.; HAUPTMANN, M.; XIONG, J.; STEWART, P.; LI, L.; RAPPAPORT, S. M; HUANG, H.; FRAUMENI, JF, J. R.; SMITH, M. T.; LAN, Q. Occupational exposure to formaldehyde, hematotoxicity, and leukemia-specific chromosome changes in cultured myeloid progenitor cells. Cancer Epidemiol Biomarkers Prev.,v. 19, n. 1, p. 80-88, 2010. 